General Geology of the Hahns Peak and Farwell Mountain Quadrangles, Routt County, Colorado

G E O L O G I CA L S U R V E Y B U L L E T I N 1349

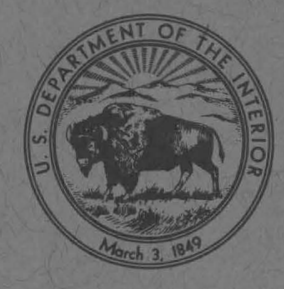




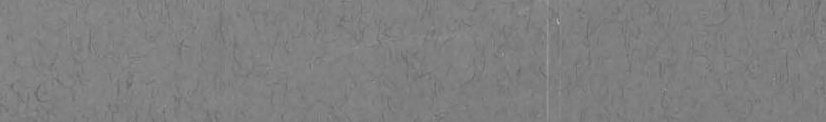

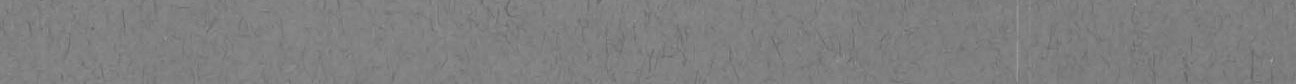

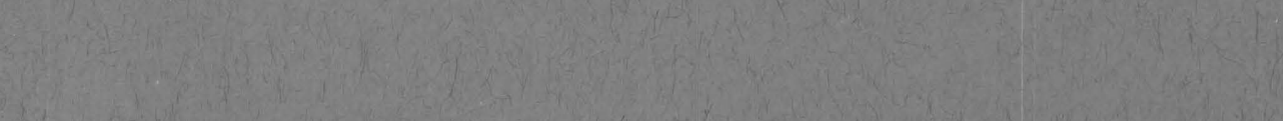

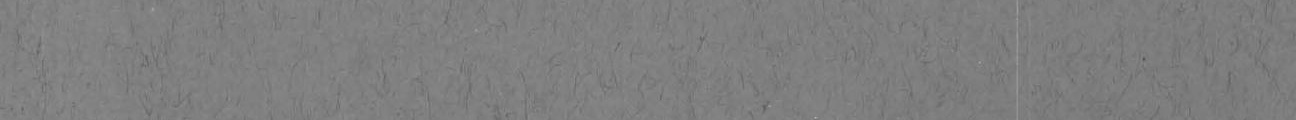

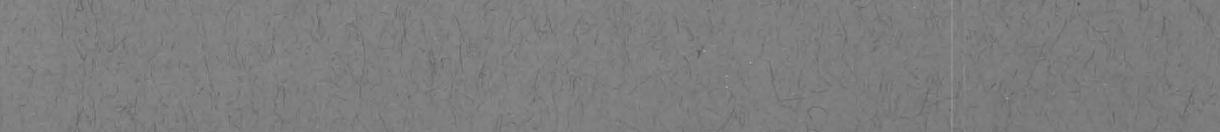

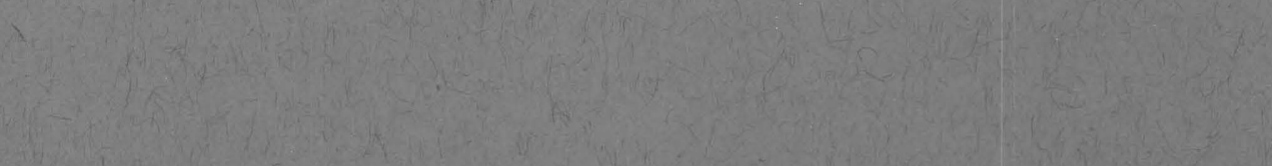

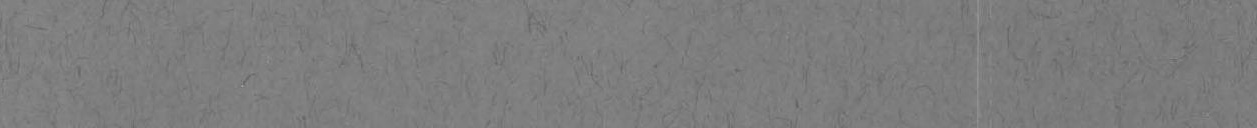

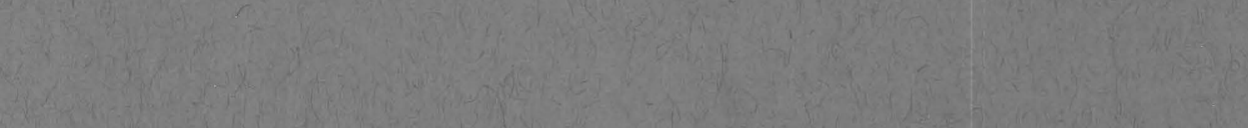

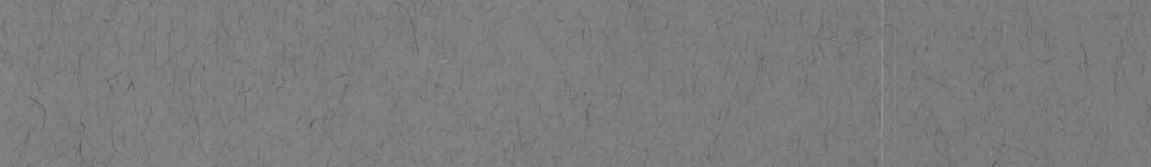

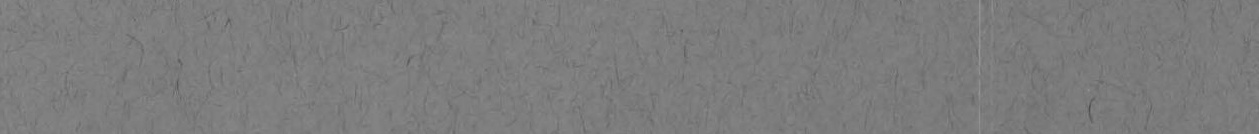

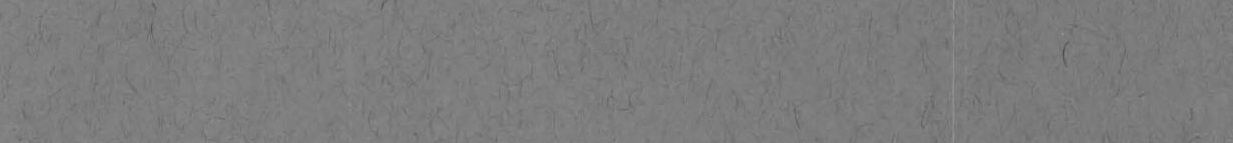

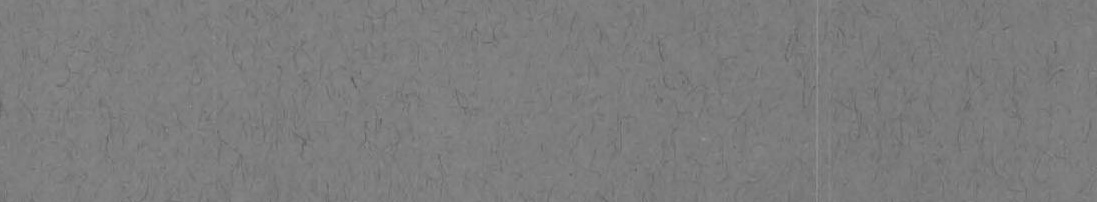
(n) (2)

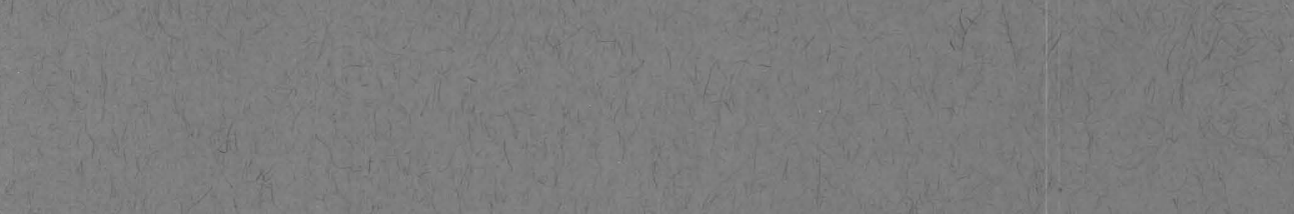

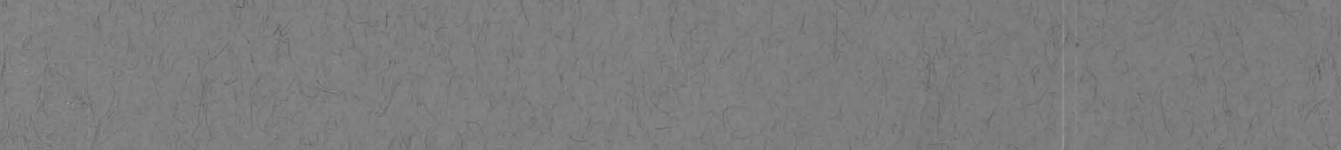

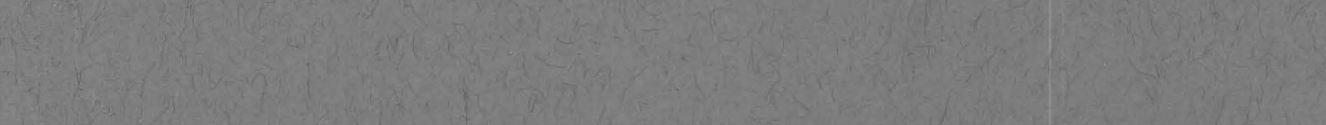

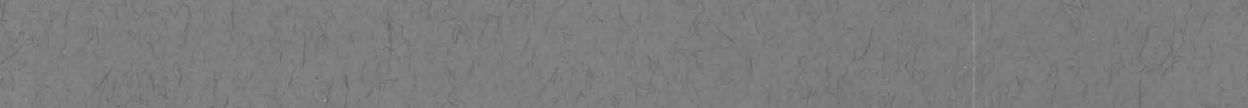

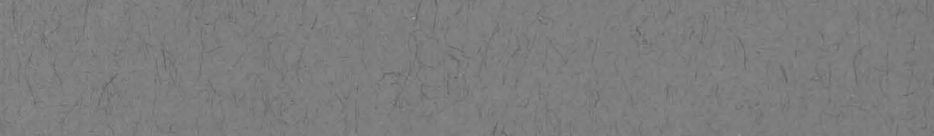

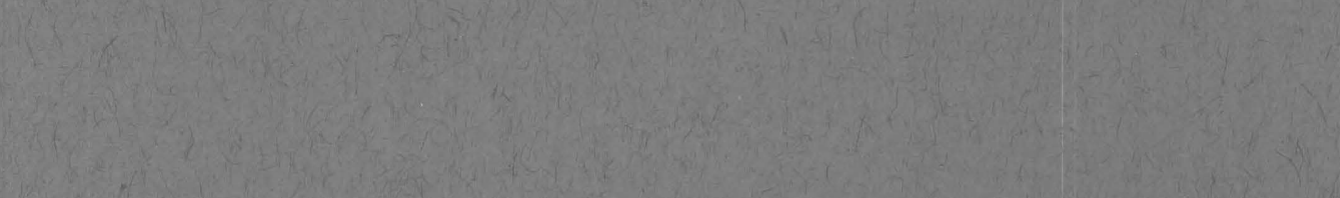
A.

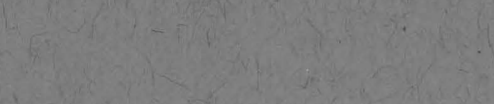
(a) $)^{3}$

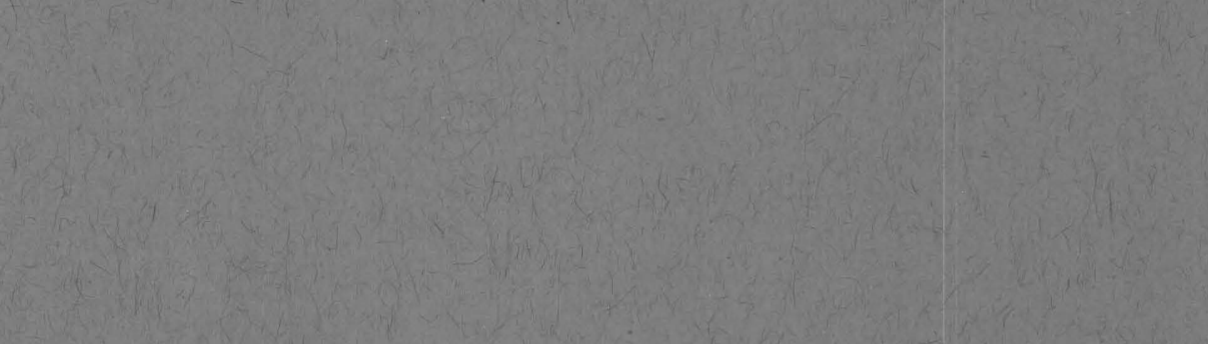

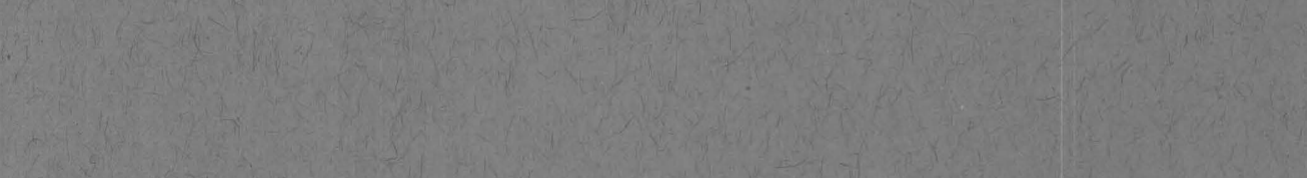




\section{General Geology of}

\section{the Hahns Peak and}

Farwell Mountain Quadrangles,

\section{Routt County, Colorado}

By KENNETH SEGERSTROM and E. J. YOUNG

With a discussion of UPPER TRIASSIC AND

PRE-MORRISON JURASSIC ROCKS

By G. N. PIPIRINGOS

G E O L O G I C A L S U R V E Y

B U L L E T I N 1349

A geologic study of the east end

of the Elkhead Mountains and

a part of the Park Range

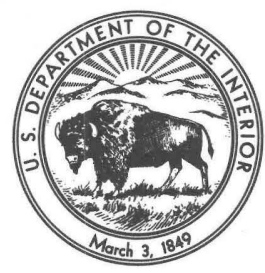




\section{UNITED STATES DEPARTMENT OF THE INTERIOR}

ROGERS C. B. MORTON, Secretary

\section{GEOLOGICAL SURVEY}

V. E. McKelvey, Director

Library of Congress catalog-card No. 72-600096

For sale by the Superintendent of Documents, U.S. Government Printing Office Washington, D.C. 20402 Stock Number 2401-2172 


\section{CONTENTS}

Abstract Page

1

Introduction

Location ................................................................................................... 2

Previous and other work.......................................................................

Fieldwork and acknowledgments................................................... 5

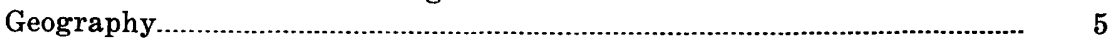

Topography ..................................................................................... 5

Climate and vegetation.................................................................. 5

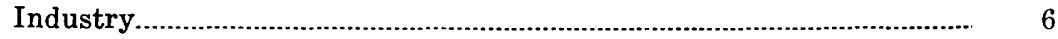

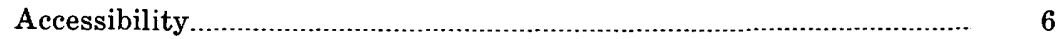

General geology

Precambrian rocks.................................................................................. 6

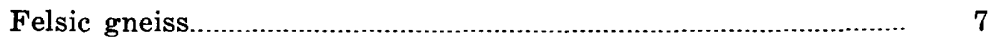

Felsic gneiss complex................................................................ 8

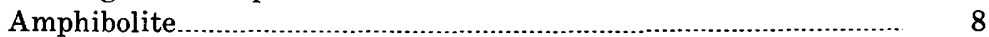

Amphibolite complex................................................................... $\quad 9$

Metaconglomerate................................................................ 9

Biotite gneiss ........................................................................ 12

Schist

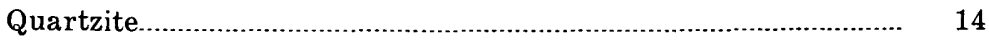

Augen gneiss .................................................................... 14

Quartz diorite gneiss........................................................... 15

Altered gneiss with dark-gray quartz and garnet-epidote skarn $\quad \mathbf{1 5}$

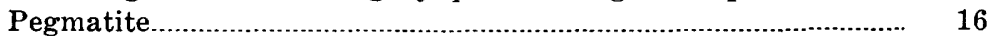

Age.................................................................................... 16

Permian and Lower Triassic rocks..................................................... 18

Goose Egg and Red Peak Formations......................................... 18

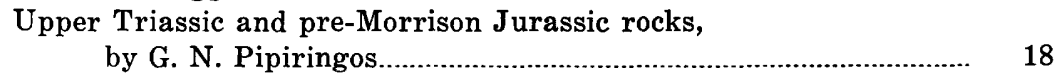

Jelm Formation........................................................................ 19

Popo Agie Formation................................................................... 23

Bell Springs Member of the Nugget Sandstone............................ 24

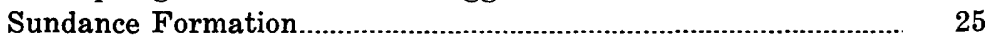

Canyon Springs Sandstone Member........................................ 26

Pine Butte Member............................................................... 27

Redwater Shale Member............................................................ 28

Windy Hill Sandstone Member................................................ 28

Post-Sundance Jurassic rocks.......................................................... 29

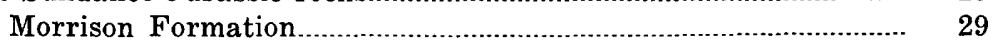

Cretaceous rocks.......................................................................... 29

Dakota Sandstone................................................................... $\quad 29$

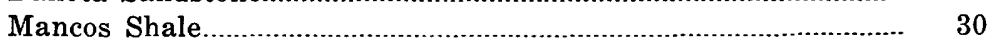

Miocene and Pliocene (?) rocks....................................................... 31

Browns Park Formation............................................................... 31 
General geology-Continued

Pliocene rocks.

Epiclastic volcanic rocks............................................................... 33

Intrusive and flow rocks................................................................ 34

Age of extrusive and intrusive rocks......................................... 40

Contact metamorphic rocks......................................................... 41

Quaternary deposits.................................................................... 42

Pre-Bull Lake till

Bull Lake (?) Till......................................................................... 43

Pinedale (?) Till...................................................................... 43

Terrace gravels........................................................................ 44

Landslide deposits................................................................ 44

Colluvium ................................................................................ 45

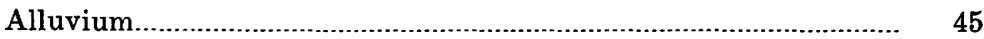

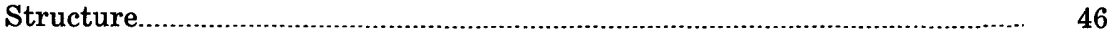

Structural features in Precambrian rocks.......................................... 46

Early Tertiary folds and overthrusts................................................... 46

Miocene and Pliocene intrusions, faults, and tilting of beds................ 48

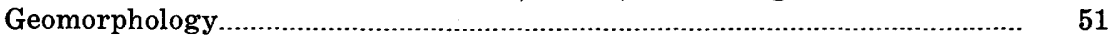

Pre-Browns Park erosion surface....................................................... 51

Development of the modern landscape ............................................. $\quad 52$

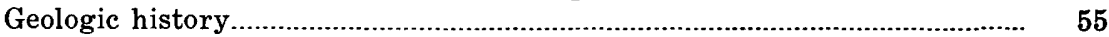

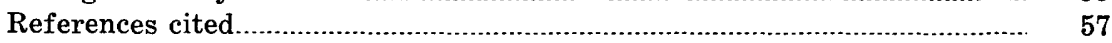

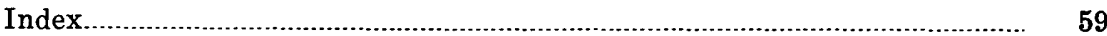

\section{ILLUSTRATIONS}

Plate 1. Geologic map and sections of the Hahns Peak and Farwell Mountain quadrangles, Routt County, Colo In pocket

Figure 1. Index map of Colorado and Wyoming, showing report area and line of stratigraphic sections listed in table 4

2. Map showing areas studied by Wyoming University graduate students, 1955-60.

3. Restored section showing correlation and dominant lithologies of the Jelm Formation and overlying rocks to the top of the Pine Butte Member of the Sundance Formation in southern Wyoming and north-central Colorado......

4. Restored section showing correlation and dominant lithologies of the Redwater Shale and Windy Hill Sandstone Members of the Sundance Formation in southern Wyoming and north-central Colorado.

5. Contour diagram of poles to 102 joints in Precambrian rocks of the Hahns Peak and Farwell Mountain quadrangles 


\section{TABLES}

TABLE 1. Chemical, modal, and spectrographic analyses of metamorphic rocks in Hahns Peak and Farwell Mountain quadrangles

2. Rubidium-strontium data from felsic gneiss and augen

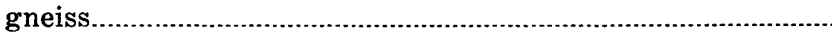

3. Potassium-argon ages of minerals separated from Precambrian rocks.

4. Names and locations of stratigraphic sections shown in figures 3 and 4

Page

Chemical and spectrographic analyses of Tertiary igneous rocks in Hahns Peak and Farwell Mountain quadrangles....

6. Potassium-argon ages of sanidine and biotite separated from upper Tertiary igneous rocks.

7. Chemical analysis of a contact metamorphic rock in the Hahns Peak quadrangle. 



\title{
GENERAL GEOLOGY OF THE HAHNS PEAK AND FARWELL MOUNTAIN QUADRANGLES, ROUTT COUNTY, COLORADO
}

\author{
By Kenneth Segerstrom and E. J. Young
}

\begin{abstract}
The Hahns Peak and Farwell Mountain quadrangles are on the west flank of the Park Range, east of the Elkhead Mountains, in northwestern Colorado. The quadrangles are about 125 airline miles northwest of Denver and about 8 miles south of the Wyoming-Colorado border.

The area is underlain by Precambrian crystalline rocks; Permian, Mesozoic, and upper Tertiary sedimentary rocks; upper Tertiary intrusive and extrusive igneous rocks; and Quaternary surficial deposits. The oldest rocks are Precambrian paragneiss, schist, and amphibolite, which contain a few intercalations of quartzite and metaconglomerate; marble is very sparse. The age of all Precambrian rocks is believed to be about 1,700 million years.

Permian and Mesozoic sedimentary rocks, which have a total thickness of about 2,000 feet, crop out in two north-trending basins, or synclines, in the mainly Precambrian terrane of the Farwell Mountain quadrangle, in much of the north half of the Hahns Peak quadrangle, and in small erosional windows in the south half of the Hahns Peak quadrangle. From oldest to youngest, these rocks are red siltstone and sandstone of the Goose Egg and Red Peak Formations of Permian and Early Triassic age; limestone, claystone, siltstone, and sandstone of the Jelm and Popo Agie Formations of Late Triassic age; the Bell Springs Member of the Nugget Sandstone of Triassic(?) age; marine siltstone and shale of the Sundance Formation of Late Jurassic age; fluviatile and lacustrine beds of the Morrison Formation of Late Jurassic age; conglomerate and sandstone of the Dakota Sandstone of Early Cretaceous age; and the marine Mancos Shale of Early and Late Cretaceous age. No large angular unconformities in the Mesozoic were found in the two quadrangles, an area about midway along a 150-mile north-south stratigraphic section studied by Pipiringos and described in this report.

Sandstone, conglomerate, and a few ash beds of the Browns Park Formation of Miocene and Pliocene (?) age crop out extensively in the Hahns Peak quadrangle and near the northeast corner of the Farwell Mountain quadrangle. The conglomerate, which is well cemented and made up largely of Precambrian clasts, occurs at the base of the Browns Park in lenses as much as 300 feet thick. The sandstone is red to yellow, is mostly uncemented except in the clayey beds near the base, and forms discontinuous cover, as much as 800 feet thick, over Mesozoic rocks. Interbedded ash beds are fine grained and white. They are of rhyodacitic composition and contain biotite and are not more than 2 feet thick.
\end{abstract}

Tertiary igneous rocks intruded the Browns Park Formation, and lava flows and pyroclastics cap the Browns Park in the Hahns Peak quadrangle. 
In the Farwell Mountain quadrangle, igneous rocks consist of only a few narrow dikes. Almost all the intrusions are porphyries of intermediate composition, characterized by large sanidine phenocrysts in a fine-grained holocrystalline groundmass composed largely of oligoclase, quartz, and biotite. The age of these intrusions ranges from 9 to 11.5 million years-in the Pliocene, as currently accepted by the U.S. Geological Survey. The epiclastic volcanic rocks on a hill 1 mile west-northwest of Hahns Peak probably represent the extrusive equivalent of a porphyry intrusion at Hahns Peak. Basaltic flows and dikes crop out in the southwest quarter and at the north edge of the Hahns Peak quadrangle.

Surficial deposits of Quaternary age cover about 35 percent of the area. Till of three glaciations is distributed widely in the Farwell Mountain quadrangle; the two younger tills may be correlative with the Bull Lake(?) and Pinedale(?) Glaciations of Wyoming. Landslide deposits cover much of the south slope of Farwell Mountain, where the relief is exceptionally great; they also cover hillslopes in the southern part of the Hahns Peak quadrangle, where Mancos Shale is capped by Browns Park conglomerate. The colluvial deposits which extend radially from Hahns Peak are gold bearing and have been placer mined.

Structurally, the mapped area lies on the west flank of the north-trending Park Range anticlinal uplift and extends westward into the Elkhead Mountains laccolithic and volcanic highland. The gross trend of foliation in the Precambrian core of the uplift is northeast. Folds in the Precambrian rocks strike north to northwest, parallel to the axial crest of the Park Range. Outliers of Mesozoic rocks are overridden by basement rocks along the east sides of the sags. Tertiary and older rocks are locally domed by shallow intrusions, and they are displaced along several west-trending faults that approximately parallel the trend of the Elkhead Mountains. Lateral shifts along one or more of these faults have caused mismatching of basement folds and overthrusts. Vertical displacements along the same west-trending faults have imposed a horst-and-graben structure on the already complexly deformed rocks. The major tectonic events that produced the foliation, folds, and west-trending faults occurred during Precambrian, early Tertiary, and Pliocene times, respectively.

Major steps in development of the Hahns Peak-Farwell Mountain landscape were (1) formation of a pre-Browns Park erosion surface, which had less relief than that of today; (2) burial of that surface by the Browns Park Formation; (3) intrusion of porphyry and, very locally in the western part, capping by lava; (4) superposition of drainage, stripping of Browns Park Formation, and exposure of porphyry intrusions; (5) glaciation only in eastern part of area and dissection of exhumed parts of the pre-Browns Park surface.

\section{INTRODUCTION \\ LOCATION}

The Hahns Peak and Farwell Mountain quadrangles constitute an area of about 112 square miles in the northeastern part of Routt County, Colo. (fig. 1), between lats $40^{\circ} 45^{\prime}$ and $40^{\circ} 52^{\prime} 30^{\prime \prime} \mathrm{N}$. and longs $106^{\circ} 45^{\prime}$ and $107^{\circ} \mathrm{W}$. The area is about 125 miles northwest of Denver, and 20 miles north of Steamboat Springs, the county seat. Hahns Peak is an historic landmark of northwestern Colorado. 


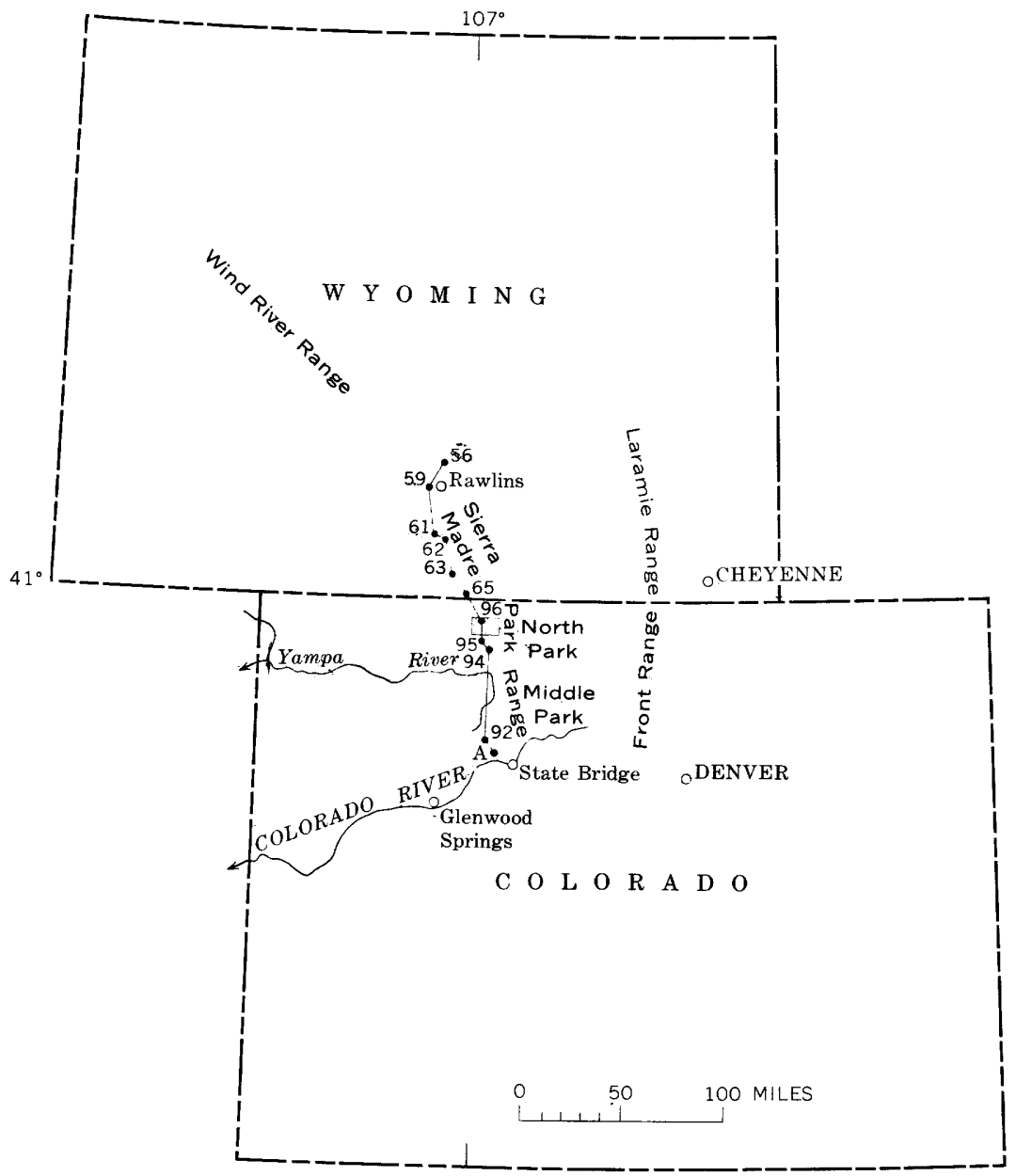

FIgURE 1. - Index map of Colorado and Wyoming, showing report area and line of stratigraphic sections, designated by number or letter. Sections are listed in table 4.

\section{PREVIOUS AND OTHER WORK}

The Hahns Peak mining district, in the north-central part of the Hahns Peak quadrangle, was mapped and studied geologically several times before current investigations were undertaken. The first mention of the area in geologic literature was only a few years after Joseph Hahn discovered placer gold there (Hague and Emmons, 1877, p. 173-174). Subsequently, two reconnaissance studies of Hahns Peak and vicinity were made by Gale (1906) and by George and Crawford (1909). Glacial features of the Park Range, including those of the Farwell Mountain quadrangle, were described by Atwood (1937). Virtually the entire area of the two quadrangles 
was mapped by graduate students of the University of Wyoming under a program designed to meet requirements for Master of Science degrees (Barnwell, 1955; Hunter, 1955; Murphy, 1958; McConnell, 1960) ; location of the area of this work is shown in figure 2. The Browns Park Formation and its relation to the late Tertiary geologic history of the Elkhead Mountains region were studied by Buffler (1967). From 1963 to date (1969), minerals exploration of the Hahns Peak district and other mineralized areas has been intensively carried out for private interests under the direction of W. A. Bowes, utilizing geochemistry, geophysics (mainly the methods used in determining electrical resistivity and induced polarization), and trenching and drilling.

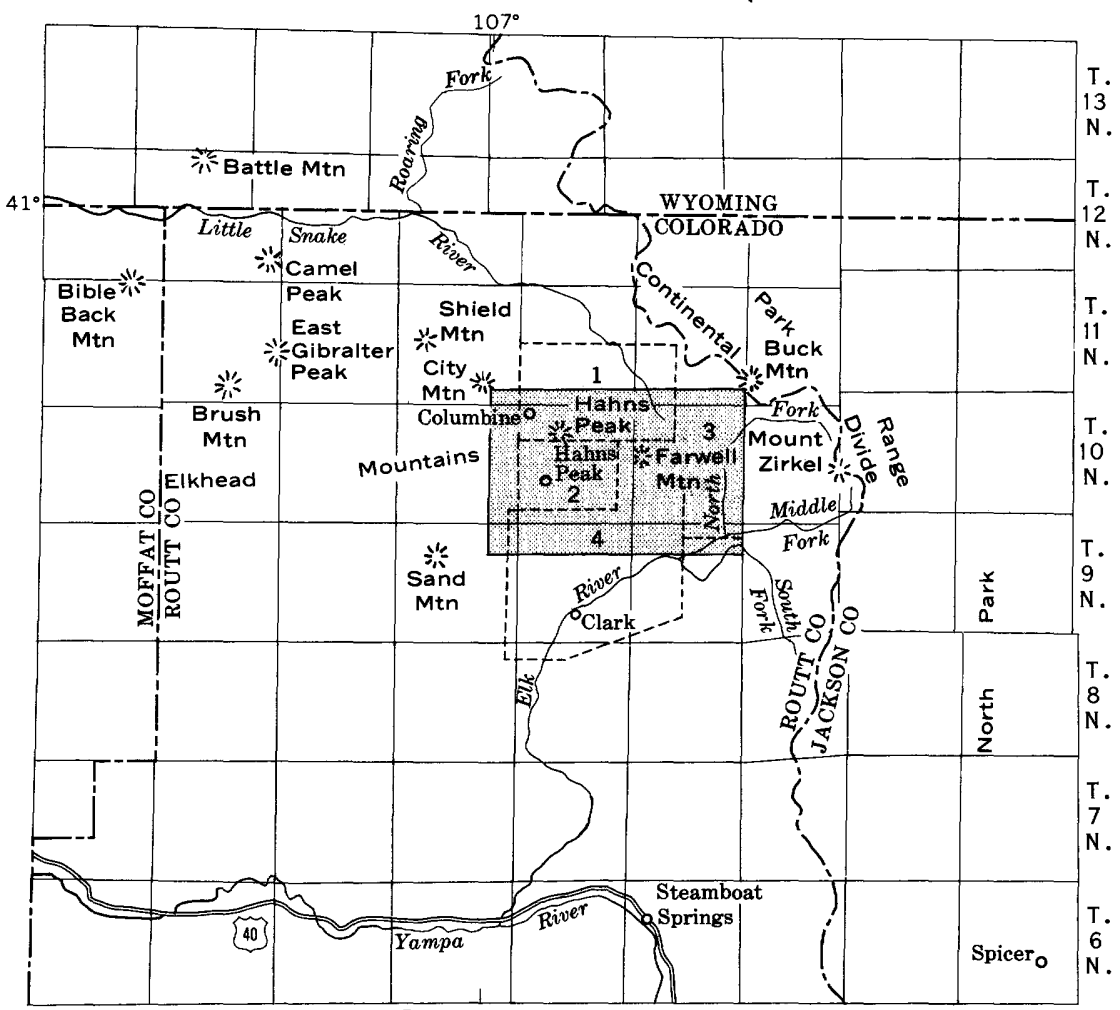

R. 89 W. R. 88 W. R. 87 W. R. 86 W. R. 85 W. R. 84 W. R. 83 W.R. 82 W. R. 81 W.

10 20 MILES

FIgURE 2. - Index map of part of northwestern Colorado, showing location of the report area (shaded area) and other pertinent localities mentioned in the report. Areas mapped by University of Wyoming graduate students in 1955-60 are outlined by dashed lines and numbered as follows: 1, Hunter, 1955; 2, Barnwell, 1955; 3, Murphy, 1958; 4, McConnell, 1960. 


\section{FIELDWORK AND ACKNOWLEDGMENTS}

The field investigations were made by Segerstrom during the summers of 1966-68, and by Young during the summers of 1967-68. Stephen H. Kirby capably assisted in mapping the Hahns Peak quadrangle in 1967. Field mapping of Hahns Peak and vicinity was done on planetable sheets, at 1 inch $=400$ feet and of the rest of the area on enlargements $\times 2$ of the $1: 24,000$ published quadrangle maps. Black-and-white aerial photographs of both quadrangles, taken for the U.S. Forest Service in 1955, and color aerial photographs of the Hahns Peak quadrangle, taken by Western State Aviation Co. in 1968, aided in interpretation of features observed on the ground.

The descriptions and correlations of Upper Triassic and preMorrison Jurassic rocks by G. N. Pipiringos are based on his regional studies of these rocks from central Wyoming to central Colorado during 1958-69. These rocks are relatively poorly exposed in the Hahns Peak and Farwell Mountain quadrangles, and their identification and correlations with other areas would have been inadequate without Pipiringos' specialized knowledge.

\section{GEOGRAPHY}

\section{TOPOGRAPHY}

Hahns Peak is a fairly isolated mountain which rises about 2,000 feet above the surrounding country. To the west are rugged peaks of the west-trending Elkhead Mountains, and to the east are high hills and broad slopes that form the west flank of the north-trending Park Range. The highest points, about 10,840 feet above sea level, are the summits of Farwell Mountain and Hahns Peak. The lowest point, about 7,600 feet, is on the Elk River at the south edge of the area. Most of the drainage is southward into the Elk River; about 10 percent is northward into tributaries of the Little Snake River.

\section{CLIMATE AND VEGETATION}

Northern Routt County has a cool moist climate. Precipitation records kept at Columbine station, altitude 8,700 feet, show an annual average of 39.7 inches for May 1949 to June 1955 (U.S. Weather Bur., 1960, p. 19) ; this total includes the water equivalent of the snowfall. The average annual snowfall at Columbine station was 184.5 inches for 1910-40 inclusive (J. W. Berry, State Climatologist, written commun., 1969) ; the water equivalent is about 10 percent of measured snowfall. No temperature records are available for the area, but records kept at the Spicer station, altitude 8,250 feet, about 30 miles southeast of the area, show a mean January temperature of about $16^{\circ} \mathrm{F}$ and a mean July temperature of about $59^{\circ} \mathrm{F}$. 
Most of the area in its natural state is heavily forested, because it is well watered and is well below the upper limit of tree growth, which, regionally, is between 11,000 and 11,500 feet above sea level. Much of the north half of the Farwell Mountain quadrangle has only scattered groves of trees interspersed with grassy areas, for it has never completely recovered from the disastrous forest fires of the 1880 's. Forest trees of the area are mainly aspen, lodgepole pine, and Engelmann spruce. An area of about 7 square miles, extending south from Hahns Peak village nearly to Willow Creek Canyon, is natural "parkland"-where trees are few, and sagebrush and grasses are the principal vegetal cover.

\section{INDUSTRY}

Tourism and stockraising are the principal industries of the area. Hahns Peak Lake, Steamboat Lake, and Lester Creek Reservoir are artificial bodies of water, created especially for fishing, boating, and water skiing. The grouse-, deer-, and elk-hunting seasons in the fall attract large numbers of visitors. Many thousands of sheep are brought in from lower pastures on the west for summer grazing on National Forest and privately owned land.

A small amount of hay is cut, but, in general, the climate is too cold for the growing of crops. At the time the present report was written (1969), there were no logging operations in the area; also, there was considerable activity in metals exploration at Hahns Peak, but no mining was being done.

\section{ACCESSIBILITY}

No U.S. or State Highways cross the area, nor are there any hard-surfaced roads. A county road, connecting U.S. Highway 40, on the south, with the Wyoming State Highway system, on the north, traverses the western part of the area. A dead-end road branches off the county road and traverses the Elk River valley, in the extreme southeastern part of the area. Both of these roads are gravel-surfaced all-weather roads. Other roads and jeep trails in the area are passable only from June through October. Most of the Farwell Mountain quadrangle is accessible only by use of fourwheel-drive vehicles.

\section{GENERAL GEOLOGY}

The Hahns Peak and Farwell Mountain quadrangles are underlain by a crystalline basement complex of Precambrian age, sedimentary rocks of Mesozoic and Cenozoic ages, and igneous rocks (mostly intrusive) of Tertiary age. Distribution of the rocks is shown on plate 1 .

\section{PRECAMBRIAN ROCKS}

The Precambrian rocks in the two quadrangles are divided into 12 mapped units. Each unit is designated by its dominant lithology, 
even though some of the lithologic types overlap. Relative age among most of the units is uncertain; however, an effort is made in this report to indicate (1) which rocks are unmistakably metasedimentary, (2) which rocks may have been formed by the addition of magmatic material, and (3) which rocks were formed at least partly by late (hydrothermal) addition of material. These three groups are discussed in order of probable age, from oldest to youngest. Structural relationships show that the gray schist and gray quartzite are clearly younger than the other metasedimentary units.

The gneiss and schist units tend to be very fine grained. Common grain-size range is from 0.1 to $0.3 \mathrm{~mm}$ (millimeters). Relict sedimentary features, such as graded bedding, are not common, and crossbedding and heavy-mineral streaks were seen in the quartzite and schist units. Most of the Precambrian rocks in the two quadrangles are metasedimentary or metavolcanic. The rock units represent regional metamorphism to the almandine-amphibolite facies. Stratigraphic thicknesses cannot be measured, because the extent to which the original beds are repeated by isoclinal folding cannot be determined.

FELSIC GNEISS

Felsic gneiss is the dominant metamorphic rock in the northeast quarter of the Hahns Peak quadrangle and the adjacent northwest quarter of the Farwell Mountain quadrangle. Broad areas near the center of the Farwell Mountain quadrangle, as well as some narrower zones elsewhere in the same quadrangle, are also mapped as felsic gneiss. This gneiss is characterized by its light color-generally pale pink to light red-its low mafic-mineral content, and the almost ubiquitous presence of microcline. The rock is both fine and coarse grained.

The finer grained felsic gneiss is granular with equant grains. Grain size is generally very fine, the average being about $0.2 \mathrm{~mm}$, but at some places maximum size is $1 \mathrm{~mm}$. A small mica content reveals foliation. Sparse heavy-mineral streaks were found, both in hand specimen and in thin section. Very fine grained rock, which should probably be named microfelsic paragneiss, underlies most of sec. 12 , T. 10 N., R. 85 W., where its outcrops are poorly exposed.

Coarser varieties of felsic gneiss are variable in grain size. Their individual grains interlock more than do the finer grained varieties, and the size of some of their quartz and feldspar grains is as much as several millimeters.

Despite the homogeneous appearance of outcrops of this coarser variety, foliation is almost invariably present. In and near Hinman Canyon and Hole-in-Wall Canyon, medium- to coarse-grained felsic gneiss forms steep cliffs, and where the gneiss has been subjected to glaciation, it tends to form bold, rounded knobs. 
Principal minerals in the felsic gneiss are quartz, microcline, and plagioclase (albite or oligoclase). $\mathrm{KAlSi}_{3} \mathrm{O}_{8}$ content of the microcline is 93 and 94 percent, as measured for two specimens by means of the $\overline{2} 01$ X-ray method of Tuttle and Bowen (1958). Disseminated rounded quartz blebs and wormlike intergrowths of quartz in the microcline are common. Some of the microcline is microperthitic. Biotite or muscovite, or both, are present in small amounts. Hornblende, sphene, and garnet are uncommon. Common accessory minerals are black opaque minerals, zircon, and apatite. Colorless fluorite was found in only two specimens (locs. 227 and 95, table 1). Locally, disseminated hematite clots, $1-3 \mathrm{~mm}$ long, occur in the gneiss. In finer grained varieties the accessory minerals commonly occur as streaks that are relict bedding planes. Individual grains are small, 4-10 microns in diameter, and rounded. Overgrowths on zircons were noted in several specimens.

Chemical, modal, and spectrographic analyses, as well as the densities of two samples, of felsic gneiss are given in table 1 . The modal analyses are based on at least 500-point counts. According to VanderPlas and Tobi (1965), a constituent that measures 28 percent by volume will equal $24-32$ percent, with 95 percent confidence, when determined by a 500 -point count.

\section{FELSIC GNEISS COMPLEX}

Areas of felsic gneiss complex are those which are predominantly composed of felsic gneiss, but which may also contain lenses of mafic gneiss, schist, or amphibolite. As a consequence of a generally more mafic bulk composition than that of the commonly pink to light-red felsic gneiss, much of the rock in the unit mapped as felsic gneiss complex is gray.

Average grain size ranges from about 0.1 to $1 \mathrm{~mm}$. Textures are granular in the finer grained varieties. The coarser grained varieties vary more in grain size.

Quartz, plagioclase (predominantly oligoclase), and microcline are the principal minerals in the more felsic varieties. Biotite or hornblende, or, commonly, both, are the mafic minerals. Muscovite is present in the more felsic varieties. Black opaque minerals, sphene, and apatite are the common accessory minerals, although zircon, epidote, chlorite, and garnet occur locally.

Chemical, modal, and spectrographic analyses and densities of two samples from the felsic gneiss complex are given in table 1.

\section{AMPHIBOLITE}

Dark-gray amphibolite is the predominant rock on the summits of Farwell Mountain and Dome Peak and on the lower part of the northwest flank of Little Farwell Mountain. It is generally conformable with the adjacent felsic gneiss. Hornblende content of the am- 
phibolite varies from place to place from about 20 percent to almost 100 percent, but most rock of the unit contains $30-60$ percent. Grain sizes of the amphibolite vary more than those of the biotite gneiss of schist units. Although fine sizes $(0.2-0.4 \mathrm{~mm})$ are prevalent, the more massive varieties of amphibolite contain some grains as much as half a centimeter long. A variety of coarse-grained amphibolite, sometimes called "leopard rock," contains rounded clots of hornblende surrounded by plagioclase.

Generally, the amphibolite unit in the study area is less susceptible to weathering than are the other rock types (except quartzite), and it therefore tends to form bold knobs and monadnocklike outcrops. The largest of these bodies is at the summit of Farwell Mountain, where the amphibole is an actinolite-tremolite variety. The actinolite-tremolite is secondary; what appear in hand specimen to be grains $1 \mathrm{~mm}$ or more across are shown in thin section to be felty interlocking laths and aggregates that have replaced previous grains (pyroxenes?). The texture and composition of this amphibole account for the hardness and durability of the rock. The relatively larger "normal" hornblende crystals found along the fracture and joint surfaces in the rock were probably formed later.

Essential minerals of the amphibolite are amphibole (commonly hornblende) and plagioclase (commonly, andesine; less commonly, labradorite). Recrystallization of the plagioclase $\left(\mathrm{An}_{45^{-50}}\right)$ is well shown in sample 5 (field loc. 52) in which euhedral crystals of plagioclase seem to be neatly stacked together. In sample 5 (table 1) and in other samples, the plagioclase appears to be remarkably fresh. Quartz is present in some of the amphibolite, but it is not abundant. Chlorite and biotite commonly occur in small amounts. Garnet and epidote are common locally, and calcite is a common trace mineral. Microcline is rarely present. Black opaque minerals, sphene, and apatite are the usual accessory minerals. In the more massive amphibolite, sphene, which constitutes as much as 3 percent of the rock, commonly occurs as clusters of minute yellow grains.

Chemical, modal, and spectrographic analyses and densities of two specimens of amphibolite are given in table 1.

\section{AMPHIBOLITE COMPLEX}

Areas mapped as amphibolite complex in the Farwell Mountain quadrangle are those which are predominantly an amphibolite, petrographically like that described under the section "Amphibolite," but which include numerous interbeds and lenses of biotite gneiss, felsic gneiss, and schist.

\section{METACONGLOMERATE}

Light- to dark-gray metaconglomerate crops out in two small areas north of the summit of Farwell Mountain. The most striking 
TABLE 1. - Chemical, modal, and spectrographic analyses of metamorphic rocks in Hahns Peak and Farwell Mountain quadrangles [Tr., trace; leaders (....), not determined. Analysts for the rapid-rock-chemical analyses: P. L. D. Elmore, Gillison Chloe, James Kelsey, S. D. Botts, H. Smith, Lowell Artis, and John Glenn. Modes determined by E. J. Young. The following elements were looked for by semiquantitative spectrographic analysis but were not detected (detection limit in parentheses): Ag (0.1), As (100), Au (10), B (30), Bi (3), Cd (100), Analysts for the semiquantitative spectrographic analyses : For samples $1,7,8$, and 9, J. L. Harris ; for all other samples, W. B. Crandell]

\begin{tabular}{|c|c|c|c|c|c|c|c|c|c|c|c|c|c|}
\hline \multirow[b]{2}{*}{$\begin{array}{l}\text { Sample No.......... } \\
\text { Lab. No... No... } \\
\text { Field loc. }\end{array}$} & \multicolumn{2}{|c|}{ Felsic gneiss } & \multicolumn{2}{|c|}{$\begin{array}{c}\text { Felsic gneiss } \\
\text { complex }\end{array}$} & \multicolumn{2}{|c|}{ Amphibolite } & \multicolumn{2}{|c|}{ Biotite gneiss } & \multicolumn{2}{|c|}{ Schist } & \multirow{2}{*}{$\begin{array}{c}\begin{array}{c}\text { Augen } \\
\text { gneiss }\end{array} \\
11 \\
79 \mathrm{~A} \\
\end{array}$} & \multicolumn{2}{|c|}{$\begin{array}{c}\text { Quartz diorite } \\
\text { gneiss }\end{array}$} \\
\hline & $\begin{array}{c}1 \\
\text { W } 170253 \\
227 \\
\end{array}$ & $\begin{array}{c}2 \\
\mathrm{~W} 171433 \\
95 \\
\end{array}$ & $\begin{array}{c}3 \\
\mathrm{~W} 171430 \\
21 \\
\end{array}$ & $\begin{array}{c}4 \\
\mathrm{~W} 171436 \\
129 \\
\end{array}$ & $\begin{array}{c}5 \\
\mathrm{~W} 171432 \\
52 \\
\end{array}$ & $\begin{array}{c}6 \\
\mathrm{~W} 171435 \\
124 \\
\end{array}$ & $\begin{array}{c}7 \\
\mathrm{~W} 170257 \\
3 \\
\end{array}$ & $\begin{array}{c}8 \\
\mathrm{~W} 170258 \\
78 \\
\end{array}$ & $\begin{array}{c}9 \\
\text { W } 170256 \\
110 \\
\end{array}$ & $\begin{array}{c}10 \\
\mathrm{~W} 171426 \\
1 \\
\end{array}$ & & $\begin{array}{c}12 \\
\mathrm{~W} 171434 \\
96 \\
\end{array}$ & $\begin{array}{c}13 \\
\mathrm{~W} 171441 \\
228 \\
\end{array}$ \\
\hline \multicolumn{14}{|c|}{ Rapid-rock-chemical analyses for major constituents (weight percent) } \\
\hline $\begin{array}{l}\mathrm{SiO}_{2} \\
\mathrm{Al}_{2} \mathrm{O}_{3} \\
\mathrm{Fe}_{2} \mathrm{O}_{3} \\
\mathrm{FeO} \\
\mathrm{MgO}\end{array}$ & $\begin{array}{c}75.7 \\
12.7 \\
1.2 \\
.52 \\
.17\end{array}$ & $\begin{array}{c}76.6 \\
12.6 \\
1.3 \\
.16 \\
.08\end{array}$ & $\begin{array}{c}73.3 \\
13.6 \\
.72 \\
1.8 \\
.60\end{array}$ & $\begin{array}{r}74.4 \\
11.6 \\
1.6 \\
2.9 \\
1.3\end{array}$ & $\begin{array}{r}49.2 \\
18.3 \\
2.0 \\
7.6 \\
6.1\end{array}$ & $\begin{array}{r}50.7 \\
14.8 \\
3.1 \\
8.7 \\
6.5\end{array}$ & $\begin{array}{r}41.0 \\
21.7 \\
4.7 \\
10.4 \\
3.5\end{array}$ & $\begin{array}{r}62.4 \\
16.3 \\
1.0 \\
6.0 \\
2.5\end{array}$ & $\begin{array}{l}71.3 \\
14.3 \\
.32 \\
3.8 \\
2.1\end{array}$ & $\begin{array}{r}72.2 \\
13.9 \\
1.2 \\
2.5 \\
1.5\end{array}$ & (….. & $\begin{array}{l}70.1 \\
16.2 \\
.93 \\
1.7 \\
1.1\end{array}$ & $\begin{aligned} 68.1 \\
16.9 \\
1.2 \\
1.5 \\
1.0\end{aligned}$ \\
\hline $\begin{array}{l}\mathrm{CaO} \\
\mathrm{Na} \mathrm{O}_{2} \mathrm{O} \\
\mathrm{K}_{3} \mathrm{O} \\
\mathrm{H}_{2} \mathrm{O}- \\
\mathrm{H}_{2} \mathrm{O}+\end{array}$ & $\begin{array}{l}.65 \\
3.0 \\
5.0 \\
.08 \\
.57\end{array}$ & $\begin{array}{l}.52 \\
3.2 \\
4.3 \\
.22 \\
.30\end{array}$ & $\begin{array}{l}1.9 \\
2.1 \\
5.0 \\
.22 \\
.46\end{array}$ & $\begin{array}{l}1.7 \\
2.9 \\
2.2 \\
.26 \\
.72\end{array}$ & $\begin{array}{c}10.4 \\
2.6 \\
.80 \\
.22 \\
.78\end{array}$ & $\begin{array}{c}10.7 \\
2.4 \\
.40 \\
.20 \\
.65\end{array}$ & $\begin{array}{l}4.4 \\
1.6 \\
6.1 \\
.35 \\
2.4\end{array}$ & $\begin{array}{l}2.8 \\
3.2 \\
2.8 \\
.13 \\
1.5\end{array}$ & $\begin{array}{l}.69 \\
1.9 \\
3.0 \\
.08 \\
1.2\end{array}$ & $\begin{array}{l}1.4 \\
1.5 \\
3.8 \\
.22 \\
1.0\end{array}$ & 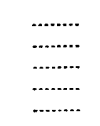 & $\begin{array}{l}3.4 \\
4.1 \\
1.3 \\
.18 \\
.63\end{array}$ & $\begin{array}{l}3.8 \\
4.0 \\
.83 \\
.24 \\
1.1\end{array}$ \\
\hline $\begin{array}{l}\mathrm{TiO}_{2} \\
\mathrm{P}_{2} \mathrm{O}_{5} \\
\mathrm{MnO} \\
\mathrm{CO}_{2}\end{array}$ & $\begin{array}{r}.18 \\
.03 \\
.02 \\
<.05 \\
\end{array}$ & $\begin{array}{l}.07 \\
.02 \\
.00 \\
.18 \\
\end{array}$ & $\begin{array}{r}.25 \\
.05 \\
.04 \\
<.05 \\
\end{array}$ & $\begin{array}{r}.32 \\
.06 \\
.08 \\
<.05 \\
\end{array}$ & $\begin{array}{l}.89 \\
.13 \\
.17 \\
.08 \\
\end{array}$ & $\begin{array}{l}1.3 \\
.25 \\
.21 \\
.05 \\
\end{array}$ & $\begin{array}{c}2.2 \\
.98 \\
.26 \\
.10 \\
\end{array}$ & $\begin{array}{l}.95 \\
.23 \\
.09 \\
.08 \\
\end{array}$ & $\begin{array}{r}.47 \\
.11 \\
.08 \\
<.05 \\
\end{array}$ & $\begin{array}{l}.30 \\
.06 \\
.07 \\
.05 \\
\end{array}$ & (n.... & $\begin{array}{r}.22 \\
.08 \\
.05 \\
<.05 \\
\end{array}$ & $\begin{array}{l}.26 \\
.08 \\
.05 \\
.15\end{array}$ \\
\hline Total & 100 & 100 & 100 & 100 & 99 & 100 & 100 & 100 & 99 & 100 & $\ldots \ldots . . .$. & 100 & 99 \\
\hline $\begin{array}{l}\overline{\text { Density }} \\
\text { Felsic-mafic }\end{array}$ & 2.654 & 2.641 & 2.668 & 2.717 & 2.971 & 3.026 & 2.898 & 2.821 & 2.777 & 2.716 & ........ & 2.708 & 2.697 \\
\hline index ${ }^{2} \ldots \ldots$ & 33.0 & 40.8 & 16.0 & 10.6 & 2.02 & 1.85 & 2.12 & 5.56 & 11.0 & 11.7 & .......... & 10.6 & 9.73 \\
\hline \multicolumn{14}{|c|}{ Modal analyses (point count of at least 500 points) of mineral constituents (volume percent) } \\
\hline 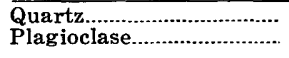 & $\begin{array}{l}35 \\
21_{\mathrm{An}_{13}}\end{array}$ & $\begin{array}{l}37 \\
25_{\mathrm{An}_{3}}\end{array}$ & $\begin{array}{l}41 \\
9_{\mathrm{An}_{28}}\end{array}$ & $\begin{array}{l}47 \\
30_{\mathrm{An}_{20}}\end{array}$ & $\begin{array}{c}0 \\
42_{\mathrm{An}_{48}}\end{array}$ & $\begin{array}{l}9 \\
3^{9 \mathbf{A n}_{45}}\end{array}$ & $\begin{array}{l}\mathbf{4 6}_{\mathrm{An}} \\
35\end{array}$ & $\begin{array}{l}26 \\
27_{\mathrm{An}_{32}}\end{array}$ & $\begin{array}{l}56 \\
8_{\mathrm{An}_{15}}\end{array}$ & $\begin{array}{l}49 \\
15_{\mathrm{An}_{20}}\end{array}$ & $\begin{array}{l}37 \\
18_{\mathrm{An}_{10}}\end{array}$ & $\begin{array}{l}41 \\
45_{\mathrm{An}}\end{array}$ & $\begin{array}{l}42 \\
52_{\mathrm{An}_{27}}\end{array}$ \\
\hline 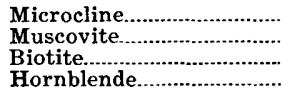 & $\begin{array}{l}41 \\
.4 \\
1.5 \\
0\end{array}$ & $\begin{array}{c}33 \\
4 \\
0\end{array}$ & $\begin{array}{r}37 \\
3 \\
8 \\
0\end{array}$ & $\begin{array}{r}8 \\
0 \\
11 \\
3\end{array}$ & $\begin{array}{r}0 \\
3 \\
0 \\
53\end{array}$ & $\begin{array}{r}0 \\
0 \\
0 \\
55\end{array}$ & $\begin{array}{r}0 \\
2 \\
48 \\
0\end{array}$ & $\underset{0}{0.4}$ & $\begin{array}{r}0 \\
13 \\
22 \\
0\end{array}$ & $\begin{array}{r}15 \\
10 \\
11 \\
0\end{array}$ & $\begin{array}{r}36 \\
3 \\
3 \\
0\end{array}$ & $\begin{array}{l}2.6 \\
0 \\
8 \\
.2\end{array}$ & $\begin{array}{l}0 \\
4^{.5}\end{array}$ \\
\hline 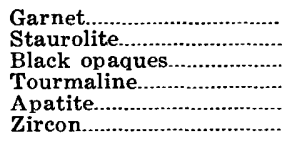 & $\begin{array}{l}0 \\
0 \\
0 \\
0_{\text {Tr. }}^{9} \\
\text { Tr. }\end{array}$ & $\begin{array}{l}0 \\
0 \\
.6 \\
0 \\
0 \\
0\end{array}$ & $\begin{array}{l}0 \\
0 \\
0 \\
0 \\
.9 \\
0\end{array}$ & $\begin{array}{l}.2 \\
0.2 \\
0 \\
0 \\
0\end{array}$ & $\begin{array}{l}0 \\
0 \\
0.1 \\
0.1 \\
0\end{array}$ & $\begin{array}{l}0 \\
0 \\
.4 \\
0.2 \\
0\end{array}$ & $\begin{array}{l}0 \\
0 \\
4 \\
0 \\
0 \\
0\end{array}$ & $\begin{array}{l}.6 \\
0.2 \\
0.7\end{array}$ & $\begin{array}{l}.4 \\
.2 \\
.4 \\
.2 \\
\text { Tr. } \\
\text { Tr. }\end{array}$ & $\begin{array}{l}0 \\
0 \\
0 \\
0 \\
0 \\
0\end{array}$ & $\begin{array}{l}0 \\
0 \\
1.3 \\
0 \\
0 \\
\quad .2\end{array}$ & $\begin{array}{l}0 \\
0 \\
0 \\
0 \\
0 \\
0\end{array}$ & ${ }_{0}^{0} \mathrm{Tr}$. \\
\hline
\end{tabular}




\begin{tabular}{|c|c|c|c|c|c|c|c|c|c|c|c|c|c|}
\hline 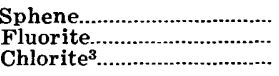 & $0^{0} .2$ & $0^{.4}$ & $\begin{array}{l}0 \\
0 \\
0\end{array}$ & $\begin{array}{l}0^{\text {Tr. }} \\
0\end{array}$ & $\begin{array}{l}1.6 \\
0 \\
.4\end{array}$ & $\begin{array}{l}2.6 \\
0 \\
0\end{array}$ & $\begin{array}{l}0 \\
0 \\
0\end{array}$ & $\begin{array}{l}{ }_{0}^{0} \\
{ }_{.6}\end{array}$ & $\begin{array}{l}0 \\
0 \\
0\end{array}$ & $\begin{array}{l}0 \\
0 \\
0\end{array}$ & $\begin{array}{l}0 \\
.4 \\
.9\end{array}$ & $\begin{array}{l}\mathbf{0} \\
\mathbf{0} \\
\mathbf{0}\end{array}$ & $\begin{array}{l}0 \\
0 \\
\text { Tr. }\end{array}$ \\
\hline $\begin{array}{l}\text { Epidote }{ }^{3} \\
\text { Hematite (red) } \\
\text { Calcite }^{3}\end{array}$ & $\begin{array}{l}\mathbf{0} \\
0 \\
0\end{array}$ & $\begin{array}{l}0 \\
0 \\
0\end{array}$ & $\begin{array}{l}1.3 \\
0 \\
0\end{array}$ & $\begin{array}{l}.9 \\
0\end{array}$ & $\begin{array}{l}0 \\
0 \\
0\end{array}$ & $\begin{array}{l}0 \\
0 \\
0\end{array}$ & ${ }_{0}^{0} .2$ & $\begin{array}{l}0 \\
0 \\
0\end{array}$ & $\begin{array}{l}0 \\
0 \\
0\end{array}$ & $\begin{array}{l}\mathbf{0} \\
\mathbf{0} \\
\mathbf{0}\end{array}$ & $\begin{array}{l}.2 \\
0 \\
0\end{array}$ & $\begin{array}{l}3.2 \\
0 \\
0\end{array}$ & $\begin{array}{l}1.2 \\
0 \\
\mathrm{Tr} .\end{array}$ \\
\hline Total ............................ & 100.0 & 100.2 & 100.2 & 100.3 & 100.2 & 100.2 & 100.2 & 100.5 & 100.2 & 100.0 & 100.0 & 100.0 & 100.2 \\
\hline \multicolumn{14}{|c|}{ Semiquantitative spectrographic analyses for minor constituents (parts per million) } \\
\hline 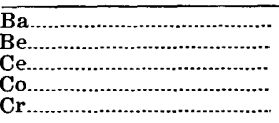 & $\begin{array}{r}200 \\
5 \\
100 \\
<1 \\
<3\end{array}$ & $\begin{array}{r}200 \\
5 \\
150 \\
<1 \\
<3\end{array}$ & $\begin{array}{r}1,000 \\
1 \\
<100 \\
3 \\
5\end{array}$ & $\begin{array}{r}700 \\
1 \\
<100 \\
7 \\
<3\end{array}$ & $\begin{array}{r}150 \\
<1 \\
<100 \\
50 \\
150\end{array}$ & $\begin{array}{r}200 \\
<100 \\
50 \\
200\end{array}$ & $\begin{array}{r}2,000 \\
1 \\
300 \\
50 \\
<3\end{array}$ & $\begin{array}{r}500 \\
1 \\
<100 \\
20 \\
20\end{array}$ & $\begin{array}{r}300 \\
3 \\
300 \\
15 \\
50\end{array}$ & $\begin{array}{r}1,000 \\
1 \\
<100 \\
3 \\
<3\end{array}$ & 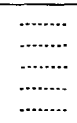 & $\begin{array}{r}700 \\
<100 \\
7 \\
20\end{array}$ & $\begin{array}{r}700 \\
<1 \\
<100 \\
5 \\
7\end{array}$ \\
\hline 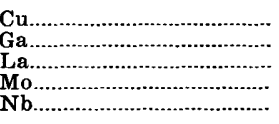 & $\begin{array}{r}2 \\
15 \\
50 \\
3 \\
20\end{array}$ & $\begin{array}{r}7 \\
30 \\
100 \\
3 \\
30\end{array}$ & $\begin{array}{r}10 \\
15 \\
<30 \\
<3 \\
7\end{array}$ & $\begin{array}{r}30 \\
20 \\
50 \\
<3 \\
7\end{array}$ & $\begin{array}{r}300 \\
15 \\
<30 \\
3 \\
<3\end{array}$ & $\begin{array}{r}50 \\
15 \\
<30 \\
5 \\
<3\end{array}$ & $\begin{array}{r}100 \\
20 \\
100 \\
5 \\
<3\end{array}$ & $\begin{array}{r}20 \\
15 \\
<30 \\
3 \\
10\end{array}$ & $\begin{array}{r}7 \\
15 \\
100 \\
<3 \\
20\end{array}$ & $\begin{array}{r}5 \\
20 \\
<30 \\
<3 \\
7\end{array}$ & (...... & $\begin{array}{r}2 \\
15 \\
<30 \\
<3 \\
<3\end{array}$ & $\begin{array}{r}15^{.7} \\
<30 \\
<3\end{array}$ \\
\hline 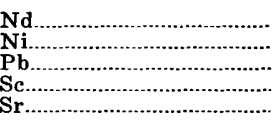 & $\begin{array}{r}<100 \\
<30 \\
15 \\
3 \\
50\end{array}$ & $\begin{array}{r}100 \\
<30 \\
20 \\
<1 \\
50\end{array}$ & $\begin{array}{r}<100 \\
<30 \\
30 \\
10 \\
150\end{array}$ & $\begin{array}{r}<100 \\
<30 \\
15 \\
10 \\
200\end{array}$ & $\begin{array}{r}<100 \\
70 \\
10 \\
50 \\
\mathbf{7 0 0}\end{array}$ & $\begin{array}{r}<100 \\
70 \\
<1 \\
70 \\
300\end{array}$ & $\begin{array}{r}<100 \\
<30 \\
<1 \\
30 \\
500\end{array}$ & $\begin{array}{r}<100 \\
<30 \\
2 \\
20 \\
150\end{array}$ & $\begin{array}{r}<100 \\
<30 \\
30 \\
10 \\
100\end{array}$ & $\begin{array}{r}<100 \\
<30 \\
10 \\
10 \\
150\end{array}$ & $\begin{array}{ll}\ldots \ldots . . . \\
\cdots \cdots \cdots . . \\
\cdots \cdots \cdots . . \\
\cdots \cdots . . .\end{array}$ & $\begin{array}{r}<100 \\
7 \\
10 \\
7 \\
1,000\end{array}$ & $\begin{array}{r}<\mathbf{1 0 0} \\
<30 \\
5 \\
5 \\
5 \\
1,000\end{array}$ \\
\hline 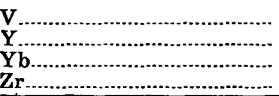 & $\begin{array}{r}10 \\
50 \\
5 \\
150\end{array}$ & $\begin{array}{r}<1 \\
100 \\
10 \\
200 \\
\end{array}$ & $\begin{array}{r}15 \\
30 \\
3 \\
300 \\
\end{array}$ & $\begin{array}{r}15 \\
50 \\
3 \\
300 \\
\end{array}$ & $\begin{array}{r}200 \\
20 \\
3 \\
70\end{array}$ & $\begin{array}{r}500 \\
30 \\
3 \\
70\end{array}$ & $\begin{array}{r}200 \\
50 \\
5 \\
300\end{array}$ & $\begin{array}{r}100 \\
30 \\
3 \\
200\end{array}$ & $\begin{array}{r}70 \\
50 \\
5 \\
200\end{array}$ & $\begin{array}{r}<1 \\
70 \\
7 \\
300\end{array}$ & ….. & $\begin{array}{r}30 \\
7 \\
<1 \\
7\end{array}$ & $\begin{array}{r}20 \\
<3 \\
200\end{array}$ \\
\hline
\end{tabular}

1Density : Densities of both metamorphic rocks (this table) and igneous rocks (table 5) were measured with an air pycnometer. Because volume and weight of the specimens were determined directly, the quotient obtained by dividing the weight by the volume is the density, by definition. Use of the air pycnometer is discussed by McIntyre, Welday, and Baird (1965). The average of three measurements of volume was used in our determinations. Accuracy of measurement was maintained by frequent standardization by use of a steel sphere of known volume. For the metamorphic rocks, where pore space is minimal, both bulk and the metamorphic rock. Most density determinations hve an error limit of $0.004 \mathrm{c} / \mathrm{cm}^{3}$; $\mathrm{r}$ less. Pore with alteration; hence, powder densities of these rocks were almost invariably greater than their bulk densities by as much as $0.1 \mathrm{~g} / \mathrm{cm}^{3}$. Powder densities, thus, are reported for the Tertiary igneous rocks (table 5 ).

${ }^{2} \mathrm{Felsic}-\mathrm{mafic}$ index $=\frac{\mathrm{SiO}_{2}+\mathrm{Na}_{2} \mathrm{O}+\mathrm{K}_{2} \mathrm{O}}{\mathrm{FeO}+\mathrm{Fe}_{2} \mathrm{O}_{3}+\mathrm{MgO}+\mathrm{CaO}}$. See p. 34-35 for explanation of use of this index.

sSecondary minerals.

SAMPLE LOCALITIES

1. SW $1 / 4$ sec. 11, T. 9 N., R. 84 W.

. Summit of hill 9463 , half a mile north of

3. S1/2 sec. 36 , T. 10 N., R. 85 W

4. NW $1 / 4$ sec. 2, T. 9 N., R. 84 W
5. SW $1 / 4$ sec. 3 , T. 9 N., R. 84 W

6. Center of sec. 10, T., 9 N., R. 84 W.

7. NW1/4 sec. 3, T. 9 N., R. 85 W.

9. SE$^{1 / 4}$ sec. 3 , T. 9 N., R. 85 W.
10. SE $1 /$ sec. 7, T. 9 N., R. 84 W.

$8,500 \mathrm{ft}$ N. $8^{\circ}$ E. of summit of Farwell

12. SWountain. 12 sec. 12,9 N., R. $84 \mathrm{~W}$.

12. SW1/4 sec. 12, T. 9 N., R. 84 W. 84 W. 
aspect of this rock is the elongation of the pebbles and cobbles, which gives the rock an unmistakable lineation. The clasts tend to be angular, but many are rounded. They are variable in size; the largest are several tens of centimeters in length.

The clasts are very fine grained felsic gneiss consisting of quartz, microcline, oligoclase, and small amounts of biotite. The matrix of the conglomerate is rich in hornblende and biotite. Very small rounded grains of apatite and zircon are common in both clasts and matrix.

\section{BIOTITE GNEISS}

Biotite gneiss occurs as a mappable unit in the southeast quarter of the Hahns Peak quadrangle and in the adjacent southwest quarter of the Farwell Mountain quadrangle. A long thin layer of biotite gneiss also crops out in the center of the Farwell Mountain quadrangle on the east flank of Farwell Mountain. This layer is an interbed in felsic gneiss and is almost 1 mile long, though its maximum width is only 100 feet. Smaller bodies of biotite gneiss are interbedded in the felsic gneiss complex, in the amphibolite complex, and, to a lesser extent, in the other metasedimentary rock units.

The biotite gneiss unit is variable in its biotite content from about 10 to about 50 percent. Parts of the unit also contain some felsic gneiss and amphibolite. Contacts of biotite gneiss with amphibolite, felsic gneiss, felsic gneiss complex, and schist are almost all gradational. An aspect of the biotite gneiss that deserves emphasis is its gradual change toward a less biotitic, more felsic rock, from west to east.

In general, the biotite gneiss appears as a dark-gray heavy rock. Grain size is very fine, averaging $0.1-0.2 \mathrm{~mm}$. Because of the very fine grain size, hornblende content is commonly difficult to ascertain in the field, and thin-section study becomes necessary. Foliation in much of the unit is difficult to see, but it is present in almost all of it. In less mafic varieties, heavy-mineral streaks are locally present.

Principal minerals of the biotite gneiss are biotite, plagioclase, and quartz; only one specimen (field loc. 3, table 1) contained no quartz. The plagioclase ranges from albite to andesine. Garnet is common locally, but sillimanite and staurolite are rare. Microcline appears in the less mafic samples. Hornblende, muscovite, and chlorite occur locally. Most accessory minerals are black opaques and apatite. Zircon and sphene are less common, and tourmaline was found in only two specimens; calcite is rare.

Chemical, modal, and spectrographic analyses and densities of two samples of biotite gneiss are given in table 1 . 


\section{SCHIST}

Schist crops out in the southeastern part of the Hahns Peak quadrangle, in the southwestern part of the Farwell Mountain quadrangle, and near the center of sec. 13, T. 10 N., R. 85 W. A body of muscovite schist, too small to be mapped at the $1: 24,000$ scale, crops out near a tunnel 1.13 miles east-southeast of Farwell Lake. Interbeds of biotite schist occur commonly in the biotite gneiss, the felsic gneiss complex, and the amphibolite complex.

In general, the schist is fine grained $(0.2 \mathrm{~mm})$ and displays a characteristic sheen on foliation surfaces, owing to its muscovite content. In areas where outcrops are poor or absent, abundant tiny flakes of muscovite in the soil indicate underlying schist bedrock. The muscovite schist surrounding the quartzite and, in fact, most of the schist in the Hahns Peak quadrangle is very quartzose, containing only minor amounts of plagioclase and only sparse microcline. At the south summit of Lester Mountain, light-colored felsic lenses of schist containing microcline are irregularly banded within darker muscovite-biotite schist. Contact of the schist with biotite gneiss to the north is gradational. The schist in the southwestern part of the Farwell Mountain quadrangle contains both plagioclase and microcline and is similar in composition to the felsic gneiss. In general, the schist gradually becomes more like the felsic gneiss to the east.

Garnets and pea-sized or smaller whitish clots of sillimanite are common constituents of the schist ; staurolite is less common. Nonetheless, staurolite is abundant in the saddle in the north-central part of sec. 10, T. 9 N., R. $85 \mathrm{~W}$. The overall composition of the schist in the mapped area suggests that the schist may be a metamorphosed sandy shale. Detrital tourmaline (dichroic, from dark olive drab to pale $\tan$ ), as well as apatite, zircon, and black opaque minerals, is fairly common in the schist.

Crossbedding was seen in the schist, just southeast of the north end of the quartzite body in the $\mathrm{NW}^{1 / 4}$, sec. 2 , T. 9 N., R. $85 \mathrm{~W}$., and on the nose of a ridge in the SW. cor. sec. 35, T. 10 N., R. 85 W. Bedding at both localities is right side up and parallel to foliation.

Chemical analyses, densities, modal analyses, and spectrographic analyses of two samples of schist are given in table 1 .

In the south-central part of sec. 11, T. 9 N., R. 85 W., there is a sequence of very fine grained dense gray schistose rocks that weathers pale pink. Thin-section and X-ray studies indicate that the rocks consist of hornblende, quartz, oligoclase-andesine, chlorite, microcline, pyrophyllite, biotite, muscovite, and rutile. The pyrophyllite, which is considered to be primary, may indicate a metamorphic facies, resulting from a slightly lower temperature than that of the almandine-amphibolite facies. 
QUARTZITE

The largest outcrop of quartzite is in a doubly plunging tightly folded syncline between Lester Creek Reservoir and Willow Creek. The outcrop is about 4,700 feet long and varies in width from about 160 feet to probably more than 200 feet. Steep cliff faces and large broken blocks of the quartzite are exposed in the entrance to Willow Creek Canyon, in the southern part of sec. 3, T. 9 N., R. 85 W. Several smaller bodies of quartzite crop out south of the main body. An outcrop just south of the knob near the center of sec. 10, T. 9 N., R. $85 \mathrm{~W}$., contains minor amounts of specular hematite. Contact of the quartzite with the enclosing muscovite schist is gradational. At the transition between these two rocks, a micaceous sandstonelike rock is characteristically found. Heavy-mineral streaks and crossbedding are seen at the south end of the main quartzite body. Bedding, parallel to foliation, shows a tightly folded syncline at the northeast end of the body.

Most of the quartzite is very hard, resistant, and pale reddish gray. Almost all the grains range in maximum dimension from 0.05 to $0.25 \mathrm{~mm}$. Modal analysis of three specimens showed the quartz content to range from 73 to 87 percent. Muscovite formed 17 percent of one sample, and chlorite made up 15 percent of another. Hematite makes up 13 percent of the quartzite on the knoll in the center of sec. 10. Hornblende and biotite generally make up less than 5 percent of the rock. Accessory minerals, all occurring in only trace amounts, are plagioclase, calcite, apatite, zircon, and tourmaline. The tourmaline is dichroic from olive green to very pale olive drab.

\section{AUGEN GNEISS}

A large area in the north-central part of the Farwell Mountain quadrangle is underlain by augen gneiss. The augen gneiss is typically pink to red, with elongated pink feldspar and quartz porphyroblasts (augen), roughly $1 \mathrm{~cm}$ (centimeter) in size, set in a fine- to medium-grained matrix of quartz, feldspar, and mica. The texture is cataclastic, as shown by the small crushed grains of quartz and feldspar surrounding the porphyroblasts (mortar structure). Quartz and feldspar show intense oscillatory extinction, indicating that the rocks have been strained. Albite twin lamellae are commonly curved and bent.

Compositionally, the augen gneiss is similar to the felsic gneiss. Principal minerals are quartz, microcline, and plagioclase (albite to oligoclase). Perthite and antiperthite are both common; biotite or muscovite, or both, are also commonly present; and, in some samples, secondary epidote and chlorite are present. Accessory minerals are black opaque minerals, zircon, apatite, and, locally, sphene. 
Colorless fluorite was found in the sample from field locality $49 \mathrm{~A}$, for which a modal analysis is given in table 1 .

Most contacts with surrounding felsic gneiss and amphibolite are gradational. At the joint symbol 7,400 feet N. $36^{\circ}$ E. of Farwell Lake (pl. 1), apparent interlayering, parallel to foliation, of augen gneiss with finer grained felsic gneiss was noted. Contact with the amphibolite complex just north of Farwell Creek, on the other hand, is rather sharp on the nose of a large west-southwest-plunging syncline, suggesting that at that locality the contact is an intrusive one.

QUARTZ DIORITE GNEISS

A large body of quartz diorite gneiss crops out in the extreme southeast corner of the Farwell Mountain quadrangle, and a lens of quartz diorite gneiss surrounded by amphibolite complex is exposed in the center of the south half of the same quadrangle. The rock is a medium-grained light-gray distinctive gneiss that has rather narrow limits of composition. Its foliation is commonly weak; parts of the gneiss are homogeneous and have a plutonic aspect.

Average grain size is $1-3 \mathrm{~mm}$; however, grain size varies greatly. The texture is hypautomorphic-granular. Principal minerals are quartz and plagioclase (calcic oligoclase). Microcline was found in minor amounts in some specimens. Biotite and hornblende are commonly present, epidote is a common secondary mineral, and calcite and chlorite are less abundant. Apatite and black opaque minerals are the usual accessory minerals.

Chemical, modal, and spectrographic analyses and densities for two specimens of quartz diorite gneiss are given in table 1.

\section{ALTERED GNEISS WITH DARK-GRAY QUARTZ AND} GARNET-EPIDOTE SKARN

Altered gneiss occupies a small area about 1 mile east of the center of the Farwell Mountain quadrangle. Most of the rock is fine grained and variable in composition. The altered gneiss is characterized by epidote and brown garnet (andradite) that tend to form irregular segregations. Quartz, microcline, and plagioclase are generally present, and hornblende and pyroxene (diopside) are present but less abundant. Black opaque minerals, sphene, and zircon are common accessory minerals.

The altered gneiss contains several lenslike bodies of massive quartz. The quartz contains segregations of andradite or epidote or hornblende. Close-set fractures are everywhere present and are parallel with foliation in the enclosing altered gneiss. Characteristically, the color of the quartz varies from dark blue gray to dark smoky gray, but in some small areas the quartz is milky white. Grain size of the quartz is variable; the average size is about 3 
$\mathrm{mm}$, but many grains are $1 \mathrm{~cm}$ or larger. In thin section the quartz is colorless, and its grains, which tend to be elongate and fractured, show undulatory extinction. Accessory minerals in trace amounts are epidote, hornblende, and black opaque minerals.

A lens of silicated carbonate rock in the gneiss has a very etched, irregular surface in outcrop, owing to solution of part of the carbonate. Major minerals are calcite, andradite, wollastonite, quartz, and, locally, epidote. This skarn assemblage has a granular texture and has an average grain size of about $0.4 \mathrm{~mm}$.

Locally, coarse segregations of epidote, hornblende, and calcite are found in hydrothermally altered zones of amphibolite or felsic gneiss. Prospect pits mark some of these sites, which are too small to be mapped separately. Near the NE. cor. sec. 3, T. 9 N., R. 84 W, (near Boulder Park in the Farwell Mountain quadrangle), there is a 12 - by 40 -foot boudinlike body of garnet, hornblende, epidote, and quartz. On the slope southeast of the Elk River, near the center of the N1/2 sec. 10, T. 9 N., R. 84 W., there are 8-foot blocks of almost pure garnet.

\section{PEGMATITE}

Pegmatite is fairly common in all the Precambrian rocks, except the quartzite; however, only the largest bodies of pegmatite are shown on the map. In the two quadrangles, about 12 of these are more than 500 feet long. Both crosscutting and conformable relations are evident.

The pegmatites are generally of the simple type consisting of quartz, feldspar, and a small amount of mica. A small pegmatite in the SE. cor. sec. 4, T. 9 N., R. 84 W., near Boulder Park, Farwell Mountain quadrangle, contains magnetite crystals as much as 2 inches across. Other minerals infrequently seen in the pegmatites are green chlorite and specular hematite.

\section{AGE}

Rubidium-strontium age determinations were made on four samples of felsic gneiss and on three samples of augen gneiss from the area. Data from these determinations are given in table 2. According to C. E. Hedge (written commun., Feb. 10, 1970), who made the determinations, "On an isochron plot of these data, the felsic gneisses define an excellent line indicating an age of 1,650-1,700 m.y. (million years). The augen gneisses scatter a little around this line. I interpret the augen gneisses as being approximately the same age as the felsic gneisses, but they appear to be showing some response to a later thermal event."

Three potassium-argon age determinations were made on minerals that were separated from the Precambrian rocks of the area. Results are shown in table 3. According to R. F. Marvin, who was 
TABLE 2. - Rubidium-strontium data on felsic gneiss and augen gneiss [Localities are shown on pl. 1. Analyst, C. E. Hedge]

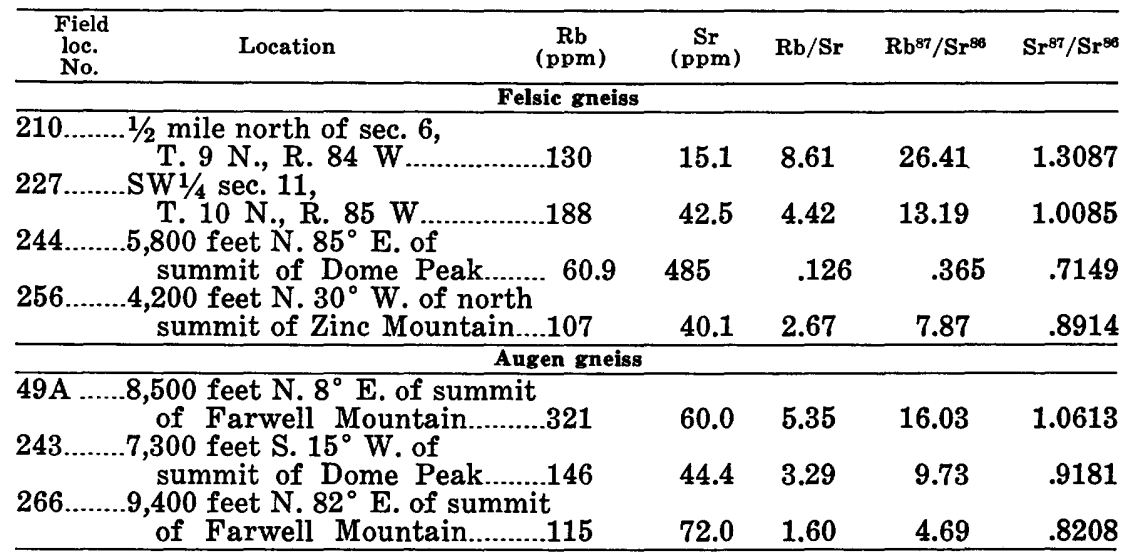

TABLE 3.- Potassium-argon ages of minerals that were separated from Precambrian rocks

[Field localities are shown on pl. 1. Analysts: R. F. Marvin, H. H. Mehnert, and Violet Merritt]

Decay constants: $\quad K^{40} \lambda_{\varepsilon}=0.585 \times 10^{-10}$ per yr; $\quad$ Atomic abundance: $\mathrm{K}^{40}=1.19 \times 10^{-4}$.

$\lambda_{\beta}=4.72 \times 10^{-10}$ per $\mathrm{yr}$.

\begin{tabular}{|c|c|c|c|c|c|c|c|}
\hline Mineral & $\begin{array}{l}\text { Field } \\
\text { loc. } \\
\text { No. }\end{array}$ & $\begin{array}{c}\text { Rock type } \\
\text { and } \\
\text { location }\end{array}$ & $\begin{array}{l}\mathrm{K}_{2} \mathrm{O} \\
\text { (per- } \\
\text { cent) }\end{array}$ & $\begin{array}{l}\text { Arto }^{40} \\
\left(10^{-10}\right. \\
\text { moles/ } \\
\text { gram })\end{array}$ & $\begin{array}{l}\text { Radio- } \\
\text { genic } \\
\text { Arto } \\
\text { (per- } \\
\text { cent) }\end{array}$ & $\mathrm{Ar}^{40} / \mathrm{K}^{\text {t6 }}$ & $\begin{array}{c}\text { Age } \\
\text { (m.y.) }\end{array}$ \\
\hline Muscovite........ & $1 \mathrm{M}$ & $\begin{array}{l}\text { Pegmatite within } \\
\text { felsic gneiss, } \\
\text { Farwell mine, } \\
\text { sec. 11, T. } 10 \text { N., } \\
\text { R. } 85 \text { W. }\end{array}$ & 8.64 & 345.2 & 99 & 0.158 & $1,680 \pm 50$ \\
\hline Hornblende.... & 257 & $\begin{array}{l}\text { Hornblende gneiss, } \\
\text { sec. } 34, \mathrm{~T} \text {. } 10 \mathrm{~N} . \\
\text { R. } 85 \mathrm{~W} \text {. }\end{array}$ & .53 & 18.17 & 98 & .136 & $1,510 \pm 100$ \\
\hline Scapolite........... & 257 & 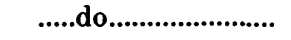 & .15 & 3.155 & 64 & .0833 & $1,060 \pm 200$ \\
\hline
\end{tabular}

in charge of making the determinations, the 1,060-m.y. age for the scapolite is unduly low, because the structure of the scapolite crystal probably permits leakage of radiogenic argon. The age determination on the hornblende $(1,510$ m.y.) corresponds to the ages determined on hornblende from the Idaho Springs Formation in the northeastern Front Range, Colo. (Peterman and others, 1968). However, a more valid age of the metamorphism is probably represented by the age determined on the muscovite $(1,680$ m.y. $)$. The coarsely crystalline muscovite-as occurs in pegmatite-especially permits retention of radiogenic argon.

The age of regional metamorphism of Precambrian rocks in the Hahns Peak and Farwell Mountain quadrangles is similar to that in the Front Range, where a measure of this age has been deter- 
mined by radiometric dating of the Boulder Creek Granite-a syntectonic intrusion-to be 1,700-1,800 m.y. old (Peterman and others, 1968). The large, appreciably younger Precambrian intrusions known to exist east and south of the Hahns Peak and Farwell Mountain quadrangles are absent in the study area.

\section{PERMIAN AND LOWER TRIASSIC ROCKS \\ GOOSE EGG AND RED PEAK FORMATIONS}

Red calcareous siltstone and fine-grained sandstone rest with great angular unconformity on Precambrian gneiss at three localities in the Farwell Mountain quadrangle: along lower Coulton Creek, near the SW. cor. sec. 5, T. 9 N., R. 84 W.; along upper Hinman Creek, in the northcentral part of the quadrangle; and at the headwaters of King Solomon Creek, in the northwestern part of the quadrangle. These rocks are believed to be assignable to the Permian Goose Egg Formation and the Lower Triassic Red Peak Formation. In the report area, exposures are small and discontinuous, although, a short distance to the south, the Goose Egg and Red Peak Formations are at least 285 feet thick (Hunter, 1955, p. 71). There, the rock unit is overlain by the Jelm Formation, but the base of the Goose Egg Formation is not exposed. Owing to both the paucity of outcrops and the similarity of lithologies, the Goose Egg and Red Peak Formations are not differentiated on plate 1 from the overlying Jelm and Popo Agie Formations.

\section{UPPER TRIASSIC AND PRE-MORRISON JURASSIC ROCKS}

By G. N. Pipiringos

Upper Triassic and pre-Morrison Jurassic rocks that overlie the Permian and Triassic rocks are either concealed or poorly exposed throughout the area, except at one locality on the north side of Hahns Peak, where most of the Jurassic rocks are well exposed (figs. 3, 4, loc. 96). Extent of outcrops within the mapped area is inadequate for determination of the stratigraphic units that are present or of their thickness, lithology, and stratigraphic relations. However, inasmuch as the stratigraphic units are exposed along the Roaring Fork of the Little Snake River in Wyoming, about 14 miles north of Hahns Peak, and at Clark, Colo., about 8 miles to the south (locs. 65 and 95, figs. 3, 4), the units that are present, their thickness, lithology, and other attributes can be inferred with reasonable certainty. The average aggregate thickness of the Upper Triassic and pre-Morrison Jurassic rocks in the mapped area is probably about 400 feet. The Triassic(?) Nugget Sandstone and the Triassic Jelm and Popo Agie Formations are mapped together with the underlying Goose Egg and Red Peak Formations as a single unit, representing strata with a total thickness of 685 feet in 
the Hahns Peak and Farwell Mountain quadrangles. The Jurassic Sundance and Morrison Formations are also undifferentiated on the map (pl. 1), owing to poor exposure.

The correlation and nomenclature of Triassic and Jurassic rocks in the Hahns Peak and adjacent areas cannot be discussed independently from the overall problem of correlation and nomenclature of Jurassic and Triassic rocks along the entire length of the west flank of the Sierra Madre-Park Range uplift. Nomenclature generally used for these rocks north of the Hahns Peak and Farwell Mountain quadrangles differs from that used south of them. The nomenclature used north of the quadrangles - in south-central Wyoming - was established by Pipiringos (1968), and the nomenclature used south of the quadrangles-in north-central Colorado-was established by Pipiringos, Hail, and Izett (1969) and by Poole and Stewart (1964). Restored sections (figs. 3, 4) show the stratigraphic relations from south-central Wyoming southward to the vicinity of State Bridge, in north-central Colorado. Stratigraphic sections on which the restored sections are based are listed in table 4 .

On the basis of the correlations shown in the restored sections (fig. 3), the Triassic rocks of the mapped area are assigned, in ascending order, to the Jelm Formation of Late Triassic age, the Popo Agie Formation of Late Triassic age, and the Bell Springs Member of the Nugget Sandstone of Triassic ( ?) age. The pre-Morrison Jurassic rocks are assigned to the Sundance Formation of Late Jurassic age. Just south of the mapped area, the Jelm Formation pinches out, and from there southward, Triassic rocks younger than the Jelm should be referred to the Chinle Formation, as shown on the right side of figure 3 .

Stratigraphic sections used in constructing figures 3 and 4 were measured by G. N. Pipiringos with the aid of the following persons in the years indicated: section localities 59, 95, and 96-Roland $\mathrm{H}$. Shubert, 1958; locality 56-James W. Mytton, 1960; localities 61, 62, 63, 65, 92, and A-Arthur A. Bookstrom, 1963; and locality 94 -George L. Snyder, 1965. (Also, see table 4.)

JELM FORMATION

The Jelm Formation lies above red beds of Triassic age. At Clark, Colo. (fig. 3, loc. 95), and to the north, the Jelm lies below the Popo Agie Formation, but to the south, it lies beneath rocks similar to the Popo Agie, but which are assigned to the Chinle Formation.

The Jelm consists principally of grayish-red to reddish-brown and purple fine-grained micaceous sandstone that is massive to obscurely bedded and makes rounded ledges where exposed. Its average thickness is probably about 100 feet. An 80-foot section, crossbedded in some places and with pebble conglomerate at the 
20 HAHNS PEAK AND FARWELL MOUNTAIN QUADRANGLES, COLO.

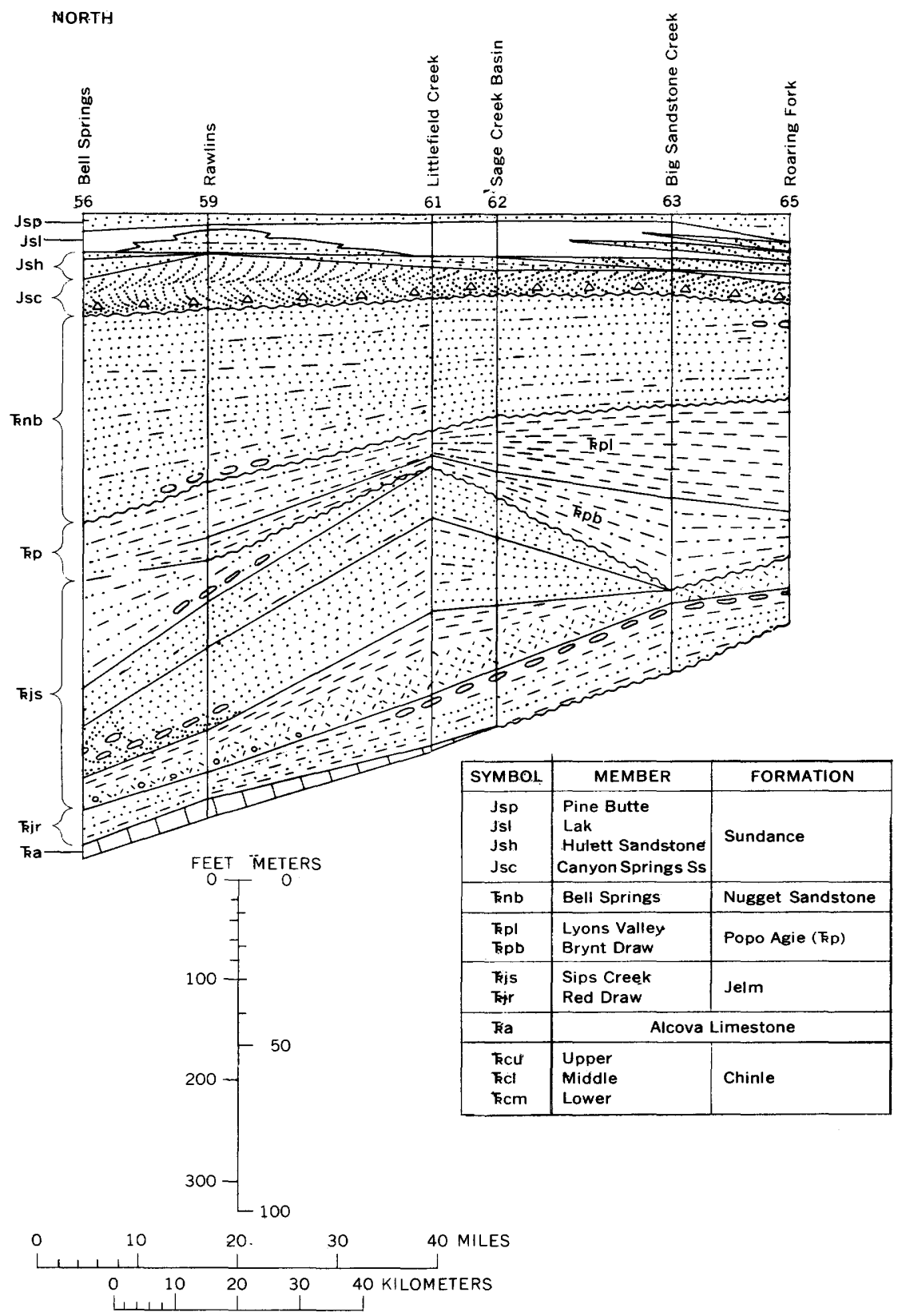

FIGURE 3 (above and facing page). - Restored section showing nomenclature, correlation, dominant lithologies, and unconformities of the Jelm Formation and overlying rocks to the top of the Pine Butte Member of the Sundance Formation in southern Wyoming and north-central Colorado. Placement of Chinle in table is not in stratigraphic sequence; Chinle equals Popo Agie. Line of section is shown in figure 1 . Unconformity is indicated by wavy line. 


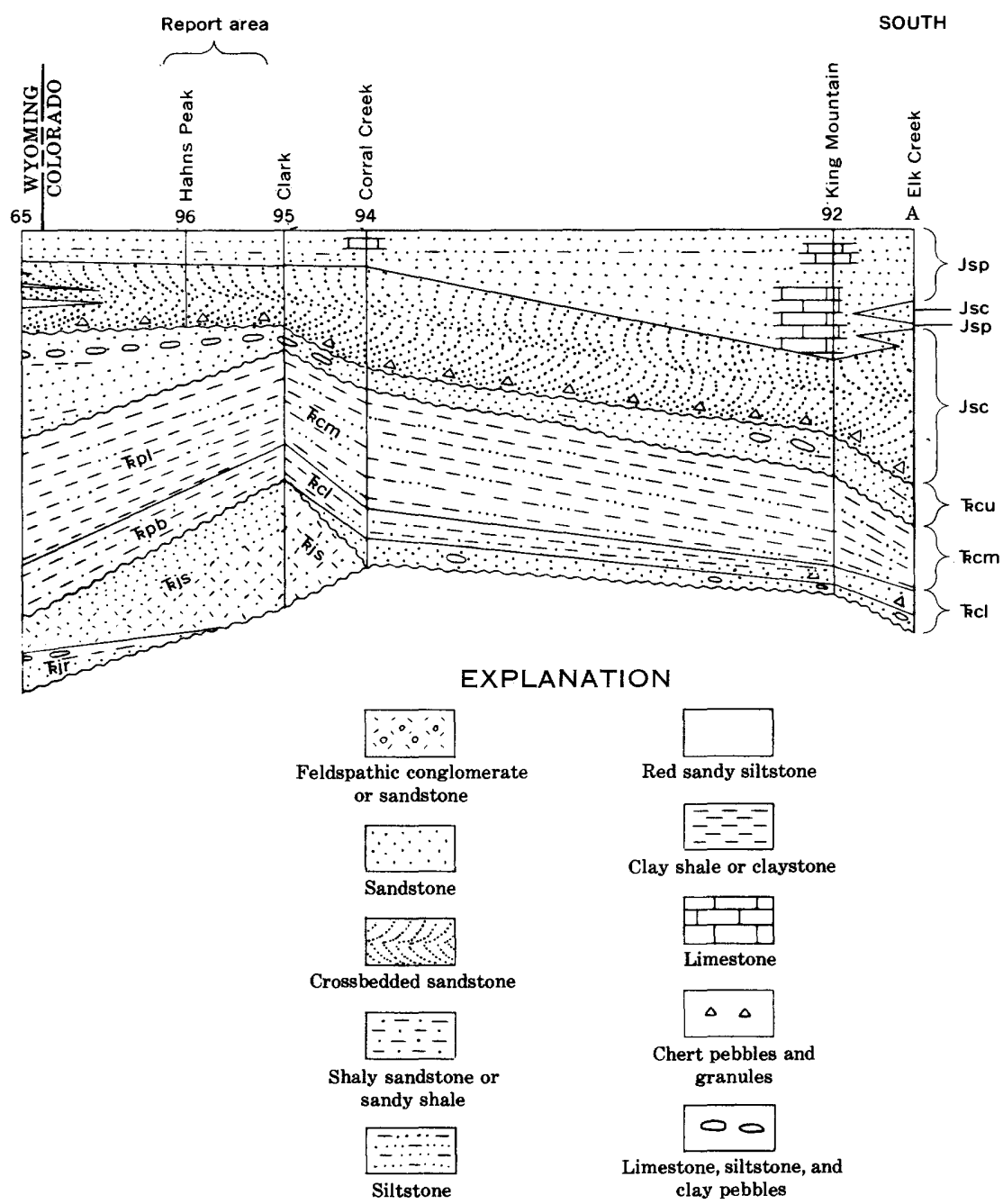

base, was measured along a small eastern tributary of the North Fork Elk River (Murphy, 1958, p. 24-25). There, the top of the section is concealed by glacial debris.

The contact with the underlying red beds of Triassic and Permian(?) age is sharp and regionally unconformable, as at section localities 95 and 65 (fig. 3).

As shown in figure 3 (loc. 96), the Jelm of the mapped area correlates northward with the lower part of the Sips Creek Member of the Jelm, but it disappears southward rather abruptly, very probably as a result of erosion. Inasmuch as equivalents of this unit elsewhere contain wood and bone fragments, shale and siltstone, 


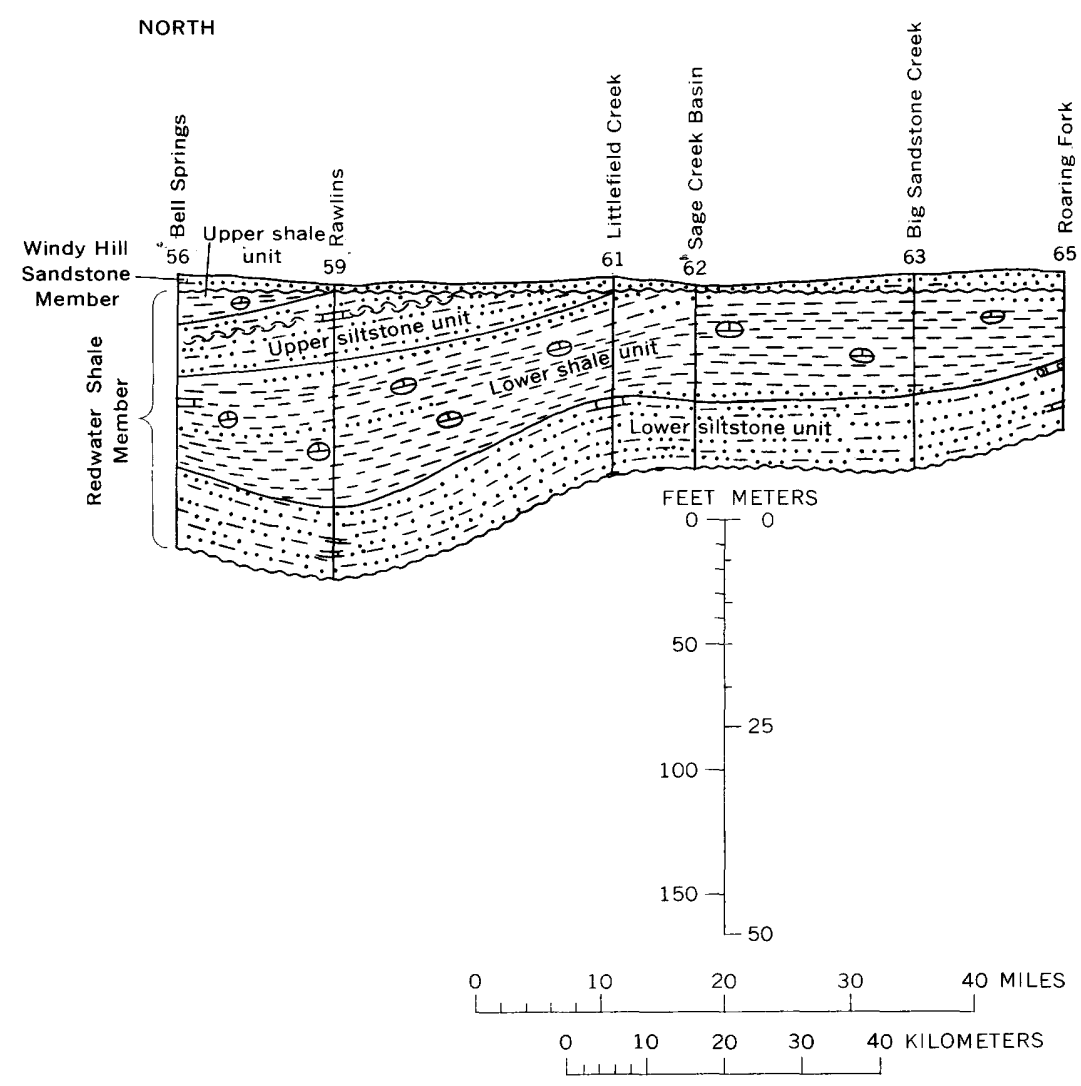

Figure 4 (above and facing page). - Restored section showing nomenclature, correlation, dominant lithologies, and unconformities of the Redwater Shale and Windy Hill Sandstone Members of the Sundance Formation in southern Wyoming and north-central Colorado. Line of section is shown in figure 1. Unconformity is indicated by wavy line.

and limestone-pebble conglomerates, the Jelm in the mapped area probably is entirely of fluviatile origin.

Nowhere have diagnostic fossils ever been found in the Jelm; hence, its exact age is uncertain. It lies below rocks of Late Triassic age; and inasmuch as it lies unconformably on the underlying rocks of Early Triassic age, it may be of Middle Triassic age. Previous workers have thought the Jelm to be of Late Triassic age because of its supposed equivalency with the Popo Agie or with the Chinle Formation; however, work by Pipiringos (1968) has subsequently shown that the Jelm underlies the Popo Agie in south-central Wyoming, and the present work shows that the Jelm most probably underlies the Popo Agie of the Hahns Peak area. 


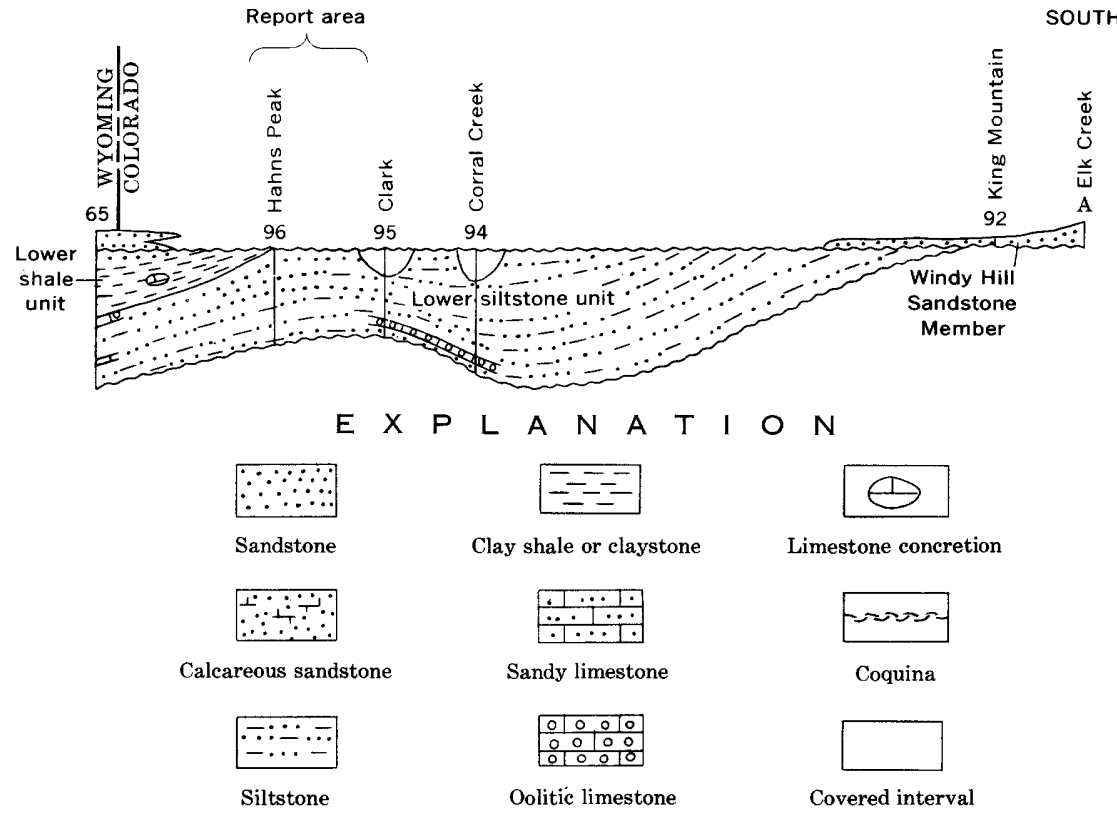

TABLE 4. - Names and locations of stratigraphic sections shown in figures 3 and 4

[Line of stratigraphic sections is shown in fig. 1]

\begin{tabular}{|c|c|c|c|}
\hline \multirow{2}{*}{$\begin{array}{l}\text { Section } \\
\text { loc. } \\
\text { No. }\end{array}$} & \multirow{2}{*}{$\begin{array}{l}\text { Name of } \\
\text { stratigraphic } \\
\text { section }\end{array}$} & \multicolumn{2}{|c|}{ Location } \\
\hline & & Section, township, and range & Quadrangle \\
\hline \multicolumn{4}{|c|}{ Wyoming } \\
\hline $\begin{array}{l}56 \\
59 \\
61\end{array}$ & \multirow{4}{*}{\multicolumn{3}{|c|}{ 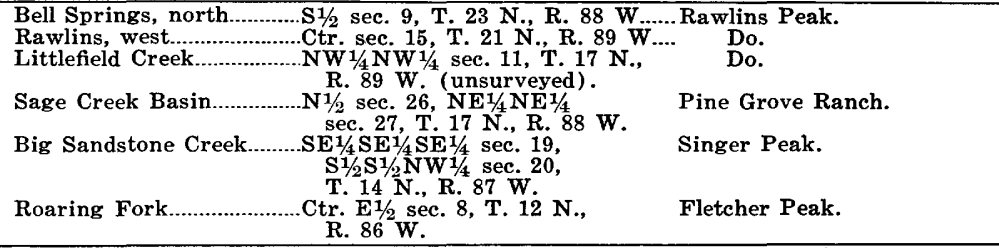 }} \\
\hline 62 & & & \\
\hline 63 & & & \\
\hline 65 & & & \\
\hline \multicolumn{4}{|c|}{ Colorado } \\
\hline 96 & Hahns Peak & 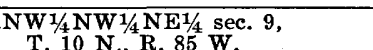 & Hahns Peak. \\
\hline 95 & Clark & $\begin{array}{l}\mathrm{SE}^{1} / 4 \mathrm{NW}^{1} / 4 \text { and } \mathrm{SW} 1 / 4 \mathrm{NE}^{1} / 4 \mathrm{SE}^{1 / 4} \\
\text { sec. } 22 \text { T. } 9 \text { N., R. } 85 \mathrm{~W} .\end{array}$ & Clark. \\
\hline 94 & Corral Creek................ & $\begin{array}{l}\text { NW } 1 / 4 \mathrm{SW}^{1} 1 / 4 \text { sec. } 18, \mathrm{~T} .8 \mathrm{~N} . \\
\mathrm{R} .84 \mathrm{~W}, \mathrm{~W} 1 / 2 \mathrm{NE} 1 / 4\end{array}$ & Floyd Peak. \\
\hline 92 & King Mountain ........... & NW $1 / 4$ SW $1 / 4$ sec. $36, T .1$ N., & $\begin{array}{l}\text { Craig, Colo. } \\
\text { (U,S, Army Man Service). }\end{array}$ \\
\hline $\mathbf{A}$ & Elk Creek & $\begin{array}{l}\text { SW1/4 sec. } 33, \text { T. } 1 \text { S., } \\
\text { R. } 84 \text { W.; NW1/4 sec. } 4 \text {, } \\
\text { T. } 2 \text { S., R. } 84 \text { W. }\end{array}$ & $\begin{array}{l}\text { Leadville, Colo } \\
\text { (U.S. Army Map Service). }\end{array}$ \\
\hline
\end{tabular}

POPO AGIE FORMATION

The Popo Agie Formation of the mapped area includes the Upper Triassic rocks above the Jelm Formation and below the Bell Springs Member of the Nugget Sandstone. 
The Popo Agie Formation of Late Triassic age consists principally of pale-red to purplish-red sandy siltstone and sandstone in the lower part that grades upward into pale-red to purplish-red claystone and silty claystone. Its average thickness is probably about 120 feet.

The contact with the underlying Jelm Formation is generally sharp and regionally unconformable, but it has not been recognized in the poor exposures in the Hahns Peak and Farwell Mountain quadrangles.

As shown in figure 3, the lower part of the Popo Agie of the mapped area correlates with the Brynt Draw Member in south-central Wyoming, and with the upper part of the lower member of the Chinle in north-central Colorado. It is the same as the unit informally designated as the mottled member of the Chinle by Poole and Stewart (1964, fig. 2).

The lower part of the lower member of the Chinle, recognized at section A by Pipiringos, Hail, and Izett (1969, p. N5-N8; fig. 3, this report), correlates with the Gartra Member of the Chinle (Poole and Stewart, 1964, figs. 1, 2) and extends northward to Corral Creek (fig. 3, loc. 94) but cannot be recognized in any of the stratigraphic sections farther north. It probably grades laterally into the Brynt Draw, just as it does into the mottled member locally at many places in northwestern Colorado and northeastern Utah.

The Brynt Draw Member of the Popo Agie and its equivalent, the lower member of the Chinle, locally contain abundant fossil land vertebrates and plant fragments and lenses of feldspathic sandstone; this content indicates a fluviatile environment of deposition. In contrast, the Lyons Valley Member of the Popo Agie and its equivalents are very fine grained siltstone or claystone that apparently is devoid of bedding and uniform in lithology and appearance over wide areas. These features suggest relatively quiet, uninterrupted deposition in a lake.

The upper part of the Popo Agie in the mapped area correlates with the Lyons Valley Member in south-central Wyoming and with the middle member of the Chinle in north-central Colorado. In northwestern Colorado, however, the Lyons Valley is included in the lower part of the unit informally designated as the red siltstone member of the Chinle, and in northeastern Utah it is the same as the unit informally designated as the ocher siltstone member of the Chinle by Poole and Stewart (1964, fig. 2).

\section{BELL SPRINGS MEMBER OF THE NUGGET SANDSTONE}

The Bell Springs Member of the Nugget Sandstone of Triassic (?) age in the mapped area includes rocks that lie above the Popo Agie 
Formation and below the Sundance Formation of Late Jurassic age.

The member consists principally of reddish-brown very fine grained thin-bedded sandstone and reddish-brown siltstone and locally contains purplish limestone concretionary zones. The sandstone weathers to gray slabby or rounded ledges; the siltstone forms reentrant slopes, most of which are covered. The average thickness of the member is probably about 50 feet.

The contact with the underlying Popo Agie Formation is poorly exposed. Although the contact appears to be conformable, it is an unconformity regionally. At many places in Wyoming, Colorado, and Utah, the basal beds of the Bell Springs Member contain ocher claystone pebbles derived from the underlying Lyons Valley Member of the Popo Agie.

The Bell Springs of the mapped area correlates with the type Bell Springs (fig. 3, loc. 56) in Wyoming. It thins southward and apparently constitutes the upper member of the Chinle at stratigraphic section locality A about 10 miles northwest of State Bridge, Colo. (Pipiringos and others, 1969, p. N9, N16). It is equivalent, in part, to the red siltstone member of the Chinle Formation in Colorado (Poole and Stewart, 1964, fig. 2) and to the unit informally designated as the upper member of the Chinle by Kinney (1955, p. 68-69) in northeastern Utah. The Bell Springs thins southward from Wyoming into Colorado, probably owing almost entirely to erosion prior to the deposition of the overlying Sundance Formation.

The environment of deposition of the Bell Springs Member is not certain; some of the member may be fluviatile, as suggested by local intraformational channeling of the sandstone beds, but most of it probably was deposited in an environment similar to a tidal flat, inasmuch as local bedding surfaces show trails of bottom dwellers and asymmetric current ripple marks of low amplitude. The environment of deposition probably was subject to restricted circulation from time to time, inasmuch as the sandstone beds locally contain cubic salt-crystal casts and show mud cracks and curls.

Because the Chinle Formation is of Late Triassic age, the Bell Springs Member of the Nugget, which correlates with the upper part of the Chinle of northwestern Colorado and northeastern Utah, is probably also of late Triassic age.

\section{SUNDANCE FORMATION}

The Sundance Formation in the mapped area includes marine Upper Jurassic rocks that overlie the Bell Springs Member of the Nugget Sandstone and underlie the Morrison Formation of Late 
Jurassic age. The formation consists of sandstone and shale, and its average thickness is probably about 120 feet.

The formation comprises three thin stratigraphic units that constitute, in ascending order, the Canyon Springs Sandstone, the Pine Butte, and the Redwater Shale Members. These units are well exposed within this area at only one locality (figs. 3,4 , loc. 96) on the north side of Hahns Peak (fig. 1).

As shown in figure 3, two other members in the lower part of the Sundance-the Lak, which consists principally of reddish-brown sandy siltstone, and the Hulett, a yellow-weathering greenish-gray sandstone-are present in south-central Wyoming, where they interfinger with and grade southward into the Canyon Springs and the Pine Butte Members, all of Late Jurassic (Callovian) age in southern Wyoming and north-central Colorado. Unlike the underlying Triassic rocks and the overlying Upper Jurassic (Oxfordian) Redwater Shale, the lower part of the Sundance (Callovian) is actually thicker in the vicinity of localities 92 and A than it is nearly everywhere else in all of southeastern Wyoming and northwestern Colorado.

CANYON SPRINGS SANDSTONE MEMBER

The Canyon Springs Sandstone Member consists of light-yellowish-gray to grayish-orange-pink very fine grained sandstone that weathers into massive to obscurely crossbedded cliffs. It probably averages about 60 feet in thickness in the mapped area, where the member is more resistant to erosion than any other rock unit in the Triassic and Jurassic sections. The most complete exposures of Canyon Springs in the two quadrangles are on the north flank of Hahns Peak and in a stream gully 750 feet south of Hinman Lake in the NE1/4 sec. 5, T. 9 N., R. 84 W. The sandstone forms a small hogback near a jeep road east of Farwell Mountain that crosses the divide between Scott Run and Hinman Creek. The member lies above Triassic rocks that are truncated by a chert-pebble and granule-studded erosion surface.

Truncation, associated with this surface of erosion, is most pronounced in sections oriented generally east to west (Pipiringos, 1968, fig 2). This erosion surface is probably the most conspicuous and widespread in the Paleozoic and Mesozoic sequence and is probably the most useful and reliable, inasmuch as it can be identified by the ubiquitous chert pebbles associated with it throughout most of the Rocky Mountain region. Some details of this chert-pebblestudded surface have been published in previous studies (U.S. Geological Survey, 1965; Pipiringos, 1968, p. D19; Pipiringos and others, 1969, p. N11), and others will be published after petrographic (and other) studies are completed.

The Canyon Springs of the Hahns Peak area is overlain by the 
Pine Butte Member. The Canyon Springs is lithologically continuous both with the type Canyon Springs in the Black Hills and with the Entrada Sandstone of northwestern Colorado and northeastern Utah. The type Canyon Springs is of earliest Callovian age, and the Entrada is of middle Callovian age (Imlay, 1947, table 1, p. 230231). Furthermore, Imlay's table 1 shows the Entrada to be of the same age as the Lak Member, which overlies but is separated from the type Canyon Springs by two other members of the Sundance.

Relations shown in figure 3 demonstrate how the Canyon Springs in the Hahns Peak-Corral Creek area (locs. 96-94) can be of middle Callovian age (interfingers with the Lak) and also be continuous northward with a sandstone unit of early Callovian age. The relations shown also extend the range of the age of the Canyon Springs still farther upward, inasmuch as the member interfingers southward with the still younger Pine Butte Member at locality A and at several localities east of $A$. (See Pipiringos and others, 1969, fig. 3.) The deposition of the Canyon Springs Sandstone Member and its equivalents probably spanned a period of time that extended from earliest Callovian in central and northeastern Wyoming to late middle Callovian in north-central Colorado.

PINE BUTTE MEMBER

The Pine Butte Member in north-central Colorado generally overlies, and locally intertongues with, the Canyon Springs Sandstone Member (fig. 3). Farther north in Wyoming it overlies, and locally intertongues with, the red beds of the Lak Member.

In the mapped area the member consists mainly of greenish-gray silty shale that forms slopes interrupted by thin ripple-marked ledges formed by greenish-gray very fine grained sandstone beds. This lithologic character is maintained northward into central Wyoming. Oolitic sandstone and limestone beds are present locally, but are inconspicuous. Fossils consist principally of furrowed trails of bottom-dwelling organisms. To the south oolitic limestone and sandstone beds are predominant and form conspicuous cliffs and ridges. These limestones, which are fairly fossiliferous (containing mainly the oysterlike Lopha), grade eastward into shales and sandstones that are abundantly fossiliferous (containing mainly ostracodes and the trigonid Vaugonia conradi (Meek and Hayden)). Concomitantly, bottom-dweller trails become scarce to absent. The Pine Butte of this area and its fossils are described more fully by Pipiringos, Hail, and Izett (1969, p. N13-N14, N16-N33). In the mapped area the thickness of the Pine Butte probably averages about 30 feet.

The pelecypod Vaugonia conradi (Meek and Hayden) very probably occurs only in Callovian and Middle Jurassic rocks, according 
to Imlay. (See discussion by Pipiringos and others, 1969, p. N13N14.) The fact that the Pine Butte overlies and locally intertongues with the Lak, where both units are present, suggests strongly that the Pine Butte is of the same age as the Lak (middle Callovian). However, it is possible, though less likely, that the Pine Butte is of early late Callovian age.

\section{REDWATER SHALE MEMBER}

The Redwater Shale Member overlies the Pine Butte with regional erosional unconformity. In the mapped area, the Redwater consists of gray glauconitic clayey siltstone and sandstone beds, and it averages about 35 feet thick. But this undoubtedly is not the total original thickness because, at the Hahns Peak locality (fig. 4, loc. 96) - where the contact of the Redwater with the Morrison Formation is well exposed-the member is truncated by a white crossbedded channel sandstone at the base of the Morrison. If similar channeling is common at this contact throughout the mapped area, the average thickness of the Redwater could not be systematically inferred.

As shown in figure 4, only the lower siltstone unit of the Redwater is present in the mapped area, where three stratigraphically higher units of the Redwater have been truncated by the surface of erosion at the base of the Windy Hill Sandstone Member of the Sundance, or at the base of the Morrison Formation where the Windy Hill is absent.

The lower siltstone unit in the mapped area locally contains abundant belemnites. Elsewhere, throughout Wyoming, northwestern Colorado, and northeastern Utah, the lower siltstone unit and its equivalents contain abundant belemnites, many of which are associated with ammonites of the Cardioceras zone of early Oxfordian age. There is little reason to doubt that the basal siltstone unit of the Redwater in the Hahns Peak area is also of early Oxfordian age.

The Redwater Shale Member is truncated by the Windy Hill Sandstone Member south of the report area at some point between localities 94 and 92 (fig. 4).

\section{WINDY HILL SANDSTONE MEMBER}

The Windy Hill Sandstone Member is believed to be absent in the Hahns Peak area, although it is present both to the north and to the south of that area (fig. 4). The sandstone is known to intertongue locally with the Morrison Formation (Pipiringos, 1968, p. D24), and its disappearance south of locality 65 is inferred to be due to intertonguing. (See fig 4.) Also, at least locally, the Windy Hill may be absent because of channeling at the base of the Morrison.

The Windy Hill Sandstone Member is a thin but widespread unit 
of marine- or brackish-water origin. For further details on this unit, the interested reader is referred to Pipiringos (1957, p. 24, member A), Pipiringos (1968, p. D23-D25), and Pipiringos, Hail, and Izett $(1969, \mathrm{p} . \mathrm{N} 15-\mathrm{N} 16)$.

\section{POST-SUNDANCE JURASSIC ROCKS \\ MORRISON FORMATION}

Fluviatile and lacustrine beds disconformably overlie the marine and littoral beds of the Sundance Formation. These strata appear to be unfossiliferous in the mapped area. They were assigned to the Morrison Formation, of Late Jurassic age, because of their lithology and relations to underlying and overlying beds.

The best exposure in the mapped area is on the north side of Hahns Peak, where the formation consists of a lower unit of sandstone that is $\mathbf{7 5}$ feet thick and contains clay galls and an upper unit of thin-bedded claystone and fresh-water limestone that is 192 feet thick (Barnwell, 1955, p. 73). The formation is distinctively and characteristically variegated-colors tend to be alternately greenish gray and reddish brown. On the west side of Hahns Peak, in an erosional window framed by the overlying Dakota Sandstone, the Morrison is bleached almost white from hydrothermal alteration. Because exposures of Jurassic rocks in the Hahns Peak and Farwell Mountain quadrangles are poor, except for the north side of Hahns Peak, the Morrison Formation is not distinguished on the map from the underlying Sundance Formation; the undifferentiated map unit represents beds totaling about 315 feet thick.

The Morrison Formation is the least exposed rock unit in the report area, not only because the soft claystone beds readily disintegrate, but because the upper part is typically covered by float blocks of indurated Dakota Sandstone. Along the north side of the jeep road between the North Fork Elk River and Hinman Creek, the hillslopes eroded in the Morrison are coated with green- and red-tinted mud that is littered with thin limestone slabs. In the early summer, when the terrane is wettest, mudflows of Morrison material frequently block a logging road in the eastern part of the Farwell Mountain quadrangle, near English and Lost Dog Creeks.

\section{CRETACEOUS ROCKS}

DAKOTA SANDSTONE

The Dakota Sandstone, which consists mostly of light-gray wellcemented crossbedded sandstone and pebble conglomerate, is the most resistant sedimentary unit in the region, and it tends to form a protective cap over the easily erodable, clayey Morrison Formation. The areal extent and abundance of the Dakota outcrops are greatly out of proportion to the stratigraphic thickness of only 90-125 feet. 
The thickest complete exposed section in the mapped area is that of lower Trail Creek, in the north-central part of the Farwell Mountain quadrangle. There, a lower conglomeratic member, 60 feet thick, and an upper sandy member, 61 feet thick, are separated by a 2-foot-thick shale member (Murphy, 1958, p. 29-31). The conglomerate is replete with well-rounded chert, quartz, and quartzite pebbles. Westward through the Hahns Peak quadrangle, the sandstone members become thinner, and the shale disappears. The name Cloverly Formation was used by the University of Wyoming geologists in their mapping of the region for the rocks which are called Dakota Sandstone in this report. The Dakota Sandstone, as mapped in the Hahns Peak region, corresponds wholly, or at least in part, to the Lytle Formation of the Dakota Group of the eastern Front Range, which, on the east flank of the Park Range, about 15 miles east of the Farwell Mountain quadrangle, consists of 60-150 feet of sandstone and conglomerate topped by claystone (Hail, 1965, p. 30-39). The Dakota, as mapped in the Hahns Peak and Farwell Mountain quadrangles, may also include beds correlative with the lower sandstone unit, 30-45 feet thick, of the South Platte Formation of the Dakota Group of the eastern Front Range, which is equivalent to the upper member of the Dakota Sandstone (Hail, 1965, p. 32). The age of the Dakota Sandstone there is Early Cretaceous.

MANCOS SHALE

Predominantly marine rocks, mostly light-gray to black shales, conformably overlie the Dakota Sandstone in the map area and have a maximum exposed thickness of 900 feet. The term "Mancos Shale" was employed locally during the University of Wyoming's mapping program in the 1950 's, and the name is retained by the present authors as a practical compromise because of (1) the absence of continuous exposures, which precludes mapping the individual units, and (2) the wide age ranges represented by fossil localities in the area. Much of the southwest quarter of the Hahns Peak quadrangle is mapped as landslides, but the bedrock in that part of the quadrangle is believed to be Mancos Shale. The same is true in the northeastern part of the same quadrangle, where the mapped cover is colluvium, and in the northeastern part of the Farwell Mountain quadrangle, where the mapped cover is till.

A good generalization of the local Mancos lithology is that of Barnwell (1955, p. 73), who stated: "The basal unit, 200 to 300 feet thick, is composed of ferruginous, rectangularly jointed, black shale interbedded with thin beds of bentonite. The middle unit, 53 feet thick, consists of highly arenaceous $* * *$ gray limestone and calcareous sandstone interbedded with bituminous black shale. $* * *$ The upper unit consists of $\mathbf{5 7 6}$ feet of gray to black shale." 
A 40-foot section of the basal unit is exposed in a quarry, about one-half mile north of Columbine, where it lies a few tens of feet above the top of the Dakota Sandstone. This section is characteristic of Barnwell's basal unit of the Mancos.

Hard brittle siliceous shale containing abundant fish scales is exposed along and near an intrusive contact at the south base of Anderson Mountain. It is probably equivalent to the Mowry Shale Member of the Benton Shale of Early Cretaceous age, as described by Hail (1965, p. 34-35) for localities on the east flank of the Park Range.

In the middle unit of the Mancos Shale, exposed in a prospect pit in the saddle between Beryl and Anderson Mountains (USGS Mesozoic loc. D5417), the following fossils were found and identified by W. A. Cobban (written commun., Oct. 31, 1966) : Inoceramus perplexus Whitfield and Scaphites whitfield Cobban. Cobban stated that "These fossils are characteristic of rocks equivalent in age to the uppermost part of the Juana Lopez Member of the Mancos Shale of southern Colorado and New Mexico. In that area the Juana Lopez overlies the Codell Sandstone Member or strata of Codell age and is, in turn, overlain by the Niobrara Formation ***. In northern Colorado the rocks of Juana Lopez and Codell age are usually mapped as the 'Codell Sandstone Member.'" In North Park, the Codell Sandstone Member forms the upper part of the Benton Shale (Hail, 1968, p. 34).

The upper unit of the Mancos Shale in the Hahns Peak region is probably equivalent to the Niobrara Formation, which overlies the Benton Shale with possible disconformity in North Park (Hail, 1968, p. 35). Some upper beds of the upper unit, particularly those which crop out along Beaver Creek, southwest of Hahns Peak, are replete with Inoceramus (Haploscapha) grandis (Conrad, 1875) and Ostrea congesta (Conrad, 1843) of Niobrara age (Barnwell, 1955, p. 73). These fossiliferous beds are within a few tens of feet of the top of the Mancos Shale, as exposed in the mapped area; hence, the Mancos Shale there probably does not contain many beds equivalent to the Pierre Shale.

The age of the Mancos Shale in the Hahns Peak and Farwell Mountain quadrangles is Early and Late Cretaceous.

\section{MIOCENE AND PLIOCENE(?) ROCKS}

BROWNS PARK FORMATION

Coarse conglomerate derived from Precambrian crystalline rocks is widely distributed in both the Hahns Peak and the northwestern part of the Farwell Mountain quadrangles, where thickness of the unit ranges from 0 to 300 feet. The conglomerate truncates the Mancos Shale and older rock units, and it lies at the base of the Browns 
Park Formation of Miocene and Pliocene(?) age. Although rocks of Paleocene, Eocene, and Oligocene age crop out in the Elkhead Mountains, west of the report area, none occur in the Hahns Peak and Farwell Mountain quadrangles. Where the conglomerate is well cemented, it forms hogbacks ( $\mathrm{S} 1 / 2$ sec. 5, T. 10 N., R. 85 W.) and caps hills (W1/2 sec. 33 , T. 10 N., R. 85 W.; sec. 8 , T. 9 N., R. 85 W.). With the exception of the Dakota Sandstone, this conglomerate is the most resistant sedimentary unit in the region.

Irregular slabs of felsic gneiss, amphibolite, and biotite and muscovite schist, as much as 5 feet across, and angular to subangular boulders of quartzite were exposed in core trenches during construction of the Steamboat Lake dam, where about 60 feet of a breccia facies of the Browns Park conglomerate overlies the Mancos Shale, 16 feet below the streambed. There, the matrix ranges from coarse arkosic sand to bentonitic clay, and the stratification is poorly defined locally. In another basal exposure, in a roadcut north of the Royal Flush mine (along the west base of Hahns Peak), the Browns Park conglomerate, 40 feet thick, is made up of subangular to subrounded cobbles of quartzite, gneiss, and granite set in a sandy matrix. It is well stratified, exhibits fluviatile crossbedding, and grades upward into the overlying red sandstone.

Red to yellow sandstone, which locally contains lenses of white fine-grained biotite rhyodacite ash that are a few inches to 2 feet thick, overlies the basal conglomerate, locally with slight disconformity. Bedding textures range from massive to distinctly crossbedded. A clayey cement occurs in the lower part near the basal conglomerate; higher in the section, where sorting of the sand grains is better, the sandstone is relatively uncemented, except in local zones where ground water has deposited iron oxide. Although thickness of Browns Park sandstone in the mapped area ranges from 0 to about 800 feet, the sandstone forms a very discontinuous mantle over the Mesozoic sequence, owing to large-scale stripping of the formation during doming and faulting near Hahns Peak.

Some of the best exposures of the red sandstone are in the SE1/4. sec. 27 , T. 10 N., R. 85 W., and near cor. secs. $21,22,27,28, T .10$ N., R. $85 \mathrm{~W}$. (where artificial channels were dug during the period 1900-1910 to divert Ways Gulch), and in a saddle 0.7 mile westnorthwest of Hahns Peak. The best exposures of yellow sandstone are along Red Creek (middle of sec. 1, T. 9 N., R. 86 W.) and in roadcuts (SE $1 / 4$, sec. 24 , T. 10 N., R. 86 W.). The white ash units are best exposed near the township line between Rs. 85 and $86 \mathrm{~W}$. (about 1,100 ft south of the NW. cor. sec. 7, T. 9 N., R. 85 W.), and just north of the parking area at Steamboat Lake dam, where the ash was probably deposited by direct fall. 
Much work has been done recently on the Browns Park Formation in the Elkhead Mountains (Buffler, 1967) and on the approximately equivalent Troublesome Formation in Middle Park (Izett, 1968). The maximum thickness of the Browns Park in the Elkhead Mountains, 2,200 feet, is attained on the west side of Sand Mountain (Buffler, 1967, p. 38), about 3 miles west of the southwest corner of the Hahns Peak quadrangle. In the eastern part of the Elkhead Mountains, a lower white sandstone facies and an upper brown sandstone facies have been described by Buffler. On Sand Mountain, the upper 800 feet of sandstone is assigned to the brown sandstone facies (Buffler, 1967, p. 47), which is siltier and more loesslike than the fine- to medium-grained white sandstone, although both facies exhibit frosting of grains, crossbedding, and other characteristics of eolian deposition. Much of the sandstone is brown and strongly feldspathic. "In the Sand Mountain [section] $* * *$ appearance of hornblende appears to correspond to the upward change from the white sandstone facies to the brown sandstone facies" (Buffler, 1967, p. 58). "The hornblende in the Browns Park sand is both green and brown and invariably has oxyhornblende associated with it" (Buffler, 1967, p. 68), suggesting a volcanic origin.

The Troublesome Formation has a siltstone facies, which composes most of the unit, and a conglomeratic facies, which is a lateral equivalent of the siltstone facies and "is characterized by orangegray chert-bearing clayey siltstones that contain many thin beds of ash, including several zones of white ash beds that occur near the base and the middle of the formation and zones of gray to olivegray ash in the upper part of the formation" (Izett, 1968, p. 5). Abundant mammalian remains establish the Miocene age for the Troublesome Formation.

On the south side of Shield Mountain, 6 miles northwest of the northwest corner of the Hahns Peak quadrangle, scattered remains of vertebrate fossils occur throughout a 150 -foot stratigraphic interval in the brown sandstone facies of the Browns Park Formation. "Pieces of limb bone from at least three individual camels and a lower jaw of an oreodont were identified, but no material diagnostic of a geologic age. Judging from the size of the humerus bone of one of the camels, the remains there can be assigned an age 'probably no older than middle Miocene," " according to Peter Robinson of the University of Colorado Museum, Boulder (Buffler, 1967, p. 83-84).

\section{PLIOCENE ROCKS}

EPICLASTIC VOLCANIC ROGKS

On a hill 1 mile west-northwest of Hahns Peak, about 400 feet of tuffaceous epiclastic breccia and sandstone overlies the red sandstone of the Browns Park Formation without apparent angular uncon- 
formity, but with possible disconformity. The tuffaceous epiclastic rocks are well lithified and tend to weather in plates about 1-4 inches thick. They consist of poorly sorted angular fragments of dense creamy-white porphyry and dark-gray shale, ranging in size from fine sand to cobbles, that are set in a gray vitreous matrix. The matrix is largely opaline, but it does contain grains of quartz, feldspar, and zircon less than $1 \mathrm{~mm}$ in diameter; no glass is present. Graded bedding and block-sag structure are the outstanding primary features. Reentrants in the larger rock fragments are filled with material which appears to be a hardened slurry of finer grained sediment. The foregoing description is representative, both laterally and vertically, of the entire section of tuffaceous epiclastic rocks.

The large rock fragments, $0.5-10 \mathrm{~cm}$ across, are composed of altered and bleached porphyry that is lithologically similar to the altered intrusive porphyry at Hahns Peak. Both porphyries are buff to white, nonvesicular, and replete with quartz and sanidine, and they are lacking in plagioclase and biotite, which are abundant in the unaltered porphyry of the region. However, pyrite, which is ubiquitous in the altered porphyry at Hahns Peak, is absent in the porphyry clasts of the tuffaceous epiclastic breccia.

"The similarity of porphyry fragments in the breccia on the hill west-northwest of Hahns Peak to the porphyry at Hahns Peak, plus the block-sag structure, suggests that the fragments are airborne products of explosive fragmentation of dense plug rock in a volcano at Hahns Peak" (Segerstrom and Kirby, 1969, p. B21-B22). The rock unit has the same age as the porphyry-early Pliocene.

Nowhere else have these rocks been preserved from erosion. However, volcanic breccias are reported (Buffler, 1967, p. 91-95) from farther west in the Elkhead Mountains, where the composition is basaltic.

\section{INTRUSIVE AND FLOW ROCKS}

Almost all the igneous rocks of Pliocene age in the two quadrangles are intrusive porphyries of intermediate composition, with the exception of the basaltic extrusive rock in the southwest corner of the Hahns Peak quadrangle and the altered porphyry at Hahns Peak (now rhyolitic in composition).

All the porphyries are holocrystalline, but their groundmass is too fine grained to permit reliable modal analyses. Therefore, chemical analyses provided guidance. The nomenclature of Rittmann (1952) is used for the porphyries because it is based on chemical analysis. The felsic-mafic index, below, is also useful in classifying the rock:

$$
\frac{\mathrm{SiO}_{2}+\mathrm{Na}_{2} \mathrm{O}+\mathrm{K}_{2} \mathrm{O}}{\mathrm{FeO}+\mathrm{Fe}_{2} \mathrm{O}_{3}+\mathrm{MgO}+\mathrm{CaO}} \text {. }
$$


The felsic-mafic ratio allows classification of igneous rocks in the following scheme, based on data by Nockolds (1954) on the average chemical composition of igneous rocks :

\begin{tabular}{|c|c|}
\hline Rock type & $\begin{array}{c}\text { Felsic-mafic } \\
\text { index }\end{array}$ \\
\hline Alkali granite (alkali rhyolite) & \\
\hline Granite (rhyolite). & $15-25$ \\
\hline Quartz monzonite (quartz latite). & $10-15$ \\
\hline 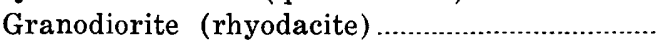 & $7-10$ \\
\hline Quartz diorite (quartz andesite) .................. & $5-7$ \\
\hline 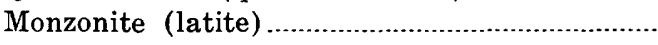 & $3-5$ \\
\hline Diorite (andesite) ........... & $2-3$ \\
\hline Gabbro (basalt) ......... & $1-2$ \\
\hline (........................ & $<\mathbf{1}$ \\
\hline
\end{tabular}

Porphyries that occur in relatively large intrusions in the north half of the Hahns Peak quadrangle are divided into a larger, felsic group and a smaller, mafic group. The samples from localities 182 and 183 represent the felsic group in table 5; those from other localities are not shown in this table.

Phenocrysts in the felsic group make up about 20-40 percent of the rock and are set in a very fine grained holocrystalline matrix. Major minerals are quartz (commonly as rounded phenocrysts), sanidine $\left(\mathrm{Or}_{58-81}\right)$, and plagioclase (oligoclase). Biotite is common, and apatite occurs in most of the porphyries. Black opaque minerals are not common. By X-ray analysis the secondary minerals kaolinite, calcite, and chlorite were found to be present locally. Sanidine phenocrysts in the felsic group are of exceptional size and degree of twinning. The largest ones were found at locality 662, at the west-central edge of the Hahns Peak quadrangle, and at several localities on the south slope of a high hill in sec. 18, T. 10 N., R. 85 $\mathrm{W}$. There, euhedral crystals about $5 \mathrm{~cm}$ long are fairly common. Twinning of the sanidines is commonly Carlsbad, or irregular penetration. A twinned sanidine phenocryst $5 \mathrm{~cm}$ long was determined as $\mathrm{Or}_{67}$ by the $\overline{2} 01 \mathrm{X}$-ray method. The average of seven analyses of sanidine from this group of porphyries was $\mathrm{Or}_{69}$. Zoning is parallel to 001 and 010 , forming a pattern of concentric rectangles, as seen in section normal to these faces.

The second, mafic group of porphyries is represented by samples from localities 671 and 672 (table 5). Both samples contain about 20 percent phenocrysts ; these are set in a very fine grained groundmass. Both contain plagioclase (oligoclase), sanidine, and biotite. The porphyries are fairly free of quartz; they contain a small amount of monoclinic pyroxene. Hornblende, chlorite, sphene, and hematite occur locally. The mafic porphyry from Beryl Mountain also contains pyrite, no doubt owing to its proximity to hydrothermally altered porphyry on Hahns Peak. 
Three small porphyry bodies intrude Precambrian rocks just south of Lester Creek Reservoir, in the Hahns Peak quadrangle. The conical hill immediately south of the reservoir is capped by an outcrop and much rubble of a grayish-brown porphyry. Halfway down the hill to the southwest, similar rock forms a dike about 20 feet wide and 100 feet long. About half a mile southeast of the hill, along the fault between schist and felsic gneiss, there is, roughly, a 300 - by 100 -foot area that is rich in rubble of grayish-brown porphyry. X-ray analysis shows major amounts of plagioclase, quartz, and biotite and minor amounts of sericite, calcite, and potassium feldspar. According to the Rittmann (1952) classification, the analyzed rocks are dark quartz latites (their approximate plutonic equivalent is mafic quartz monzonite).

Dikes 20-50 feet thick are exposed in the northeast quarter of the Hahns Peak quadrangle. These dikes intrude Precambrian felsic gneiss that has been thrust over Mesozoic sedimentary rocks. The dike rocks are light to dark gray and are characterized by numerous euhedral phenocrysts of sanidine, some of which are as much as several centimeters long. Roughly one-third of each rock is made up of phenocrysts set in a very fine grained $(<0.01 \mathrm{~mm})$ groundmass. Rounded and embayed quartz phenocrysts are common. The sanidine is commonly zoned, and some of the large, composite crystals consist of differently oriented individual crystals that appear as a single one in plane-polarized light. Plagioclase (generally oligoclase) occurs as isolated phenocrysts or in intimate association with sanidine. X-ray analysis of the sanidine showed variation from $\mathrm{Or}_{76}$ to $\mathrm{Or}_{58}$. Unaltered biotite is common, and hornblende occurs locally; kaolinite, chlorite, montmorillonite, and calcite are minor secondary constituents; and black opaque minerals, apatite, and sphene are accessory minerals. Analyses of two samples (Nos. 5, 6) of these dike rocks (locs. 221, 245) are given in table 5.

The only Tertiary igneous rocks exposed in the Farwell Mountain quadrangle are two narrow dikes. One dike, in the southwest corner of the quadrangle, is $10 \mathrm{ft}$ wide and at least 750 feet long. This dike (represented by sample 7 from loc. 13B, table 5), is composed of dark, very fine grained porphyry. In thin section the grain size of the groundmass is seen to be about $0.02 \mathrm{~mm}$. Phenocrysts are sparse and small (about $1 \mathrm{~mm}$ ). Alteration is so intense that sericite, chlorite, and calcite obscure the phenocrysts and groundmass. Several percent of very fine grained opaque minerals are evenly disseminated throughout the rock. X-ray analysis shows that the essential minerals are plagioclase and quartz. Secondary minerals are biotite, sericite, chlorite, potassium feldspar, and calcite. Assuming that no change in chemistry occurred during alteration, the rock is believed to be a rhyodacite porphyry. 
The other exposed dike in the Farwell Mountain quadrangle is in the southeast corner (sample 8, loc. 132, table 5). The outcrop is elongate $(\approx 200 \mathrm{ft})$ and thin $(1-2 \mathrm{ft})$, and it dips about $85^{\circ} \mathrm{SW}$., discordant to the foliation in the surrounding felsic gneiss complex. Sample 8 (loc. 132) is dense black very fine grained porphyry. Phenocrysts of plagioclase are fairly abundant, and some have a maximum dimension of several millimeters. X-ray analysis of sample 8 shows major amounts of plagioclase, quartz, and biotite and minor amounts of sericite and calcite. The rock is a trachyandesite porphyry (of which the plutonic equivalent is monzodiorite) ; hence, it is somewhat more mafic than sample 7 from locality $13 \mathrm{~B}$, as also indicated by its lower felsic-mafic index and its higher density.

The porphyry at Hahns Peak and at a few other places has been hydrothermally altered. Emmons (Hague and Emmons, 1877, p. 173-174) described the porphyry as follows:

The trachyte which forms the main mass of Hantz Peak is a mauve-colored rock, which separates easily into sherd-like laminae. It shows occasional grains of rounded quartz, with white, decomposed feldspars, and considerable amounts of black mica and hornblende, in a grayish felsitic groundmass, and mineralogically belongs rather to the basic group of trachytes of Camel Peak. Singularly enough, however, the very summit of the peak is made up of a white porous rock, which has all the characteristics of a rhyolite, consisting mainly of grains of free quartz and crystals of sanidine-feldspar in a white, porous, felsitic groundmass. In it the microscope detects no plagioclase, hornblende, or biotite. Some of the quartz crystals of this rock are seen to contain very perfect dihexahedral fluid-inclusions containing a moving bubble.

The mauve-colored rock described by Emmons would correspond to the sample from locality 1S (table 5), which is mauve colored and is about 15 percent phenocrysts of sanidine, albite, and a small amount of biotite. Sericite and a trace of apatite are also seen in thin section. The groundmass is very fine grained $(<0.02 \mathrm{~mm})$ and must contain considerable quartz, in addition to feldspar, inasmuch as X-ray analysis shows the major constituents to be quartz, plagioclase, and potash feldspar. Sericite, biotite, and kaolinite are minor constituents.

The white porous rock described by Emmons is light cream in color and contains about 30 percent phenocrysts of sanidine, albite, quartz, and sericite. This rock is more intensely altered and more fragmented or brecciated than that from locality 1S.

The mauve-colored porphyry at Hahns Peak (loc. 1S, table 5) has the felsic-mafic index (24.1) of a granite (rhyolite), and the cream-colored porphyry at Hahns Peak yields the unusually high index of 87.4 (alkali granite or alkali rhyolite). Both rock types, however, represent hydrothermal alteration of an originally intermediate rock. The cream-colored rock, commensurate with its appearance of hydrothermal alteration, contains markedly less iron, 
TABLE 5. - Chemical and spectrographic analyses of Tertiary igneous rocks in the Hahns Peak and Farwell Mountain quadrangles [Rapid-rock chemical analyses: analysts for all samples except 9 and 10, P. L. D. Elmore, Gillison Chloe, James Kelsey, S. D. Botts, H. Smith, Lowell Artis, and John Glenn. Standard rock analyses for sample 9 by C. L. Parker and for sample 10 by E. E. Engleman. The following elements were looked for by semiquantitative spectrographic analysis but were not detected (detection limit in parentheses): $\mathrm{Ag}(0.1), \mathrm{As}(100), \mathrm{Au}(10), \mathrm{B}(30), \mathrm{Bi}(3), \mathrm{Cd}(10), \mathrm{Ge}$ (3), Hf (20), In (1), Li (30), Pd (1), Pt (3), Re (30), Sb (100), Sn (3), Ta (300), Te (300), Th (100), Ti (10), U (300), W (30), Zn (100). Spectrographic analyses for samples $1,2,5$, and 6 by J. L. Harris; for samples 7 and 8 by W. B. Crandell; for sample 9 by G. W. Sears, Jr.; and for sample 10 by Harriet Neiman. See table 1, footnote 1, for explanation of powder density; see table 1, footnote 2, and text on p. 34-35 for explanation of felsic-mafic index. Leaders (....) indicate not determined]

\begin{tabular}{|c|c|c|c|c|c|c|c|c|c|c|c|c|}
\hline $\begin{array}{l}\text { Sample No.............. } \\
\text { Lab. No. } \\
\text { Field loc. No... } \\
\text { Rock name and No........ } \\
\text { (from Rittman) }\end{array}$ & $\begin{array}{c}1 \\
\text { W170247 } \\
182 \\
\text { Rhyolite } \\
\text { (A3) }\end{array}$ & $\begin{array}{c}2 \\
\text { W170248 } \\
183 \\
\text { Quartz } \\
\text { latite } \\
\text { (A4) }\end{array}$ & \begin{tabular}{c}
3 \\
\hdashline 671 \\
Quartz \\
latite \\
(A4)
\end{tabular} & \begin{tabular}{c}
4 \\
\hdashline 672 \\
Quartz \\
latite \\
(A4)
\end{tabular} & $\begin{array}{c}5 \\
\text { W170250 } \\
221 \\
\text { Quartz } \\
\text { latite } \\
\text { (A4) }\end{array}$ & $\begin{array}{c}6 \\
\text { W } 170251 \\
245 \\
\text { Quartz } \\
\text { latite } \\
\text { (A4) }\end{array}$ & $\begin{array}{c}7 \\
\text { W171429 } \\
\text { 13B } \\
\text { Rhyodacite } \\
\text { (A5) }\end{array}$ & $\begin{array}{c}8 \\
\text { W171437 } \\
132 \\
\text { Trachy- } \\
\text { andesite } \\
\text { (B5) }\end{array}$ & $\begin{array}{c}9 \\
\text { D101773 } \\
\text { 1S } \\
\text { Rhyolite } \\
\text { (A3) }\end{array}$ & $\begin{array}{c}10 \\
\text { D101737 } \\
1 \mathrm{C} \\
\text { Dark } \\
\text { alkali } \\
\text { trachyte } \\
\text { (B2) }\end{array}$ & $\begin{array}{c}11 \\
660 \\
\text { Andesine } \\
\text { trachy- } \\
\text { basalt } \\
\text { (B5) }\end{array}$ & $\begin{array}{c}12 \\
661 \\
\text { Olivine- } \\
\text { andesine } \\
\text { trachy- } \\
\text { basalt } \\
\text { (BC5) }\end{array}$ \\
\hline \multicolumn{13}{|c|}{ Rapid-rock chemical analyses for major constituents (weight percent) } \\
\hline $\begin{array}{l}\mathrm{SiO}_{2} \ldots \\
\mathrm{Al}_{2} \mathrm{O}_{3} \\
\mathrm{Fe}_{2} \mathrm{O}_{3} \\
\mathrm{FeO} \\
\mathrm{MgO}\end{array}$ & $\begin{array}{c}69.1 \\
15.4 \\
1.7 \\
.56 \\
.80\end{array}$ & $\begin{aligned} 72.4 \\
14.8 \\
.91 \\
.72 \\
.38\end{aligned}$ & $\begin{array}{c}63.3 \\
15.6 \\
3.8 \\
.92 \\
2.6\end{array}$ & $\begin{array}{c}62.3 \\
15.8 \\
3.8 \\
.92 \\
2.7\end{array}$ & $\begin{array}{c}68.7 \\
15.0 \\
1.8 \\
.76 \\
1.1\end{array}$ & $\begin{array}{c}67.9 \\
15.0 \\
1.8 \\
.84 \\
.65\end{array}$ & $\begin{array}{r}59.1 \\
16.0 \\
6.5 \\
1.2 \\
2.5\end{array}$ & $\begin{array}{r}55.7 \\
15.2 \\
4.9 \\
3.9 \\
2.5\end{array}$ & $\begin{array}{r}69.19 \\
15.57 \\
2.43 \\
.18 \\
.32\end{array}$ & $\begin{array}{r}61.64 \\
13.96 \\
2.15 \\
3.06 \\
2.86\end{array}$ & $\begin{array}{r}54.7 \\
14.3 \\
4.2 \\
3.3 \\
6.7\end{array}$ & $\begin{array}{r}46.4 \\
11.6 \\
3.2 \\
4.7 \\
8.5\end{array}$ \\
\hline $\begin{array}{l}\mathrm{CaO} \\
\mathrm{Na}_{2} \mathrm{O} \\
\mathrm{K}_{2} \mathrm{O} \\
\mathrm{H}_{2} \mathrm{O}- \\
\mathrm{H}_{2} \mathrm{O}+\end{array}$ & $\begin{array}{l}1.1 \\
2.4 \\
6.0 \\
1.5 \\
.90\end{array}$ & $\begin{array}{l}1.1 \\
3.7 \\
4.0 \\
.39 \\
.91\end{array}$ & $\begin{array}{l}4.0 \\
4.1 \\
3.2 \\
.43 \\
.77\end{array}$ & $\begin{array}{l}4.3 \\
4.1 \\
3.3 \\
.39 \\
.91\end{array}$ & $\begin{array}{l}1.6 \\
3.6 \\
3.7 \\
1.6 \\
1.2\end{array}$ & $\begin{array}{l}2.9 \\
2.1 \\
4.2 \\
.53 \\
1.9\end{array}$ & $\begin{array}{l}3.9 \\
3.2 \\
3.3 \\
.26 \\
1.1\end{array}$ & $\begin{array}{l}4.7 \\
4.2 \\
2.6 \\
.72 \\
1.1\end{array}$ & $\begin{array}{l}.32 \\
2.90 \\
6.24 \\
.37 \\
1.34\end{array}$ & $\begin{array}{r}2.65 \\
4.10 \\
4.88 \\
.31 \\
.65\end{array}$ & $\begin{array}{l}7.4 \\
3.7 \\
2.6 \\
.41 \\
.89\end{array}$ & $\begin{array}{l}8.0 \\
2.7 \\
2.1 \\
.61 \\
1.3\end{array}$ \\
\hline $\begin{array}{l}\mathrm{TiO}_{2} \\
\mathrm{P}_{2} \mathrm{O}_{5} \\
\mathrm{MnO} \\
\mathrm{CO}_{2} \\
\mathrm{Cl}\end{array}$ & $\begin{array}{r}.33 \\
.17 \\
.02 \\
<.05 \\
. . .\end{array}$ & $\begin{array}{r}.19 \\
.10 \\
.03 \\
<.05 \\
-\ldots . . .\end{array}$ & $\begin{array}{r}.81 \\
.38 \\
.11 \\
<.05 \\
. . . .\end{array}$ & $\begin{array}{r}.86 \\
.36 \\
.10 \\
<.05 \\
. . . .\end{array}$ & $\begin{array}{r}.45 \\
.28 \\
.03 \\
<.05 \\
. . . . .\end{array}$ & $\begin{array}{l}.39 \\
.23 \\
.06 \\
.93 \\
. . . .\end{array}$ & $\begin{array}{l}1.5 \\
.71 \\
.08 \\
.52 \\
\ldots \ldots . .\end{array}$ & $\begin{array}{l}1.7 \\
.83 \\
.23 \\
2.4 \\
. . . . .\end{array}$ & $\begin{array}{l}.46 \\
.21 \\
.02 \\
.00 \\
.00\end{array}$ & $\begin{array}{r}.92 \\
.63 \\
.14 \\
1.21 \\
.00\end{array}$ & $\begin{array}{r}1.2 \\
.50 \\
.14 \\
<.05 \\
. . . .\end{array}$ & $\begin{array}{l}1.1 \\
.57 \\
.16 \\
8.5 \\
. . . . .\end{array}$ \\
\hline $\begin{array}{l}\text { F } \\
\text { BaO }\end{array}$ & (n...... & …... & (n..... & $\begin{array}{ll}\ldots \ldots \ldots . \\
\cdots \cdots \cdots . . \\
\cdots \cdots \cdots .\end{array}$ & (n..... & (n..... & (n...... & (…... & $\begin{array}{l}.11 \\
.18 \\
.02\end{array}$ & $\begin{array}{l}.21 \\
.37 \\
.05\end{array}$ & (n..... & (n)... \\
\hline $\begin{array}{l}\text { Subtotal } \\
\text { Less } O \text { for } F \\
\text { and } S\end{array}$ & 100 & 100 & 100 & 100 & $\begin{array}{r}100 \\
\ldots \ldots . . \\
\end{array}$ & $\begin{array}{l}99 \\
\ldots \ldots \ldots \\
\end{array}$ & 100 & 100 & $\begin{array}{r}99.86 \\
.06 \\
\end{array}$ & $\begin{array}{r}99.79 \\
.11 \\
\end{array}$ & 100 & $\begin{array}{l}99 \\
\ldots \ldots . . \\
\end{array}$ \\
\hline Total.................... & 100 & 100 & 100 & 100 & 100 & 99 & 100 & 100 & 99.80 & 99.68 & 100 & 99 \\
\hline $\begin{array}{l}\text { Powder density................. } \\
\text { Felsic-mafic index............ }\end{array}$ & $\begin{array}{l}2.617 \\
18.6\end{array}$ & $\begin{array}{l}2.649 \\
25.8 \\
\end{array}$ & $\begin{array}{l}2.701 \\
6.23 \\
\end{array}$ & $\begin{array}{l}2.711 \\
5.94\end{array}$ & $\begin{array}{c}2.651 \\
14.5\end{array}$ & $\begin{array}{r}2.671 \\
12.0\end{array}$ & $\begin{array}{l}2.795 \\
4.65 \\
\end{array}$ & $\begin{array}{l}2.835 \\
3.80 \\
\end{array}$ & 24.1 & $\begin{array}{l}2.691 \\
6.58 \\
\end{array}$ & $\begin{array}{l}2.862 \\
2.67 \\
\end{array}$ & $\begin{array}{l}2.775 \\
2.10 \\
\end{array}$ \\
\hline
\end{tabular}


Semiquantitative spectrographic analyses for minor constituents (parts per million)

\begin{tabular}{|c|c|c|c|c|c|c|c|c|c|c|c|c|}
\hline 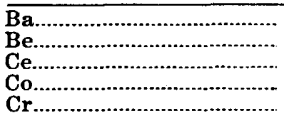 & $\begin{array}{r}1,500 \\
3 \\
100 \\
<1 \\
20\end{array}$ & $\begin{array}{r}1,500 \\
3 \\
<100 \\
<1 \\
3\end{array}$ & $\begin{array}{ll}\ldots \ldots . . \\
\cdots \cdots \cdots . . \\
\cdots \cdots \cdots . . \\
\cdots \cdots \cdots . .\end{array}$ & 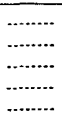 & $\begin{array}{r}1,500 \\
3 \\
200 \\
7 \\
30\end{array}$ & $\begin{array}{r}1,500 \\
3 \\
200 \\
10 \\
30\end{array}$ & $\begin{array}{r}3,000 \\
2 \\
500 \\
20 \\
70\end{array}$ & $\begin{array}{r}2,000 \\
2 \\
500 \\
15 \\
70\end{array}$ & $\begin{array}{r}3,000 \\
2 \\
<150 \\
3 \\
50\end{array}$ & $\begin{array}{r}5,000 \\
3 \\
150 \\
20 \\
150\end{array}$ & $\begin{array}{ll}\ldots \ldots . . \\
\cdots \cdots \cdots . . \\
\cdots \cdots \cdots . . \\
\cdots \cdots \cdots . .\end{array}$ & 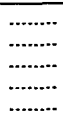 \\
\hline $\begin{array}{l}\text { Cu } \\
\text { Ga } \\
\text { La } \\
\text { Mo } \\
\text { Nb. }\end{array}$ & $\begin{array}{r}7 \\
15 \\
70 \\
<3 \\
10\end{array}$ & $\begin{array}{r}5 \\
15 \\
<30 \\
3 \\
10\end{array}$ & …... & $\begin{array}{ll}\cdots \ldots . . . \\
\cdots \cdots \cdots . . \\
\cdots \cdots \cdots . . \\
\cdots \cdots . . .\end{array}$ & $\begin{array}{r}30 \\
15 \\
70 \\
<3 \\
10\end{array}$ & $\begin{array}{r}10 \\
15 \\
70 \\
<3 \\
10\end{array}$ & $\begin{array}{r}30 \\
20 \\
300 \\
5 \\
15\end{array}$ & $\begin{array}{r}15 \\
20 \\
300 \\
5 \\
15\end{array}$ & $\begin{array}{r}\mathbf{1 . 5} \\
\mathbf{3 0} \\
\mathbf{5 0} \\
<\mathbf{3} \\
<10\end{array}$ & $\begin{array}{r}50 \\
30 \\
100 \\
3 \\
10\end{array}$ & $\begin{array}{ll}\ldots \ldots . . . \\
\cdots \cdots \cdots . . \\
\cdots \cdots \cdots . . \\
\cdots \cdots \cdots . . .\end{array}$ & $\begin{array}{ll}\ldots \ldots . . \\
\cdots \cdots \cdots . . \\
\cdots \cdots . . . \\
\cdots \cdots . . .\end{array}$ \\
\hline 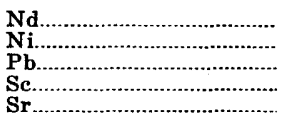 & $\begin{array}{r}<100 \\
<30 \\
50 \\
5 \\
300\end{array}$ & $\begin{array}{r}<\mathbf{1 0 0} \\
<\mathbf{3 0} \\
\mathbf{5 0} \\
\mathbf{1} \\
\mathbf{5 0 0}\end{array}$ & …... & $\begin{array}{ll}-\ldots \ldots . . \\
\cdots \cdots \cdots . . \\
\cdots \cdots \cdots . . \\
\cdots \cdots . . .\end{array}$ & $\begin{array}{r}<100 \\
30 \\
50 \\
5 \\
700\end{array}$ & $\begin{array}{r}<100 \\
30 \\
50 \\
5 \\
300\end{array}$ & $\begin{array}{r}300 \\
30 \\
20 \\
15 \\
1,500\end{array}$ & $\begin{array}{r}300 \\
30 \\
10 \\
25 \\
1,500\end{array}$ & $\begin{array}{r}<70 \\
15 \\
10 \\
7 \\
200\end{array}$ & $\begin{array}{r}100 \\
150 \\
70 \\
10 \\
1,000\end{array}$ & (…... & 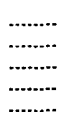 \\
\hline $\begin{array}{l}\text { V. } \\
\text { Y } \\
\text { Yb. } \\
\mathbf{Z b} \\
\mathbf{A g}\end{array}$ & $\begin{array}{r}30 \\
20 \\
2 \\
100 \\
2\end{array}$ & $\begin{array}{l}15 \\
<3 \\
100 \\
<.1\end{array}$ & 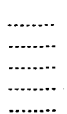 & $\begin{array}{ll}\cdots \cdots . . . \\
\cdots \cdots . . . \\
\cdots \cdots . . . \\
\cdots \cdots . . .\end{array}$ & $\begin{array}{r}30 \\
20 \\
2 \\
200 \\
<.1\end{array}$ & $\begin{array}{r}30 \\
20 \\
2 \\
200 \\
<.1\end{array}$ & $\begin{array}{r}150 \\
30 \\
3 \\
300 \\
\quad<.1\end{array}$ & $\begin{array}{r}100 \\
30 \\
3 \\
700 \\
<.1\end{array}$ & $\begin{array}{c}70 \\
15 \\
1.5 \\
150 \\
<.1\end{array}$ & $\begin{array}{c}150 \\
15 \\
1.5 \\
200 \\
<.1\end{array}$ & 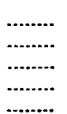 & 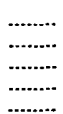 \\
\hline
\end{tabular}

SAMPLE LOCALITIES

1. N1/2 sec. 23, T. 10 N., R. 85 W.

2. NW $1 / 4$ sec. $23, T$ T. 10 N., R. 85 W.

4. SE $1 / 4$ sec. 20 , T. 10 N., R. 85 W.

5. $W^{1 / 2}$ sec. $11, T .10$ N., R. 85 W.
6. SW $1 / 4$ sec. 11, T. 10 N., R. 85 W.
7. SW1/4 sec. 7, T. 9 N., R. $84 \mathrm{~W}$.

8. NW1/4 sec. 2, T. 9 N., R. 84 W.

10. Near center of sec. 9, T. 10 N., R. 85 W.

11. SW cor. sec. 1, T. 9 N., R. 86 W.
SW cor. sec. 25, T. 10 N., R. 86 W. 
magnesium, calcium, and sodium, and more potassium than does the sample from locality 1S.

Locally, at Hahns Peak, small dikes of dark-gray-brown porphyry have intruded the porphyry. One such dike, from drill core, is represented by sample 10 (loc. $1 \mathrm{C}$, table 5). About 20 percent of the dike rock consists of phenocrysts set in a very fine grained felty groundmass of trachytic texture. Phenocrysts are quartz, oligoclase, sanidine $\left(O r_{95}\right)$, biotite, hornblende, and a few pale-green pyroxene. Optical properties of the pyroxene, determined by Irving Witkind of the U.S. Geological Survey, are $\alpha=1.676, \beta=1.687, \gamma=1.705$; $2 V_{z}=57^{\circ}, Z \lambda_{c}=40^{\circ}$; these correspond to the optical properties of augite (salite). Calcite is a secondary constituent, and black opaque minerals, apatite, and sphene are accessory minerals. X-ray analysis of the rock shows that oligoclase, potassium feldspar, and quartz are major minerals, and that biotite and hornblende are minor minerals.

Although the Rittmann method classes this rock as dark alkali trachyte, the abundant quartz and low felsic-mafic index (6.58) would indicate that the porphyry is equivalent to the quartz diorite (quartz andesite) of Nockolds (1954).

Two rock types in the southwest corner of the mapped area are represented by samples 11 and 12 (table 5, locs. 660 and 661, respectively) : sample 11 is an amygdular very fine grained slightly porphyritic flow rock; sample 12 is a denser slightly porphyritic basaltic-looking dike rock. Both contain olivine and monoclinic pyroxene. Groundmass in both rocks is a felty mass of feldspar, which X-ray analysis indicates to be a soda-rich sanidine or anorthoclase. Plagioclase content-if present-is small. The felsicmafic index of the flow rock (loc. 660), 2.67, fits Nockolds' diorite (andesite), whereas the index of the dike rock (loc. 661), 2.10, approaches that of Nockolds' gabbro (basalt) .

\section{AGE OF EXTRUSIVE AND INTRUSIVE ROCKS}

Potassium-argon determinations on sanidine from the porphyry at Hahns Peak, as well as on sanidine and biotite from a dike that cuts the porphyry, show a range in age from 10 to 11.5 m.y. The oldest age is that of the dike (11.5 m.y. on sanidine), which suggests that leakage of argon may account for the younger age of the intruded porphyry ( 10.0 m.y. on sanidine). If this is so, a reasonable age estimate for the porphyry may be about $12 \mathrm{~m} . \mathrm{y}$. (MiocenePliocene boundary). Data concerning these ages and on an age for felsite porphyry from East Gibraltar Peak (15 miles west of Hahns Peak, in the Elkhead Mountains) are given in table 6. No age determinations were made on the basaltic flows and dikes of the area. 
TABLE 6. - Potassium-argon ages of sanidine and biotite that were separated from upper Tertiary igneous rocks

[Field localities are shown on pl. 1, except for 2A. Analysts: R. F. Marvin, H. H. Mehnert, and Violet Merritt]

\begin{tabular}{|c|c|c|c|c|c|c|c|c|}
\hline \multicolumn{2}{|c|}{ Decay constants: } & \multicolumn{2}{|c|}{$\begin{aligned} \mathrm{K}^{40} \lambda_{\mathrm{t}} & =0.585 \times 10^{-10} \text { per yr; } \\
\lambda_{B} & =4.72 \times 10^{-10} \text { per } \mathrm{yr} .\end{aligned}$} & \multicolumn{4}{|c|}{ A tomic abundance: $K^{40}=1.19 \times 10^{-4}$. } & \multirow[b]{2}{*}{$\underset{(\mathrm{m} \cdot \mathrm{y} .)}{\text { Age }}$} \\
\hline Mineral & $\begin{array}{l}\text { Field } \\
\text { loc. } \\
\text { No. }\end{array}$ & $\begin{array}{l}\text { Rock } \\
\text { type }\end{array}$ & Location & $\begin{array}{l}\mathrm{K}_{2} \mathrm{O} \\
\text { (per- } \\
\text { cent) }\end{array}$ & $\begin{array}{l}\text { Arto } \\
\left(10^{-10}\right. \\
\text { moles/ } \\
\text { gram })\end{array}$ & $\begin{array}{c}\text { Radio- } \\
\text { genic } \\
\text { Ar }{ }^{* 0} \\
\text { (percent) }\end{array}$ & $\operatorname{Ar}^{40} / \mathrm{K}^{40}$ & \\
\hline \multirow[t]{2}{*}{ Sanidine... } & $1 \mathrm{~A}$ & $\begin{array}{l}\text { Porphyry at } \\
\text { Hahns Peak. }\end{array}$ & $\begin{array}{l}\text { Sec. } 9 \\
\text { T. } 10 \mathrm{~N} . \\
\text { R. } 85 \mathrm{~W} \text {. }\end{array}$ & 10.94 & 1.617 & 94 & 0.000585 & $10.0 \pm 0.3$ \\
\hline & $7 \mathrm{~K}$ & Dacite porphyry... & $\begin{array}{l}\text { Sec. } 35, \\
\text { T. } 11 \mathrm{~N} . \\
\text { R. } 85 \mathrm{~W} .\end{array}$ & 10.76 & 1.641 & 90 & .000604 & $10.3 \pm 0.3$ \\
\hline Biotite........ & $1 \mathrm{C}$ & $\begin{array}{l}\text { Quartz andesite } \\
\text { dike intruding } \\
\text { porphyry at } \\
\text { Hahns Peak, in } \\
\text { DDH-6. }\end{array}$ & $\begin{array}{l}\text { Sec. } 9 \\
\text { T. } 10 \mathrm{~N} . \\
\text { R. } 85 \mathrm{~W} .\end{array}$ & 8.31 & 1.317 & 69 & .000627 & $10.7 \pm 0.4$ \\
\hline \multirow[t]{2}{*}{ Sanidine... } & $1 \mathrm{C}$ & ...do...................... & $\begin{array}{l}\text { Sec. } 9 \text {, } \\
\text { T. } 10 \mathrm{~N} . \\
\text { R. } 85 \mathrm{~W} .\end{array}$ & 6.49 & 1.102 & 81 & .000672 & $11.5 \pm 0.4$ \\
\hline & $2 A$ & $\begin{array}{l}\text { Felsite } \\
\text { porphyry, East } \\
\text { Gibraltar Peak, } \\
\text { Colo. }\end{array}$ & $\begin{array}{l}\text { Sec. } 24, \\
\text { T.11 N., } \\
\text { R. } 88 \text { W. }\end{array}$ & 10.59 & 1.412 & 93 & .000528 & $9.0 \pm 0.3$ \\
\hline
\end{tabular}

McDowell (1966) reported a potassium-argon age of $9.5 \pm 0.3$ m.y. for biotite separated from porphyry at Hahns Peak float found near Columbine.

Buffler (1967). reported the following potassium-argon ages of rocks from the Elkhead Mountains:

1. $11.1 \pm 0.5 \mathrm{~m} . \mathrm{y}$. for biotite from a lamprophyre dike that intrudes a diatreme at Brush Mountain, Colo. (sec. 34, T. 11 N., R. 88 W.) ;

2. 7.6 \pm 0.4 m.y: for biotite from a latite porphyry intrusion that constitutes City Mountain, Colo. (sec. 26, T. 11 N., R. 86 W.) ;

3. $9.5 \pm 0.5$ m.y. for biotite from a vesicular basalt flow north of

Bible Back Mountain, Colo. (sec. 23, T. 12 N., R. 89 W.) ; and 4. $10.7 \pm 0.5$ m.y. for olivine basalt from the top of Battle Mountain,

Wyo. (sec. 10, T. 12 N., R. 88 W.).

\section{CONTACT METAMORPHIC ROCKS}

At two localities in the Hahns Peak quadrangle, hornfels is exposed near porphyry dikes, in aureole zones as much as several tens of feet wide around the intrusive contact. The localities are 2,100 feet north and 350 feet west of the SE. cor. sec. 9, T. 10 N., R. 85 W., and 1,850 feet north of the common corner of secs. 10,11,14, and 15 in the same township. The areal extent of these exposures is not sufficient to permit their portrayal on the map. Before metamorphism, the rock was claystone of the Morrison Formation or shale of the Mancos Shale.

The rock is flinty-hard, dark gray, and very fine grained. Rapidrock analysis of the sample from locality 674 , the second locality, shows an exceptionally high silica content (table 7). 
TABLE 7. - Rapid-rock chemical analysis of a contact metamorphic rock (field loc. 674) in the Hahns Peak quadrangle

[Analyzed by P. L. D. Elmore and others]

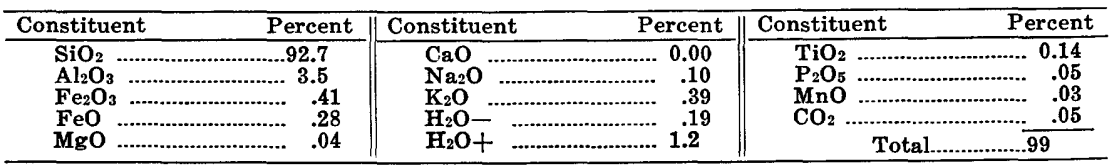

It is noteworthy that all the porphyry intrusions in the area have caused so little contact metamorphism of the country rock. Fresh fossiliferous shale is seen adjacent to intrusive porphyry contacts in the saddle between Beryl and Anderson Mountains, in the eastern part of sec. 16, T. 10 N., R. $85 \mathrm{~W}$., and at the southwest base of Anderson Mountain, in the southern part of the same section. Even in small roof pendants on Hahns Peak and Twin Mountain, and in large xenoliths enclosed by the porphyry, there is little or no contact effect apparent in the Mancos Shale.

\section{QUATERNARY DEPOSITS}

About 35 percent of the mapped area is so thickly covered with surficial deposits that the bedrock units cannot be shown. The surficial deposits, ranging in age from Pleistocene to Holocene, are divided into nine units-five of them glacial, or possibly proglacial, and four of them postglacial. The glacial deposits are virtually restricted to the Farwell Mountain quadrangle; Hahns Peak and the mountains west and south of the peak were never glaciated. (See Atwood, 1937, fig. 9.) Most of the mapped till deposits overlie Mesozoic rocks, which tend to form topographic lows because they are less resistant to erosion than the older crystalline rocks.

\section{PRE-BULL LAKE TILL}

Most of the southwest quarter of the Farwell Mountain quadrangle and a small area in the southeastern part of the Hahns Peak quadrangle are covered by hummocky till, which-because of its partly decomposed boulder content and its topographic position-is believed to be the oldest surficial deposit in the two quadrangles. The freshest cobbles and boulders in the deposit are of silicified Dakota Sandstone; the others are derived from Precambrian bedrock. Clayey parts of the matrix may have been derived from the Morrison Formation. Other Jurassic and Triassic rocks probably contributed sand to the till.

Most of the till was deposited by the Hinman Glacier (Atwood, 1937, fig. 9), which headed between the crest of Farwell Mountain and the Continental Divide and moved south and southwest across the Farwell Mountain quadrangle via Hinman Creek, Diamond Park, Scott Run, and the present Hinman Lake area. Deposits of this early glacier were scraped away and (or) covered by later gla- 
cial action in the upper reaches, but they still cover the lowland between Hinman and Coulton Creeks and part of the Elk River valley, in the adjacent Clark quadrangle, to the south.

BULL LAKE(?) TILL

A large area along the east edge of the mapped area is covered by a till sheet that is younger and better preserved than the pre-Bull Lake till. Glaciers from the Park Range, which deposited the till sheet as they moved across the upper reaches of terrain previously covered by the Hinman Glacier, subsequently formed lateral moraines on the west side of Trail Creek, at an altitude of 9,600-8,400 feet above sea level, and high above the North Fork Elk River at an altitude of 9,400-8,800 feet. A small tongue of one of the Park Range glaciers descended Scott Run, scouring out the earlier till and redepositing it and other material in a terminal moraine, 8,250 feet above sea level, at the junction of Scott Run and Hinman Creek. A larger tongue debouched precipitously westward onto Hinman Park, 7,800-7,650 feet above sea level. Another glacial tongue, terminating at Hinman Park, was fed by glaciers from the Middle and South Forks Elk River that deposited a medial moraine 500 feet thick between the two rivers. The terminal moraine or moraines at Hinman Park are, thus, an accumulation of till from several sources.

Precambrian boulders in, and on top of, this younger till tend to be less decomposed than those of the oldest till, and they are much larger. The largest erratics are of pegmatite; one on the west side of Trail Creek, 1.7 miles northwest of the junction of the creek with the North Fork Elk River, is 35 feet across and 15 feet high.

This till sheet, the second youngest in the area, is correlated with the Bull Lake Glaciation in the Wind River Range of Wyoming. As determined by a criterion which has been enployed in Rocky Mountain National Park, "the deposits are the oldest and most extensive of those having well-preserved morainal topography" (Richmond, 1960, p. 1373).

\section{PINEDALE(?) TILL}

The youngest till occurs in two areas near the east edge of the Farwell Mountain quadrangle: Diamond Park and the Seedhouse area. A late glacier from the steep upper gorge of the North Fork Elk River debouched onto the fairly flat valley at Diamond Park and deposited a terminal moraine at about 8,600 feet. Other late glaciers from the gorges of the Middle and South Forks Elk River overrode the eastern part of the Bull Lake medial moraine, which had been deposited between the two rivers, and formed a terminal moraine southeast and south of the Seedhouse area, at 8,150-8,050 feet above sea level.

Enormous, fresh erratics occur in the Pinedale(?), as they do 
in the Bull Lake(?) Till. One, of pegmatite, shown on the map (pl. 1) near the Seedhouse area, is used as a natural backdrop for the Forest Service campground shows during the summer tourist season. Topography of the Pinedale(?) moraines is bold and relatively undissected; it is similar to that of the Pinedale Till in its type locality in the Wind River Range, Wyo. (Blackwelder, 1915). Although some Neoglaciation features in the high country east of the Farwell Mountain quadrangle may be younger, the Pinedale Glaciation should be considered the youngest in the area.

\section{TERRACE GRAVELS}

An older, or higher, gravel and a younger, or lower, gravel crop out along the valley of the North Fork Elk River. Both gravels are fairly well sorted and well bedded and are either stream deposits or glacial outwash deposits.

\section{LANDSLIDE DEPOSITS}

Landslide deposits cover much of the west-central part of the Farwell Mountain quadrangle and the south-central part of the Hahns Peak quadrangle. Those in the Farwell Mountain quadrangle consist of subangular to angular clasts of Precambrian gneiss set in a sandy to silty matrix. Their morphology-hummocky, and lying below amphitheatral headwalls-distinguishes them from ordinary colluvium. The landslide deposits in the south-central part of the Hahns Peak quadrangle have well-rounded to subrounded boulders, cobbles, and pebbles of Precambrian gneiss in a silty to clayey matrix that contains abundant chips of Mancos Shale.

The sliding of the angular material can be attributed to the exceptionally steep relief-1,500 feet per mile-on the south side of Farwell Mountain. The slides of the more rounded clasts occurred because shale bedrock underlies more competent material-basal conglomerate of Browns Park Formation-and because, when it is soaked with water, the shale oozes like toothpaste, causing the overlying scarps to collapse, both downward and outward.

A third type of landslide deposit consists of large angular blocks of sandstone and conglomerate of the Dakota set in a very small amount of matrix at or near the surface. The occurrences are small, and some of them form surfaces of such low gradient $\left(5^{\circ}-10^{\circ}\right)$ that it is difficult to imagine how the blocks could have moved to their present positions. A low-gradient deposit about half a mile southwest of the mouth of Hole-in-Wall Canyon-just south of the center of the Farwell Mountain quadrangle, was termed a "block field" by McConnell (1960, p. 56-57), who described it as a periglacial feature that was formed during Pleistocene glaciation. The 
deposits that have steeper surfaces are probably better classified as monolithologic landslides than as periglacial features.

\section{COLLUVIUM}

Colluvium, or slope-wash deposits, occur on most of the hillslopes of the area, but they are shown on the map (pl. 1) only where they are thick $(>5 \mathrm{ft})$ and extensive $(>1,000 \mathrm{ft}$ long). The deposits generally consist of coarse angular clasts, derived from resistant rocks, that are set in an unsorted matrix of smaller sized clasts, grus, and soil. A striking exception to this general angularity of clasts is the colluvium that contains well-rounded cobbles derived from Browns Park basal conglomerate.

The colluvial deposits include practically all the gold placers that have been productive-those of Ways Gulch, Hahns Peak village, Columbine, and Little Red Park. These deposits extend radially from Hahns Peak and are composed mostly of bleached silicified clasts of the porphyry at Hahns Peak that range in size from pebbles to blocks. Locally, the concentrations of gneiss and pegmatite clasts, derived from the basal part of the Browns Park Formation, and clasts of sandstone or conglomerate, derived from the Dakota Sandstone, are abnormally high, considering the present known limits of their bedrock source area. Moreover, a wide distribution of detrital gold in the placers is not matched by gold occurrence in the intensively explored porphyry bedrock on Hahns Peak; in that bedrock, the small amount of gold still present is virtually restricted to the outer edge of the west side of a breccia pipe. The conclusion is inescapable that the auriferous porphyry and the country rock are lag deposits derived from source rock which was formerly abundant, but which has been virtually stripped by erosion from Hahns Peak.

Age of the colluvium varies widely-probably from early Pleistocene, to Holocene, as in the apronlike placer deposits, to almost the present, as in accumulations of rock chips and blocks in near-bedrock areas.

\section{ALLUVIUM}

Broader parts of the valleys of principal streams of the area are covered with lenticular, generally well sorted silt, sand, gravel, and swamp deposits. Such deposits are also present in the narrower parts of the principal stream valleys and along minor streams; these deposits are too small to be represented on plate 1 . They are auriferous near Hahns Peak, where they have been placered locally, but they are very different in grain size, sorting, and rounding of clasts from the larger, more productive colluvial placers. Most of the alluvium mapped in the Farwell Mountain quadrangle repre- 
sents reworked glacial drift. In Hinman Park the alluvium includes the deposits of low stream terraces.

\section{STRUCTURE}

\section{STRUCTURAL FEATURES IN PRECAMBRIAN ROCKS}

Most of the structural observations recorded for Precambrian rocks in the two quadrangles depict attitudes of a foliation that is approximately parallel to bedding in the metasedimentary rocks. The foliation is expressed both by parallelism of tabular mineral grains and by compositional layering. Folia, generally steeper than $70^{\circ}$, have been complexly folded, producing a zigzag outcrop pattern in the Farwell Mountain quadrangle. Each sharp bend in this pattern is the nose of a nearly isoclinal anticline or syncline. Throughout most of the mapped area, the strikes of axial planes are northeast; however, near Dome Peak, the dominant strike is northwest.

Data for 102 joints in the Precambrian rocks were plotted on the upper hemisphere of the equal-area Schmidt net, according to the method described by Billings (1942). Figure 5 shows the contoured maximums to the poles of the joints. The most prevalent joint set strikes N. $23^{\circ}$ W., which is approximately normal to the general northeast-trending foliation, and it is nearly vertical. Lesser maximums are shown by vertical joint sets that strike N. $86^{\circ}$ E., N. $65^{\circ}$ W., and N. $2^{\circ}$ W.

Lineation is most graphically illustrated in the metaconglomerate that crops out on Farwell Mountain. Rounded pebbles in the conglomerate look equidimensional in horizontal section, but they look more like steeply inclined rods in vertical section because of stretching. In a short distance, the pitch of lineation of the stretched pebbles changes from $63^{\circ}$ toward the northeast to $74^{\circ}$ toward the southwest, thus giving one clue to the complexity of structure in this area.

Microtectonic features noted in the Precambrian rocks are the following: (1) Cataclastic texture in the augen gneiss, exemplified by mortar structure, oscillatory extinction of quartz and feldspar, and bent albite twin lamellae; (2) recrystallization of plagioclase in amphibolite; (3) stretched felsic gneiss pebbles in the metaconglomerate; (4) closely set fractures in bull quartz parallel to foliation in enclosing gneiss; and (5) small but abundant exsolved quartz blebs in microcline of the felsic gneiss.

\section{EARLY TERTIARY FOLDS AND OVERTHRUSTS}

The entire mapped area lies on the west flank of the Park Range uplift. Along this flank the Precambrian-Mesozoic contact reflects several structural highs and lows that are elongated parallel to the 


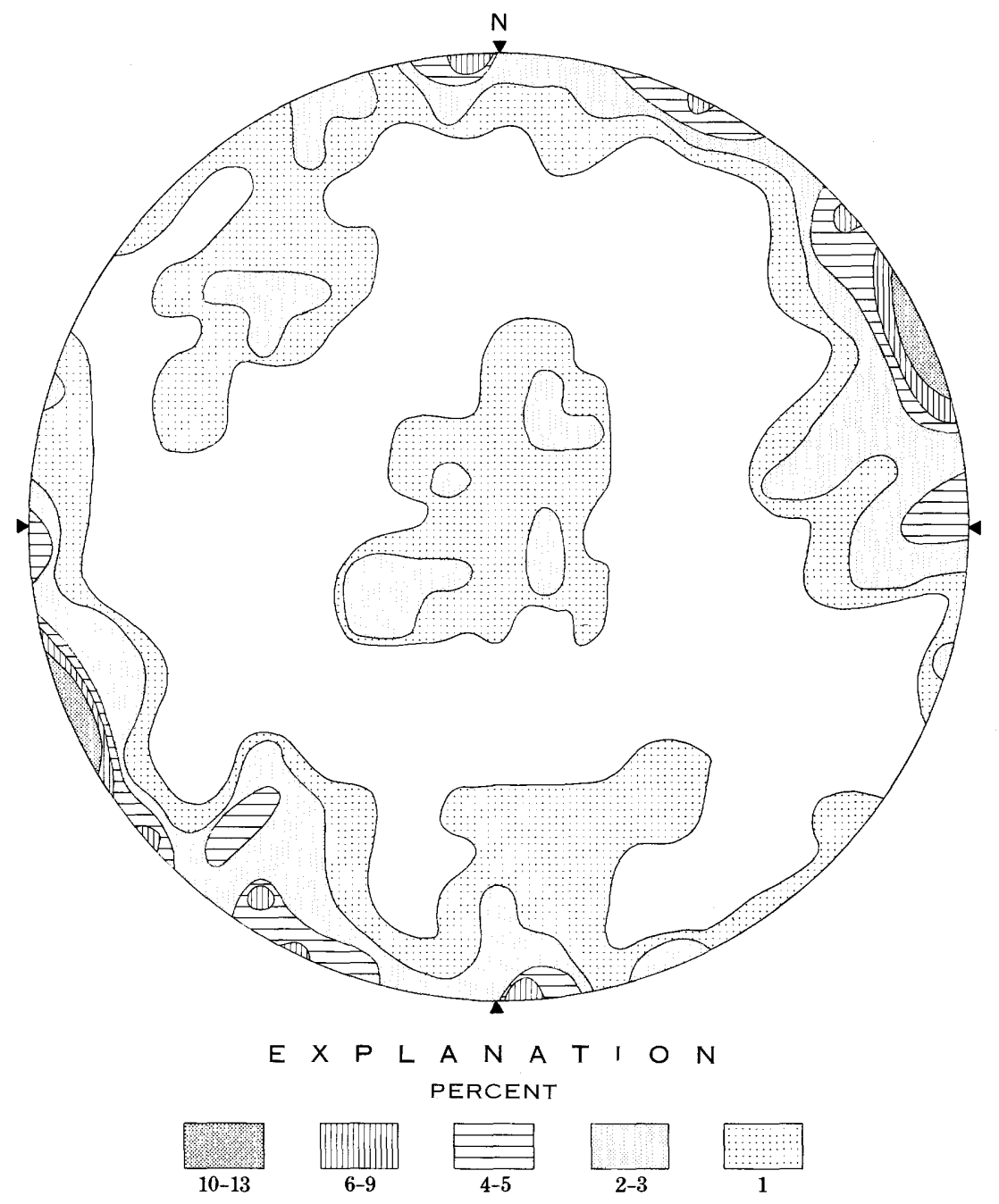

Figure 5. - Contour diagram of poles to 102 joints (upper hemisphere) in Precambrian rocks of the Hahns Peak and Farwell Mountain quadrangles.

Park Range axis. The highs are areas of Precambrian outcrops or of Precambrian rocks directly overlain by the Browns Park Formation. The lows are synclinal areas of Mesozoic outcrops or of Mesozoic rocks concealed by glacial and (or) other overburden. On the east edges of lows, the Mesozoic beds are overthrust by the Precambrian basement. Bedding dips of Mesozoic rocks are generally less than $30^{\circ}$ throughout the greater part of each low, but just west of and under each overthrust, the attitudes of the strata either steepen markedly or overturn. 
Most thrust-fault contacts are obscured by alluvium; but one is exposed along the road between Beaver Creek and Farwell Mountain, near the SW. cor. sec. 11, T. 10 N., R. 85 W. In that area, the shale, 30 feet from the fault—on the east limb of a syncline-dips $50^{\circ}$ E., indicating that the beds are overturned. The fault itself is poorly exposed there both because of crushing and because of ground-water seepage.

Drag between the thrust surfaces has caused the local steepening and overturning, but deformation due to thrusting generally does not extend very far west of the surface trace of the thrust before the deformed beds tend to flatten (sections $A-A^{\prime}, B-B^{\prime}$, and $D-D^{\prime}$, pl. 1). Overturned beds farthest from the thrust that deformed them are those in the Mancos Shale in the S1/2 sec. 33, T. 10 N., R. 85 W., where, in outcrops as much as 2,500 feet away from the trace of the overthrust, the beds are overturned. The overthrust block, which has been stripped away by erosion at that place, must have had a fairly flat dip (about $20^{\circ}$; see western part of geologic section $\left.B-B^{\prime}\right)$. Elsewhere in the area, the thrust planes are probably steeper $\left(30^{\circ}-40^{\circ}\right)$, inasmuch as the influence on underlying beds does not extend very far westward.

The structural highs and lows and the overthrusts affect the Mancos Shale and older rocks, but they do not affect the Browns Park Formation and younger rocks. It is concluded, therefore, that these deformational features were produced during early Tertiary time. In North Park, about 20-30 miles east of the Hahns PeakFarwell Mountain area, the major folds are of post-Pierre age (Late Cretaceous) and pre-Coalmont age (Paleocene and Eocene) (Hail, 1965). Overthrusts in North Park displace the Coalmont Formation, but they are probably older than the White River Formation (Oligocene) ; these overthrusts resemble those of the Hahns Peak-Farwell Mountain area both in attitude and in sense of displacement.

MIOCENE AND PLIOCENE INTRUSIONS, FAULTS, AND TILTING OF BEDS

The west-trending Elkhead Mountains are the loci of many late Tertiary eruptive and intrusive centers, and the dominant strike of fractures there is also west. The western two-fifths of the report area is in that structural environment.

Hahns Peak is the easternmost and best known of the Elkhead igneous bodies. With its central stock and outward-dipping sills, the intrusion resembles a Christmas tree (section $A-A^{\prime}$, pl. 1). Twin Mountain, $11 / 2$ miles to the northeast, is held up by a broad sill, which appears to branch out from the Hahns Peak stock. Exposures of Mancos Shale, as roof pendants and inliers, indicate concordance of the lower intrusive contacts and bedding along the west limb of a syncline whose axis lies just east of Twin Mountain. A 
northwest outlier of the sill at Twin Mountain was proved by drilling to have its floor 40 feet below the surface.

Probably, large parts (if not all) of four Tertiary intrusive outcrop areas south of Hahns Peak also represent one or more sills that dip away from the peak, about $20^{\circ}-40^{\circ} \mathrm{S}$. The dip is confirmed by bedding attitudes in the intruded Mancos Shale, with which the lower intrusive contact is conformable. The four areas underlie Beryl Mountain, Anderson Mountain, Little Mountain, and a hilltop in the SE. cor. sec. 9, T. 10 N., R. 85 W. Other contact relations indicate that a fifth area, in sec. 18, T. 10 N., R. 85 W., may be underlain either by a stock that has an attached sill dipping toward the east and south or by a laccolith that has a similarly dipping floor.

Although many of the intrusive contacts are definitely concordant with bedding in the intruded rocks, some are discordant. Iron Mountain and the hills around Hahns Peak Lake are held up by composite dike-and-sill porphyry bodies. The dikes strike north to west-northwest, and they are as much as 500 feet thick. Other, narrower dikes, which are of diverse strike, intruded the Browns Park Formation and older rocks northeast, east, and southeast of Hahns Peak.

The process of concordant intrusion produced strong doming of the country rock at Hahns Peak and the subsequent collapse of the central part of the stock, where a breccia pipe was formed. The breccia pipe has a diameter of about 3,000 feet at the surface and is roughly cylindrical. Core drilling has shown that the pipe tapers downward slightly and that the Mancos Shale and Browns Park Formation have been dropped about 1,000 feet along the west and northwest walls of the inner pipe. Porphyry at the edges of the pipe is granulated, but inward, the breccia becomes very coarse, and breccia blocks show less and less evidence of rotation. Closely spaced color banding in the pipe is expressed as dark-gray streaks of siliceous rock that contrast with light-gray streaks of less siliceous rock. The banding tends to dip steeply toward the center of the pipe (section $A-A^{\prime}$, pl. 1).

A west-striking horst-and-graben structure is evident in the Hahns Peak and Farwell Mountain quadrangles.

The horst at Hahns Peak and vicinity is bounded by the King Solomon fault on the north and by the Grouse Mountain fault on the south. Both faults are poorly exposed. Vertical displacement along the King Solomon fault is about 600 feet at section $C-C^{\prime}$ (pl. 1), where the Browns Park Formation probably directly overlies Precambrian rocks on the north side of the fault. This stratigraphy was shown by core drilling at a locality 200 feet north of the fault (marked by drill-hole symbol on map); there, the drilling was 
stopped about 8 feet below the Browns Park-Precambrian contact (W. A. Bowes, oral commun., 1967). Mesozoic strata on the south side of the fault are about 2,000 feet thick at section $C-C^{\prime}$, as inferred from nearby outcrops. Westward deflection of the Dakota Sandstone on the south side of the King Solomon fault is attributed to the left-lateral movement of about 600 feet along the fault, in the NW1/4, sec. 2, T. 10 S., R. $85 \mathrm{~W}$. The Grouse Mountain fault resembles the King Solomon fault in strike and length, but its maximum vertical displacement is probably not more than 500 feet. The horst is complexly broken by smaller faults. Study of percussion drilling along the road just west of Little Mountain indicates that a narrow west-striking block of Jurassic siltstone (Morrison?) is elevated about 300 feet between a pair of faults.

The broad shallow graben at Steamboat Lake is south of the Hahns Peak horst (section $C-C^{\prime}$, pl. 1). The graben is bounded on the south by the Steamboat Lake fault, which has a maximum displacement of only 125-150 feet; a dike at the southwest edge of the lake branches from the fault, filling a west-northwest-trending fracture. The Spillway fault, a west-northwest-trending fracture within the graben, duplicates the amount of displacement of the Steamboat Lake fault.

North of the Hahns Peak horst, a narrow graben lies between the King Solomon fault and the Silver City Creek fault. Neither fault is exposed along the sides of the graben, and inasmuch as no drilling has been done there, the amounts of displacement are only conjectural.

Map relations reflect only post-Browns Park movement on the west-striking faults. However, the subsurface relations near the north end of section $C-C^{\prime}$ suggest that there may have been at least two periods of movement on the King Solomon fault, one which was post-Mesozoic and pre-Browns Park and one which was post-Browns Park. During the first period, however, some 2,000 feet of vertical displacement is believed to have occurred at the north end of section $C-C^{\prime}$ and the displacement moved the north side up, not down, as shown on the map (pl. 1). This upward displacement would account for erosional stripping of the Mesozoic north of the King Solomon fault in the western part of the area before deposition of the Browns Park Formation. Farther east (at the head of King Solomon Creek), the amount of erosional stripping of the Mesozoic north of the King Solomon fault would have been less, indicating that the north side of the fault was displaced downward, rather than upward, and that a scissors action characterized the first-period movement on the King Solomon fault. Then, during the second period of movement, the north side of the fault was displaced about 600 feet downward (as shown on pl. 1), both in the vicinity of sec- 
tion $C-C^{\prime}$ and at the head of King Solomon Creek. Thus, the displacements tended to cancel each other in the western area, but they were cumulative in the eastern area.

Horizontal displacement could also account for the mismatching of rocks on the two sides of the King Solomon fault along section $C-C^{\prime}$. If we assume that the Precambrian high in the subsurface at the north end of section $C-C^{\prime}$ corresponds to the Precambrian high in sec. 12 , T. 10 N., R. 85 W., then a left-lateral displacement of at least $21 / 2$ miles had to have occurred. A horizontal displacement of this magnitude is difficult to attribute to a fault that seems to fade out between Little Farwell Mountain and Dome Peak. The scissorsaction concept presented in the preceding paragraph is not easy to accept, as it requires a large reversal in the vertical displacement of the fault, but it seems to offer a more satisfactory explanation than that of a much larger lateral displacement.

Local tilting and warping of beds in the Browns Park Formation and of already deformed older beds can be attributed to the highangle faulting. Two synclines near the southwest corner of the area strike northeast, and the maximum dip of their limbs is $13^{\circ}$. Dips of Browns Park beds, from $10^{\circ}$ to $24^{\circ}$, are visible in roadcuts north of Steamboat Lake. In general, the bedding attitudes attributable to block tilting and warping are not so steep as those attributable to intrusive doming, which are as much as $40^{\circ}$ near Hahns Peak.

Times of latest movement along the three faults and of other west- to northwest-striking high-angle faults in the Hahns Peak and Farwell Mountain quadrangles appear to coincide with the Pliocene age of the porphyry intrusives of the region. Many of the fractures existed before intrusion and provided structural control for emplacement of some of the porphyry bodies ; for example, those in the NW. cor. sec. 2 , T. 10 N., R. 85 W. Other preexisting fractures, such as the King Solomon fault, apparently did not provide a structural control for intrusion and do not show evidence of significant postporphyry movement. In sec. 18 , T. 10 N., R. 85 W., however, there are postporphyry shears.

\section{GEOMORPHOLOGY}

\section{PRE-BROWNS PARK EROSION SURFACE}

According to Buffler (1967), a broad erosion surface extended across the west flank of the Park Range and sloped gently westward across the present area of the Elkhead Mountains, in pre-Browns Park time.

The surface is recognized as the basal contact of the lowermost unit of the Browns Park Formation, usually conglomerate. The position of this surface just prior to the Browns Park deposition can be inferred partly from observations of the contact, partly from the 
absence of the Browns Park Formation in other areas, and partly from reconstruction of known post-Browns Park structural events. The topography of this surface was generally high where it truncated Precambrian rocks and lower where it truncated Mesozoic rocks. In a few places, as in Little.Red Park and at the north end of structure section $C-C^{\prime}$, the Precambrian topography is low. Most of the surface has been buried by basal conglomerate or by sandstone of the Browns Park Formation, patches of which are mapped on plate 1. A patch of conglomerate 0.4 mile northwest of the Farwell mine and two smaller outcrops of sandstone between Scott Run and the North Fork Elk River indicate that the present surface at these high altitudes is close to the ancient one.

In Mesozoic terrane of the horst between the King Solomon fault and the Grouse Mountain fault, the pre-Browns Park surface is exposed at many places along the Browns Park-Mancos Shale contact, but, in the Steamboat Lake graben (p. 50) to the south, the surface is buried by the Browns Park Formation to depths of at least 163 feet, as shown by drilling west of the lake. This burial was indeed much greater in late Browns Park time. On Sand Mountain, 3 miles west of the Hahns Peak quadrangle, at least 900 feet of Browns Park is exposed; there, a protective lava cap has preserved the Browns Park sandstone from erosion.

The pre-Browns Park erosion surface implies that the Browns Park sandstone is a time equivalent of the Browns Park conglomerate where the conglomerate is absent from the base of the formation-or that deposition of the conglomerate was closely followed by that of the sandstone. Unfortunately, there is no evidence, such as fossils or ash beds, that proves this time equivalence in the study area. An alternative explanation is that the conglomerate accumulated as reworked lag deposits over a long period of time and that the present buried Precambrian surface may not have been formed at the same time throughout its extent. There is no evidence, such as conglomerate over sandstone or conglomerate as a lateral facies of sandstone, to indicate that the sandstone deposition closely followed the conglomerate deposition. These considerations lead us toward the conclusion that the pre-Browns Park erosion surface was of different ages at different places.

\section{DEVELOPMENT OF THE MODERN LANDSCAPE}

The modern landscape at Hahns Peak and at Farwell Mountain began to develop some time after deposition of the Browns Park. The presence of conglomerate 0.4 mile northwest of the Farwell mine and of sandstone between Scott Run and the North Fork Elk River indicates that the deposits lapped up onto the mountains to at least 9,440 feet. (See pl. 1.) The apparent absence of remnants of 
the Browns Park Formation at higher altitudes suggests that Farwell Mountain, Dome Peak, and the mountain at the northeast corner of the Farwell Mountain quadrangle all rose above the broad ramplike depositional surface that sloped away from the mountains. The ramp was deformed by doming at Hahns Peak and by east-west faulting north and south of the peak. As dissection progressed, major streams (for example, Willow Creek) were superposed on the Browns Park cover. East and south of Farwell Mountain, the erosion cycle was subsequently interrupted by glacial deposition, which, in turn, was followed by superposition of Coulton Creek and Hinman Creek on the drift cover.

Today, most of the two quadrangles is a dissected upland. Some of the highest rocks are those which were emplaced in the western part of the area during the period of burial. The Tertiary intrusives owe their present height partly to a high level of magmatic emplacement, partly to structural doming and faulting, and partly to resistance to erosion after emplacement. Other resistant rocks are those of the Dakota Sandstone and the Precambrian basement complex. The Mancos Shale and the Jurassic and Triassic formations are relatively less resistant and underlie mountain valleys. Hahns Peak is an exceptionally bold, isolated hill of silicified porphyry that rises as much as 2,000 feet above the surrounding terrain. Its north shoulder is held up by a cap of silicified Dakota Sandstone. Farwell Mountain, Dome Peak, and the area between Scott Run and the North Fork Elk River are bold massifs of Precambrian gneiss.

The erosion of Hahns Peak is atypical. Because the surface rock is thoroughly fractured, perhaps as a result of intense frost action, there is no surface runoff. During a very hard rain, the water can be heard rushing through unseen crevices far below the surface. On a warm day in early spring, subterranean melt water from the snow cover can also be heard, but not seen. Thus, the peak is not worn down by surface water, but by the slow creeping and grinding of talus blocks accompanied by subterranean flushing.

A common phenomenon throughout the area is the development of "knees" low on the trunks of trees-particularly aspens-where the angle of the tree trunks changes from right angles to the mountain slope (or even horizontal at the base) to vertical. Striking examples of sporadic felling of saplings by avalanches, followed by renewed upward growth, are thus illustrated. The old Trail Creek diversion canal along the south slope of Farwell Mountain has been obliterated by soil creep and avalanche deposition. The deposits of mass wastage large enough to be classed as landslides are shown on plate 1 and are described in the section on Quaternary deposits.

A major stream has been beheaded in the northeast quarter of 
the Farwell Mountain quadrangle. Scott Run is an underfit stream that heads on a low divide at the west end of Diamond Park and flows west-southwest to join Hinman Creek. The stream formerly headed on Mount Zirkel, much farther to the east, but the drainages through Diamond Park and from a major tributary, Trail Creek, were cut off and diverted southward by the North Fork Elk River.

Artificial stream diversions were made at several places for placer mining operations during 1880-1910. Before two diversion channels were cut into the sandstone of the Browns Park by placer miners, Ways Gulch joined Beaver Creek near the SE. cor. sec. 27, T. 10 N., R. $85 \mathrm{~W}$.; now, Ways Gulch drains into a formerly dry gulch that enters Willow Creek just below the Steamboat Lake dam. Upper Trail Creek was tapped by a canal which channeled the water through a Dakota Sandstone ledge (via a tunnel $200 \mathrm{ft}$ long) to Hinman Creek. From Hinman Creek the water was conveyed by ditch around the southeast flank of Farwell Mountain, through another tunnel, and, thence, across the upper valley of Beaver Creek and its tributaries to the old placer diggings of Ways Gulch and Hahns Peak village.

Hahns Peak shows no evidence of glaciation, despite its great altitude. A cirque at Farwell Lake and glacial grooves and polished outcrops near the lake, and 1-2 miles farther north, show that small glaciers existed just east of the crest of Farwell Mountain. Dome Peak has no recognizable cirque, but grooves and roche moutonnees on the peak indicate that small glaciers also existed on the east side of that massif. The ridge between Scott Run and the North Fork Elk River protruded at least 250 feet above the highest lateral moraine now present on its east flank.

Not all the landforms of the area are represented by erosional features. Poorly drained morainal topography is exceptionally well preserved in a 2-square-mile area between Trail and Stevens Creeks, in the northeast quarter of the Farwell Mountain quadrangle, where swamps and shallow ponds lie between bouldery ridges that are as much as 40 feet high; no appreciable amount of erosion has occurred there since glacial deposition.

Steamboat Lake, Lester Creek Reservoir, and Hahns Peak Lake, as well as about 10 smaller lakes and at least 100 small ponds, are in the mapped area. The larger lakes are reservoirs impounded by artificial dams. Farwell Lake is a tarn; it occupies an ice-gouged basin in the floor of a cirque. Hinman Lake and other lakes located on interfluves to the east are dammed by morainal deposits. Lake "8271," which is about 1.4 miles north-northeast of Hinman Lake, is dammed by a blockslide of Dakota Sandstone. And, the numerous 
small ponds formed along many of the watercourses have been impounded by beaver dams.

Most of the morainal lakes are very shallow and are becoming filled with peat and other swamp deposits. A good example of one of these "dying" lakes is the one at the northernmost head of Scott Run, immediately west of hill " 8808 ," in the northeast quarter of the Farwell Mountain quadrangle. Another body of water, just west of lake "8271" - large enough to include on the Farwell Mountain topographic map in 1962-has since completely filled with silt.

\section{GEOLOGIC HISTORY}

A sequence of sedimentary and volcanic rocks was deposited over the area during Precambrian time. The sediments were pelitic, arenaceous, and, very locally, conglomeratic. The presence of sedimentary structural features, such as crossbedding, and the almost complete absence of carbonate rocks suggest that most of the sequence was deposited subaerially. Intercalations of mafic volcanic rocks are abundant. The sedimentary and volcanic rocks were regionally metamorphosed into gneisses and schists of the almandineamphibolite mineral facies. Schistosity that developed during early isoclinal folding of the metamorphic rocks was later deformed into open folds striking east-northeast. Granite and quartz diorite intruded the sequence during one or both periods of tectonism; veins and pods of pegmatite and quartz, containing minor amounts of sulfides, were introduced during a late phase of the tectonic activity. Radiometric dating of rocks and minerals indicate that the latest metamorphic and magmatic events affecting the Precambrian sequence occurred 1.65-1.7 b.y. (billion years) ago. The succeeding years up to Permian time are a blank, as far as the local record is concerned. From evidence obtainable elsewhere in the region, deductions can be made that the rocks were uplifted, eroded, and possibly submerged several times during that long time interval.

The Paleozoic Era is represented by the Permian Goose Egg Formation.

The Mesozoic Era opened with subaerial deposition of the Red Peak Formation. This deposition was followed by erosion and some tilting and warping of beds. Later, in Triassic time, the Jelm Formation, of fluviatile origin, was deposited. In Late Triassic time the Popo Agie Formation and the lower part of the Nugget Sandstone were deposited in environments that changed progressively from fluviatile to lacustrine to tidal-flat. Uplift and erosion in Early Jurassic time are recorded by truncation of the Triassic rocks by an erosion surface. Submergence in a Late Jurassic sea is recorded by burial of this erosion surface under a thin sequence of marine beds assigned to the Sundance Formation. Withdrawal of the sea was 
followed by deposition of the Morrison Formation in a low-gradient fluviatile and lacustrine environment. Uplift of the Park Range in earliest Cretaceous time sharpened relief of the land and resulted in rapid erosion of Precambrian rocks and deposition of coarse clastic sediments of the Dakota Sandstone. Subsequent transgression of a vast Cretaceous sea produced widespread deposition of marine beds, chiefly shale, of the Mancos Shale.

The marine environment was ended by uplift of the Rocky Mountains (Laramide Revolution), which began in Late Cretaceous time and continued into early Tertiary time. Major open folding then took place along north- to northwest-trending axes. The anticlinal crests were stripped of their sedimentary cover, exposing the Precambrian crystalline core. Westward thrusting of anticlinal Precambrian rocks over synclinal Mesozoic rocks took place during a late phase of the Laramide tectonic activity-probably in late Eocene time. No deposits of Paleocene, Eocene, or Oligocene age occur in the area, indicating either nondeposition during these epochs or complete removal by erosion of any lower Tertiary rocks that may have been deposited.

At the beginning of Miocene time a ramplike erosion surface, probably of low relief, sloped away from the Precambrian highland of the Park Range. A veneer of gravel which had developed over the surface was subsequently buried by the eolian and fluviatile sand of the Browns Park Formation. Interbeds of airborne ash, from distant sources, were deposited in the predominantly sand sequence. Browns Park deposition continued through the Miocene Epoch and probably into early Pliocene time, when, locally, volcanism and intrusion began. Doming accompanied intrusion of the porphyry at Hahns Peak, which occurred about 12 m.y. ago, and rock alteration resulted from hydrothermal activity. An explosive blowout at Hahns Peak resulted in deposition of the tuffaceous epiclastic breccia, which is preserved on the hill 1 mile west-northwest of the peak. Renewed intrusion and doming produced strong tilting of beds near Hahns Peak. Episodic collapse in the center of the intrusive at Hahns Peak produced a breccia pipe. Silicification and metalization of the pipe and of a zone extending northwestward beyond the Master Key mine were late features of the intrusive period.

The remainder of the Pliocene Epoch was characterized by differential movements of large blocks. The blocks were displaced vertically and laterally, chiefly along west-trending faults, and they were also tilted and warped.

Uplift in Quaternary time sharpened relief and increased the rate of erosion. Although most of the Browns Park Formation was stripped from upthrown blocks, such as the Hahns Peak horst 
(p. 49), it remained well preserved on downthrown blocks, such as the Steamboat Lake graben (p. 50). A long erosion cycle was interrupted by widespread glaciation in the Farwell Mountain quadrangle and in the Park Range, to the east, north, and south. Moraines of different degrees of preservation show evidence of at least three ice advances, which are somewhat tenuously correlated with glacial deposits in the Wind River Range of southwestern Wyoming.

Mass wastage has been a dominant process during much of Holocene time. Landslides and colluvial deposits, which continue to accumulate today, tend to cover mountain slopes of the area, obscuring earlier evidence of the local and regional history.

\section{REFERENCES CITED}

Atwood, W. W., Jr., 1937, Records of Pleistocene glaciers in the Medicine Bow and Park Ranges [Wyoming and Colorado]: Jour. Geology, v. 45, no. 2, p. $113-140$.

Barnwell, W. W., 1955, The geology of the south Hahns Peak district, Routt County, Colorado, in Guidebook to the geology of northwest Colorado, Intermountain Association of Petroleum Geologists, 6th Annual Field Conference, 1955: Salt Lake City, Utah, p. 73-74.

Billings, M. P., 1942, Structural geology [1st ed.]: New York, Prentice-Hall, Inc., $473 \mathrm{p}$.

Blackwelder, Eliot, 1915, Post-Cretaceous history of the mountains of central western Wyoming: Jour. Geology, v. 23, p. 97-117, 193-217, 307-340.

Buffler, R. T., 1967, The Browns Park Formation and its relationship to the late Tertiary geologic history of the Elkhead region, northwestern Colorado-south-central Wyoming: California Univ. Ph. D. thesis; Ann Arbor, Mich., Univ. Microfilms, Inc., 215 p.

Gale, H. S., 1906, The Hahns Peak gold field, Colorado: U.S. Geol. Survey Bull. 285-A, p. 28-34.

George, R. D., and Crawford, R. D., 1909, The Hahns Peak region, Routt County, Colorado: Colorado Geol. Survey 1st Rept., 1908, p. 189-229.

Hague, Arnold, and Emmons, S. F., 1877, Descriptive geology: U.S. Geol. Explor. 40th Parallel (King), v. 2, 890 p.

Hail, W. J., Jr., 1965, Geology of northwestern North Park, Colorado: U.S. Geol. Survey Bull. 1188, 133 p.

1968, Geology of southwestern North Park and vicinity, Colorado: U.S. Geol. Survey Bull. 1257, 119 p.

Hunter, J. M., 1955, Geology of the north Hahns Peak area, Routt County, Colorado, in Guidebook to the geology of northwest Colorado, Intermountain Association of Petroleum Geologists, 6th Annual Field Conference, 1955: Salt Lake City, Utah, p. 71-72.

Imlay, R. W:, 1947, Marine Jurassic of Black Hills area, South Dakota and Wyoming: Am. Assoc. Petroleum Geologists Bull., v. 31, no. 2, p. 227-273.

Izett, G. A., 1968, Geology of the Hot Sulphur Springs quadrangle, Grand County, Colorado: U.S. Geol. Survey Prof. Paper 586, 79 p.

Kinney, D. M., 1955, Geology of the Uinta River-Brush Creek area, Duchesne and Uintah Counties, Utah: U.S. Geol. Survey Bull. 1007, 185 p.

McConnell, M. D., 1960, The geology of the Clark-Hinman Park area, Routt County, Colorado: Wyoming Univ. unpub. M.A. thesis, 67 p. 
McDowell, F. W., 1966, Potassium-argon dating of Cordilleran intrusives: Columbia Univ. Ph. D. thesis; Ann Arbor, Mich., Univ. Microfilms, Inc. MeIntyre, D. B., Welday, E. E., and Baird, A. K., 1965, Geologic application of the air pycnometer-A study of the precision of measurement: Geol. Soc. America Bull., v. 76, no. 9, p. 1055-1060.

Murphy, Richard, 1958, Geology of the Slavonia-Diamond Park area, Routt County, Colorado: Wyoming Univ. unpub. M.A. thesis, 54 p.

Nockolds, S. R., 1954, Average chemical compositions of some igneous rocks: Geol. Soc. America Bull., v. 65, no. 10, p. 1007-1032.

Peterman, Z. E., Hedge, C. E., and Braddock, W. A., 1968, Age of Precambrian events in the northeastern Front Range, Colorado: Jour. Geophys. Research, v. 73, no. 6, p. 2277-2296.

Pipiringos, G. N., 1957, Stratigraphy of the Sundance, Nugget, and Jelm formations in the Laramie Basin, Wyoming: Wyoming Geol. Survey Bull. 47, $63 \mathrm{p}$.

1968, Correlation and nomenclature of some Triassic and Jurassic rocks in south-central Wyoming: U.S. Geol. Survey Prof. Paper 594--D, $26 \mathrm{p}$.

Pipiringos, G. N., Hail, W. J., Jr., and Izett, G. A., 1969, The Chinle (Upper Triassic) and Sundance (Upper Jurassic) Formations in north-central Colorado: U.S. Geol. Survey Bull. 1274-N, 35 p.

Poole, F. G., and Stewart, J. H., 1964, Chinle Formation and Glen Canyon Sandstone in northeastern Utah and northwestern Colorado, in Geological Survey research 1964: U.S. Geol. Survey Prof. Paper 501-D, p. D30-D39 [1965].

Richmond, G. M., 1960, Glaciation of the east slope of Rocky Mountain National Park, Colorado: Geol. Soc. America Bull., v. 71, no. 9, p. 1371-1381.

Rittmann, Alfred, 1952, Nomenclature of volcanic rocks proposed for the use in the catalogue of volcanoes, and key tables for the determination of volcanic rocks: Bull. Volcanol., ser. 2, v. 12, p. 75-102; discussion, p. 24-26.

Segerstrom, Kenneth, and Kirby, S. H., 1969, Tuffaceous epiclastic breccia and sandstone near Hahns Peak, Colorado, and their genetic implications in Geological Survey research 1969 : U.S. Geol. Survey Prof. Paper 650-B, p. B19-B22.

Tuttle, O. F., and Bowen, N. L., 1958, Origin of granite in the light of experimental studies in the system $\mathrm{NaAl}_{3} \mathrm{O}_{8}-\mathrm{KAlSi}_{3} \mathrm{O}_{8}-\mathrm{SiO}_{2}-\mathrm{H}_{2} \mathrm{O}$ : Geol. Soc. America Mem. 74, 153 p.

U.S. Geological Survey, 1965, Geological Survey research 1965: U.S. Geol. Survey Prof. Paper 525-A, p. A88.

U.S. Weather Bureau, 1960, Precipitation data from storage-gage stations, in Climatography of the United States, Nos. 70-2 (Arizona), 70-5 (Colorado), and 70-29 (New Mexico): $54 \mathrm{p}$.

VanderPlas, L., and Tobi, A. C., 1965, A chart for judging the reliability of point-counting results: Am Jour. Sci., v. 263, no. 1, p. 87-90. 


\section{INDEX}

[Italic page numbers indicate major references]

A

Accessibility.

Acknowledgments

Age, Bell Springs Member, Nugget Sandstone.

18 ,

Browns Park Formation

31,32

Bull Lake (?) Till.

.. 43,44

Canyon Springs Sandstone Member, Sundance Formation.............. 26, 27

colluvium.

Dakota Sandstone...

Entrada Sandstone.

epiclastic volcanic rocks..

extrusive rocks.

Hulett Member, Sundance Formation intrusive rocks.

Jelm Formation. $18,19,22$

Lak Member, Sundance Formation....

Mancos Shale

Morrison Formation.

Nugget Sandstone, lower part..............

Pine Butte Member, Sundance Formation.

Pinedale Glaciation.

Pinedale (?) Till.

Popo Agie Formation.

porphyry at Hahns Peak

pre-Bull Lake till.

Precambrian rocks

radiometric, magmatic events.

range, Quaternary deposits.

Redwater Shale Member, Sundance

$$
\text { Formation.. }
$$

Sundance Formation

..... 26,28

26,27

44

43

18,19

56

42

16,17

55

42

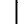

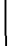

Alluvium

Alteration, hydrothermal, Morrison Formation.

hydrothermal, porphyry

Itered gneiss. See Gneiss, altered.

Amphibolite.

analyses.

hydrothermally altered zones.

sample localities.

slabs, Browns Park conglomerate......

Amphibolite complex..

Analyses, contact metamorphic rock........

metamorphic rocks.

Tertiary igneous rocks.

... 38, 39

types.

$\mathrm{X}$-ray.

35,36 ,

37, 56

Artis, Lowell, chemical analyst

10,38

Ash, volcanic, Browns Park Formation.... 32, 56 Augen gneiss. See Gneiss, augen.

Avalanches.

\section{B}

Page

Basement complex

Beaver dams....................... 55

Bedding characteristics, augen gneiss......... 15

biotite gneiss.......................................... 12

Browns Park Formation..................... 32

Jelm Formation...................................... 19

Mesozoic rocks.......................................... 47

Pine Butte Member, Sundance For-

mation........................................ 27
quartzite

schist.......................................................... 13

Belemnites, Redwater Shale Member, Sundance Formation.

Member, Nugget Sandstone

18 ,

19,24

35

Biotite, potassium-argon age........................ 41

Biotite gneiss. See Gneiss, biotite.

Botts, S. D., chemical analyst................. 10, 38

Boulder Creek Granite, radiometric dating 18

Breccia pipe, geologic history.................... 56

Browns Park Formation............................. $s 1$

deformation........................................... 51

geologic history........................................ 56

Browns Park sandstone, correlation.......... 52

Brynt Draw Member, Popo Agie Formation, fossils

Buffler, R. T., potassium-argon ages, rocks in Elkhead Mountains 41 quoted..

Bull Lake ( ?) Till...........................................

\section{C}

Canyon Springs Sandstone Member, Sundance Formation.

Cardioceras zone, Redwater Shale Member, Sundance Formation....

Chinle Formation......................................... 24

Chloe, Gillison, chemical analyst............... 10, 38

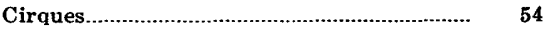

Climate......................................................... 5

Cloverly Formation......................................... 30

Cobban, W. A., quoted................................. 31

Colluvium..................................................... 45, 57

Composition, altered gneiss.......................... 15

amphibolite.................................................... 8

amphibolite complex ................................... 9

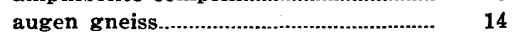

biotite gneiss............................................ 12

felsic gneiss.................................................. 7

garnet-epidote skarn............................... 16

intrusive porphyries................................ 34

metaconglomerate..................................... 9 
Composition, altered gneiss - Continued phenocrysts. quartz diorite gneiss quartzite. schist.

Contact metamorphic rocks

Contact relations, Bell Springs Member, Nugget Sandstone

Browns Park Formation.

Canyon Springs Sandstone Member, Sundance Formation..

Dakota Sandstone.

epiclastic volcanic rocks

Goose Egg Formation.

Jelm Formation.

Mancos Shale

Morrison Formation

Pine Butte Member, Sundance Formation

Popo Agie Formation

Red Peak Formation.

Redwater Shale Member, Sundance Formation

Windy Hill Sandstone Member, Sundance Formation.

Correlation, Bell Springs Member, Nug get Sandstone...

Browns Park Formation

Brynt Draw Member, Popo Agie Formation

Bull Lake Glaciation and Bull Lake (?) Till.

Canyon Springs Sandstone Member, Sundance Formation.

Chinle Formation, lower member.....

Dakota Sandstone.

Jelm Formation..

Lyons Valley Member, Popo Agie Formation.

Triassic and Jurassic rocks along Sierra Madre-Park Range uplift.

Crandell, W. B., spectrographic analyst 10,18

Cretaceous rocks

Cretaceous sea............................................... 56

\section{D}

Dakota Sandstone.

Deformation, geologic history.

Miocene and Pliocene

Depositional environment, Bell Springs Member, Nugget Sandstone

Browns Park Formation

Brynt Draw Member, Popo Agie Formation.

Chinle Formation, lower member......

Jelm Formation.

Lyons Valley Member, Popo Agie Formation.

Morrison Formation.

Sundance Formation.

Windy Hill Member.

Dikes

Dome Peak, amphibolite

Doming, at Hahns Peak.

Drainage.
Page

35,36

15

14

13

41
E

Page

Elmore, P. D. L., chemical analyst.... 10, 38, 42

Emmons, S. F., and Hague, A., quoted.... 37

Engleman, E. E., standard-rock analyst 38

Entrada Sandstone, age............................... 27

Environment, depositional. See Depositional environment.

Eocene rocks, Elkhead Mountains............. $\quad 32$

Erosion surface, pre-Browns Park........... 51

Erratics, glacial........................................... 43, 44

Extrusive rocks, age, potassium-argon... 40

\section{$\mathbf{F}$}

Farwell Mountain, amphibolite

8,9

Faults................................................. 47, 48, 56

Felsic gneiss complex. See Gneiss complex, felsic.

Felsic-mafic index, igneous rocks............... 34

Fieldwork........................................................ 5

Fish scales, Mancos Shale........................... 31

Flow rocks....................................................

Folds, early Tertiary ...................................... 46

Foliation, altered gneiss.............................. 15 augen gneiss....................................... 15

biotite gneiss............................................ 12

felsic gneiss............................................. 7

Precambrian rocks................................... 46

quartz diorite gneiss.............................. 15

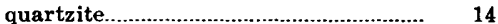

schist........................................................ 13

Forest fires, Farwell Mountain quadrangle 6

Fossils, Browns Park Formation................ 33

Brynt Draw Member, Popo Agie Formation.

Mancos Shale

Pine Butte Member, Sundance Formation

Redwater Shale Member, Sundance Formation.

Fractures, altered gneiss

\section{G}

Garnet-epidote skarn. See Skarn, garnetepidote.

Geochemical studies, previous....................... Geography......................................................

Geologic history ............................................ 55

Geomorphology, pre-Browns Park erosion surface

Geophysical studies, previous work........... Glacial deposits.

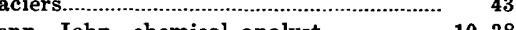

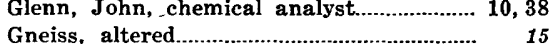

augen...................................................... 14

analyses.......................................... 10

rubidium-strontium age................. 16, 17

sample locality.................................. 11

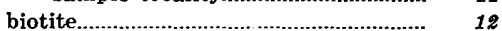

analyses........................................... 10

sample localities............................... 11

felsic..

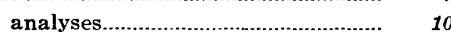


Gneiss, altered - Continued

felsic - Continued

Browns Park Formation

dikes intruding.

hydrothermally altered zones.......

rubidium-strontium age.

sample locations.

quartz diorite.

analyses

sample localities

Gneiss complex, felsic

felsic, analyses. sample localities

Gold placers.

Goose Egg Formation.

Gravels, terrace

Grouse Mountain fault

$\mathrm{H}$

Hague, A., and Emmons, S. F., quoted....

Hahns Peak, atypical erosion.

episodic collapse of intrusive.

historic landmark

horst.

hydrothermally altered porphyry........ metals exploration

Harris, J. L., spectrographic analyst......... 10, 38

Hedge, C. E., analyst, rubidium-strontium data

Hinman Canyon, felsic gneiss.

Hinman Glacier, till deposits.

Hoybacks, Browns Park conglomerate...

Hole-in-Wall Canyon, felsic gneiss............

Holocene mass wastage

Hornblende, potassium-argon age...............

Hulett Member, Sundance Formation......

Hydrothermal alteration, Morrison Formation

porphyry.

\section{I, J, $\mathbf{K}$}

Igneous rocks, felsic-mafic ratio.

Industries, principal.

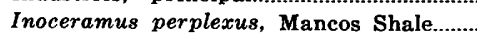

Inoceramus (Haploscapha) grandis, Mancos Shale.

Intrusive rocks

episodic collapse at Hahns Peak........

Miocene and Pliocene

potassium-argon age

Jelm Formation geologic history source.

Joints, Precambrian rocks

Jurassic rocks, post-Sundance. pre-Morrison

Jurassic sea, Late.

Kelsey, James, chemical analyst King Solomon fault

\section{$\mathbf{L}$}

Lak Member, Sundance Formation. Lakes in area, origin. 49,50

\begin{tabular}{|c|c|}
\hline Page & \\
\hline 32 & $\begin{array}{l}\text { Landscape, modern, development...................... } \\
\text { Landslide deposits. }\end{array}$ \\
\hline 36 & 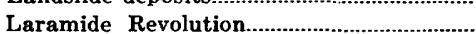 \\
\hline 16 & Lineation, metaconglomerate. \\
\hline 6,17 & Precambrian rocks................. \\
\hline 11 & Lithology, alluvium.. \\
\hline 15 & altered gneiss.. \\
\hline 10 & amphibolite.. \\
\hline 11 & amphibolite complex....... \\
\hline 8 & augen gneiss.. \\
\hline 10 & Bell Springs Member, Nugget Sand- \\
\hline $\begin{array}{l}11 \\
45\end{array}$ & \\
\hline $\begin{array}{r}45 \\
18,55\end{array}$ & biotite gneiss... \\
\hline 18,55 & Browns Park Formation... \\
\hline 49,50 & $\begin{array}{c}\text { Canyon Springs Member, Sundance } \\
\text { Formation }\end{array}$ \\
\hline
\end{tabular}

Page

52

44,57

56

12

46

45

15

8

9

14

25

12

32

colluvium

26

45

contact metamorphic rocks................... 41

Dakota Sandstone................................... 29, 30

dark quartz............................................... 15

felsic gneiss...................................................

felsic gneiss complex............................. $\quad 8$

garnet-epidote skarn ................................ 15

Goose Egg Formation............................. 18

Hulett Member, Sundance Formation $\quad 26$

Jelm Formation.................................... 19

Lak Member, Sundance Formation.... 26

Mancos Shale.......................................... $\quad 30$

metaconglomerate........................................ 9

Morrison Formation................................ $\quad 29$

pegmatite.............................................. 16

Pine Butte Member, Sundance Formation................................. 27

Popo Agie Formation............................. 24

quartz diorite gneiss.............................. 15

quartzite................................................. 14

Red Peak Formation............................ 18

Redwater Shale Member, Sundance Formation................................ 28

schist......................................................... 18

Sundance Formation............................... 26

Troublesome Formation.......................... 33

tuffaceous epiclastic rocks.................... $\quad 34$

Little Farwell Mountain, amphibolite...... 8

Location of quadrangles.............................. 2

31 Lopha, Pine Butte Member, Sundance Formation.

Lyons Valley Member, Popo Agie Formation, correlation

M

18, 19 McDowell, F. W., potassium-argon age of biotite.

41

Magmatic events, radiometric dating........ $\mathbf{5 5}$

Mancos Shale............................................. 30,56

Marvin, R. F., potassium-argon data, analyst..................................... 17, 41

Mass wastage, Holocene................................ 57

Mehnert, H. H., potassium-argon data, analyst................................. 17, 41

Merritt, Violet, potassium-argon data, analyst..................................... 17, 41

Mesozoic Era.................................................

26 Mesozoic rocks, outcrops............................... 47

54 Metaconglomerate............................................. 9 
Metalization, breccia pipe

Metals exploration, Hahns Peak

Metamorphic rocks, analyses. contact

$$
\text { analyses.... }
$$

sample localities

Metamorphism, regional.

Microtectonic features, Precambrian rocks

Minerals, exploration, previous work....... intrusive and flow rocks.

principal, altered gneiss. amphibolite

augen gneiss.

biotite gneiss

felsic gneiss

felsic gneiss complex.

garnet-epidote skarn

phenocrysts.

quartz diorite gneiss.

quartzite.

schist.

Tertiary igneous rocks.

Miocene rocks

Moraine, medial, Bull Lake.

Morrison Formation

Muscovite, potassium-argon age.

$$
\text { N, } \mathbf{O}
$$

Neiman, Harriet, spectrographic analyst Neoglaciation features.

Nomenclature, rocks in study area Nugget Sandstone, Bell Springs Member

lower part, geologic history

Oligocene rocks, Elkhead Mountains........ Olivine basalt, potassium-argon age.

Overthrusts, early Tertiary.

\section{$\mathbf{P}$}

Paleocene rocks, Elkhead Mountains........

Paleozoic Era.

Park Range

Parker, C. L., standard-rock analyst......

Pegmatite..

Phenocrysts, principal minerals

Pine Butte Member, Sundance Formation

Pinedale Glaciation, age.

Pliocene rocks.

Pliocene (?) rocks..

Ponds in area, origin

Popo Agie Formation Brynt Draw Member, fossils geologic history. Lyons Valley Member, correlation....

Porphyry, hydrothermal alteration intrusions at Hahns Peak intrusions in Precambrian rocks.......

Potassium-argon age, Precambrian rocks Precambrian highland, erosion surface, Park Range.

Precambrian rocks, altered gneiss amphibolite amphibolite complex

\section{Precambrian rocks, altered} gneiss - Continued

augen gneiss.

biotite gneiss

dark quartz.

felsic gneiss

felsic gneiss complex.

garnet-epidote skarn.

metaconglomerate

pegmatite.

porphyry intrusions

potassium-argon ages

quartz diorite gneiss

quartzite

relation to structural highs

schist.

structural features

Precipitation

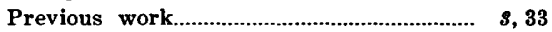

\section{$\mathbf{Q}, \mathbf{R}$}

Quartz, massive, lenses in altered gneiss Quartz diorite gneiss. See Gneiss, quartz diorite.

Quartzite.................................................... 14, 32

Quaternary deposits................................... 42

Radiometric dating.

18,55

Red Peak Formation.................................... 18, 55

Red siltstone member, Chinle Formation 24

Redwater Shale Member, Sundance Formation.

26,28

Regional unconformity, Bell Springs Member, Nugget Sandstone.

Rocky Mountains, uplift, Laramide Revolution

Routt County, location of quadrangles.

Rubidium-strontium age, Precambrian rocks.

$\mathbf{S}$

Sample localities, metamorphic rocks....... 11 Tertiary igneous rocks.......................... $s 9$

Sanidine, potassium-argon age.................... 41

Scaphites whitfield, Mancos Shale............ 31

Scapolite, potassium-argon age................. 17

Schist......................................................... 13, 32

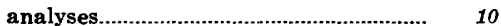

sample localities........................................ 11

Sears, G. W., spectrographic analyst....... 38

Silification, breccia pipe... 56

Skarn, garnet-epidote, mineral composi-

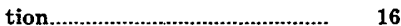

Slope-wash deposits (colluvium) ............. 45, 57

Smith, H., chemical analyst........................ 10, 38

Snowfall, average annual......................... 5

Steamboat Lake graben................................ 50, 57

Stream diversions, artificial....................... 54

Structure........................................... 46

horst and graben.......................................... 49

Precambrian rocks................................. 7, 76

Sundance Formation

age.......................................................... 19

Canyon Springs Sandstone Member 26
15

5

8

5

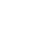

6

1

1

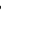

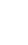

8

6

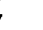

.

4

6

5

26 
Sundance Formation - Continued

geologic history

Pine Butte Member

Redwater Shale Member.

Windy Hill Sandstone Member

\section{$\mathbf{T}$}

Tectonism, periods.

Temperatures, average.

Terrace gravels.

Tertiary rocks, igneous, alteration igneous, analyses.

Texture, amphibolite.

augen gneiss.

biotite gneiss

felsic gneiss

felsic gneiss complex

quartz diorite gneiss

quartzite

schist.

Thrust faults.

Till

Topography
Page $\quad$ Page

55 Trees, common varieties in area................ 6 development of "knees".........................

Triassic rocks............................................... 18

Troublesome Formation...............................

$$
\mathbf{U}, \mathbf{V}
$$

Uplift, Hahns Peak horst.............. 49, 50, 56, 57 Park Range, geologic history............ 56

Vaugonia conradi, Pine Butte Member, Sundance Formation.

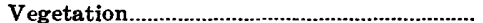

Volcanic rocks, epiclastic............................ $\$ s$

$\mathbf{W}, \mathbf{X}, \mathbf{Y}$

Wastage, mass, geologic history................ 67

Windy Hill Sandstone Member, Sundance

Formation................................... 28

$\mathrm{X}$-ray analysis...................................35, 36, 37, 40

43

5, 44 Young, E. J., modal analyst...................... 10 


